\title{
La potestad sancionadora en el Derecho comparado: Reino Unido
}

\author{
Antonio José Sánchez Sáez'
}

Sumario: I. INTRODUCCIÓN. 1. El derecho administrativo en el Reino Unido. 2. La ausencia de un auténtico procedimiento administrativo en el derecho británico. 3. Las inquiries como sucedáneo de procedimiento administrativo común en el Reino Unido. A) Concepto. B) Trámites y garantías esenciales. II. LA REGULATORY ENFORCEMENT AND SANCTIONS ACT 2008 (RESA) COMO MARCO DE LA NUEVA REGULACIÓN DE LA POTESTAD SANCIONADORA EN EL REINO UNIDO.1. Contexto en el que nace la Ley: simplificación administrativa, mejora de la regulación y del ejercicio de las potestades administrativas, reducción de cargas administrativas innecesarias. 2. Los informes que dieron lugar a la RESA. A) El informe Hampton. B) El informe Macrory. 3. Significado de las expresiones regulatory function y enforcement. 4. Aplicación territorial de la RESA. 5. Estructura de la RESA. III. EL INDIRIZZO POLÍTICO DEL GOBIERNO DEL REINO UNIDO SOBRE EL EJERCICIO DE POTESTADES ADMINISTRATIVAS DE GRAVAMEN POR PARTE DE LAS ADMINISTRACIONES LOCALES: LA PARTE PRIMERA DE LA RESA (THE LOCAL BETTER REGULATION OFFICE, LBRO). IV. LA COORDINACIÓN DE LAS ADMINISTRACIONES LOCALES PARA EL EJERCICIO DE POTESTADES ADMINISTRATIVAS DE GRAVAMEN: LA PARTE SEGUNDA DE LA RESA (CO-ORDINATION OF REGULATORY ENFOR(EMENT). V. EL RÉGIMEN JURÍDICO DE LA POTESTAD SANCIONADORA RECOGIDO EN LA PARTE TERCERA DE LA RESA (CIVIL SANCTIONS). 1. La mixtificación de las infracciones y sanciones penales y administrativas en el Reino Unido. 2. Ámbito territorial de la parte III de la RESA. 3. Ámbito subjetivo de la parte III de la RESA. 4. Ámbito objetivo de la parte III de la RESA. 5. El marco sancionador en el Reino Unido desde la aprobación de la RESA: distribución de competencias en materia sancionadora. 6. La flexibilidad como objetivo principal del nuevo régimen jurídico de la potestad sancionadora en el Reino Unido. 7. Tipología de las sanciones previstas en la parte III de la RESA. A) Fixed monetary penalties. 1. Concepto. 2. Atribución de la potestad. 3. Procedimiento. 4. Su

1 Profesor Titular de Derecho Administrativo. Universidad de Sevilla. Esta investigación se integra dentro del Proyecto de Excelencia de la Junta de Andalucía titulado "Derecho público, responsabilidad, control y ordenación del territorio" (Po6-SEJ-01754). 
ejecución forzosa. 5. El juego del principio non bis in idem. 6. La preferencia temporal de las sanciones administrativas sobre las sanciones penales. $B$ ) Discretionary requirements. 1. Concepto. 2. Atribución de la potestad. 3. Procedimiento. 4. Tipos de discretionary requirements. A) Las «variable monetary penalties». 1. Concepto. 2. Ejecutoriedad y non bis in idem. B) Las «compliance notices» $O$ «compliance requirements». C) Las «restoration notices» $O$ «restoration requirements». 1. Concepto. 2. El juego del principio de non bis in idem. C) Las «stop notices». 1. Concepto. 2. El juego del principio non bis in idem. 3. Indemnizaciones procedentes en casos de daños provocados por la imposición de una stop notice inadecuada. D) Enforcement undertakings. 1. Concepto. 2. Contenido. 3. Publicidad. 4. Ejecución forzosa. 8. La recuperación de los costes en los que haya incurrido la agencia al imponer y ejecutar la sanción administrativa. 9. Las guías para el ejercicio de la potestad sancionadora. A) Las penalty guidance. B) Las enforcement guidance. 10. Requisitos de publicidad de la potestad sancionadora. 11. Medidas adicionales y suplementarias a la sanción administrativa. VI. EL NUEVO CONTROL JUDICIAL DE LA POTESTAD SANCIONADORA EN EL REINO UNIDO. 1. La creación de una suerte de jurisdicción contencioso-administrativa material británica: el First-tier Tribunal, el Upper Tribunal y la Supreme Court. A) Su organización. B) Los recursos judiciales frente a las sanciones administrativas. 1. Frente a las "fixed monetary penalties"y las "variable monetary penalties". 2. Frente a las "stop notices". 3. Frente a los "enforcement undertakings". 2. Las garantías y derechos del art. 6 CEDH (y de la human rights act 1998) aplicables al procedimiento administrativo sancionador y a los procesos judiciales frente a sanciones administrativas en el Reino Unido. VII. LA BÚSQUEDA DE LA INTERVENCIÓN ADMINISTRATIVA MÍNIMA: LA PARTE CUARTA DE LA RESA (REGULATORY BURDENS). 1. Concepto de burdens. 2. Ámbito subjetivo de la obligación de reducir, eliminar o revisar gravámenes administrativos innecesarios. 3. Acciones a adoptar. VIII. CONCLUSIONES.

\section{INTRODUCCIÓN}

En las líneas que siguen nos centraremos fundamentalmente en el estudio de la Regulatory Enforcement and Sanctions Act 2008 (RESA, en adelante), la reciente Ley del Parlamento del Reino Unido que ha venido a configurar, por primera vez en ese Estado, un Derecho administrativo sancionador ad hoc, si bien con las limitaciones que imponen su ámbito objetivo y subjetivo. Aun así, no queremos olvidar la auténtica vocación de esta investigación, el estudio comparado de los ordenamientos jurídicos británico y español, razón por la cual hemos intentado confrontar las soluciones legales que ambos Derechos dan a problemas comunes. Se explica, además, el contexto en el que nace la Ley y las medidas liberalizadoras y de simplificación administrativa que trae consigo.

Al hilo del estudio de la materia sancionadora, que conforma el núcleo esencial de este estudio, se da noticia también de las recientes reformas judiciales emprendidas en el Reino Unido, que afectan profundamente al Derecho Público. Pero antes creemos

92 necesario realizar un breve excurso sobre el estado del Derecho Administrativo en UK. 


\section{El Derecho Administrativo en el Reino Unido²}

Inglaterra, país matriz del Reino Unido, carece de Constitución escrita. No así Irlanda del Norte, que hizo de su Constitución de 1922 (reformada en 1937), un símbolo de independencia. Sin hacer mayor abundamiento, debemos enfocar esa circunstancia no como una causa sino una consecuencia del entendimiento del Derecho en Inglaterra, que se concibe más como emanación de la cultura popular, de las tradiciones y de los casos ya revisados por los Tribunales que como formalización de la voluntad jurídica de una determinada generación de personas, que, en esa inteligencia, carecería de legitimación para petrificar y vincular indefinidamente a sus sucesores.

Y la Administración y su Derecho no escapan de esa forma de ver las cosas. El origen del desapego británico por el Derecho Administrativo tiene su inicio en el período de guerras civiles que asoló Inglaterra en el s. XVII (1641-1651), que enfrentó al bando republicano de Oliver Cromwell con los monárquicos seguidores de Carlos I y de su hijo Carlos II. Esas revoluciones consagraron el principio de que la Corona no puede gobernar a sus súbditos sin su consentimiento, expresado a través del Parlamento. La furia de los revolucionarios se cebó especialmente con el Judicial Committee of the Privy Council (comúnmente Ilamada Star Chamber), que asesoraba al Monarca, pero que tenía también jurisdicción para juzgar a los Lores y al resto de la nobleza de sangre, otorgándoles indulgencia cuando, a veces, cometían delitos y desmanes, para vergüenza del pueblo3 . Desde entonces, muy influidos por la autorizada opinión del Prof. Dicey ${ }^{4}$, que denostaba el sistema francés del Droit administratif,

2 En esta investigación haremos referencia en la mayoría de las veces al derecho del Reino Unido, Estado compuesto que, como sabemos, aglutina a cuatro naciones, o, si se prefiere, a dos realidades geográficas: Inglaterra, Gales y Escocia (que conforman la mayor de las islas, Gran Bretaña), más Irlanda del Norte. Se trata de una monarquía parlamentaria cuyo jefe de Estado es la Reina Isabel II. Lo haremos así porque el Derecho emanado del Parlamento de Londres afecta a las cuatro, a pesar de que las leyes allí aprobadas, tras la descentralización política realizada tortuosamente en las últimos años, y la constitución de los Parlamentos autónomos de Belfast, Cardiff y Edimburgo, dejan espacio para un desarrollo posterior diferenciado, de manera parecida a como ocurre en España con nuestras leyes básicas estatales y las leyes de desarrollo autonómicas.

Esta investigación se enmarca dentro del Proyecto de Investigación de Excelencia de la Junta de Andalucía “Derecho público, responsabilidad, control y ordenación del territorio", Po6-SEJ-01754, dirigido por el Prof. Alfonso Pérez Moreno, con sede en el Área de Derecho Administrativo de la Universidad de Sevilla.

3 Sobre el proceso de conformación del Common Law y los orígenes remotos del Derecho Administrativo en Inglaterra, véase, in toto, el estupendo artículo de Soto Kloss, E. (1973), “¿Existe un Derecho Administrativo inglés?", en Revista de administración pública, N. ${ }^{\circ} 70$.

4 En su famosa obra An Introduction to the Study of the Law of the Constitution, publicada en 1885, el Prof. Albert Dicey, Catedrático en Oxford, muchos de cuyos postulados se consideran parte de la Constitución no escrita del Reino Unido, despotricaba contra los intentos del Gobierno de crear tribunals y cuerpos interpuestos de carácter administrativo (ad hoc bodies) entre el Parlamento y el ciudadano. En su opinión, el rule of law debía mantenerse puro de las influencias gubernamentales, centrándose en la legitimidad del Parlamento y su poder ilimitado, en la imparcialidad de los jueces y tribunales (Courts) y en el sometimiento del Gobierno al Common Law. En particular, en relación con el Gobierno, el Prof. Dicey consideraba la necesidad de limitar o eliminar la discrecionalidad de la Administración, que, a su juicio, de ma- 
cualquier intento de someter a la Corona, a los nobles, y, por extensión, a la Administración, a unas reglas y tribunales distintos a los del Common Law han sido vistos hasta hace bien poco como una distorsión de la igualdad y del rule of law'.

No obstante, en la segunda posguerra, los propios Tribunales comenzaron a acercarse paulatinamente a la idea de un Derecho Administrativo legítimo, cuando comenzaron a darse cuenta de la necesidad de que las Agencias, el Gobierno y la Administración local tuvieran un margen de discrecionalidad suficiente para manejar los maleables asuntos públicos, habida cuenta de la incapacidad del Parlamento de prever todos los casos y supuestos de hecho previsibles. Hasta entonces las leyes parlamentarias no otorgaban esas potestades de tipo discrecional, de manera que la Administración caía repetidamente en el vicio de ultra vires (lo que podría traducirse en aquel entonces como incompetencia material o falta de habilitación legal). Desde entonces hasta ahora la High Court ha ido asentando la idea de que es legítimo que exista esa discrecionalidad, que no es más que parte del deseo del Parlamento de otorgar flexibilidad a la actuación administrativa, de forma que el vicio de ultra vires ya no se entiende de manera estricta como la falta de habilitación legal parlamentaria en el actuar administrativo, sino como una actuación administrativa realizada al margen del procedimiento establecido, o en la que exista desviación de poder (bias, improper purposes), falta de motivación (irrelevant considerations), o arbitraria (unreasonably acting $)^{6}$. Esa legitimación judicial ha acabado revalorizando el Derecho Administrativo, como ciencia jurídica encargada del estudio de la Administración, de su control y de sus potestades, cada vez más parecida y homologable a la de la Europa continental.

\section{La ausencia de un auténtico procedimiento administrativo en el Derecho británico}

En el Reino Unido, a diferencia de lo que ocurre en la mayoría de los países desarrollados, y, en particular, a diferencia de otros países herederos del rule of law (como EE.UU. o Canadá), no existe una ley de procedimiento administrativo. Son varias las razones que pueden explicar esa ausencia:

\footnotetext{
nera poco realista -deberíamos decir hoy- debía limitarse a aplicar la ley como un silogismo, sin hacer valoraciones de oportunidad, del caso concreto ni ideológicas. Su segundo postulado sobre el rule of law se refería a la igualdad ante la ley, de manera que desde la persona más alta (the highest in the land, en clara referencia a los nobles o a la misma Corona) hasta el ciudadano más normal debían someterse a las mismas leyes, enjuiciadas por jueces ordinarios. Finalmente, no defendía la creación del Derecho por el Parlamento (statutes) sino la recreación de la ley ordinaria de la tierra, actualizada por las decisiones judiciales (case law, precedent), en lo que suponía una clara defensa de la Constitución no escrita del Reino Unido y una tacha también a los poderes reglamentarios de los Ministros. Vid. Alder, J. (1989), Constitutional and Administrative Law, McMillan, Londres, pp. 42-53.

5 De hecho, el Derecho Administrativo se sigue viendo por gran parte de la doctrina como una parte del Derecho constitucional, como un Derecho sectorial que regula un aspecto concreto de la Corona, cual es la Administración. Véase, por todos, Alder, J. (1989), Constitutional and Administrative Law, opus cit., p. 6.

6 Cfr. Craig, P. P. (1994), Administrative Law, Sweet \& Maxwell, tercera edición, Londres, pp. 5 y 6.
} 
- en general, la sumisión de la Administración Pública, la Corona y el sector público al Common Law, y, por tanto, la inexistencia de un régimen de exorbitancias de la Administración, que hace innecesario la aprobación de leyes de garantías para los administrados, entre ellas la ley de procedimiento administrativo;

- la importancia que, para el dictado de actos administrativos (decisions u orders), siguen teniendo los principios de la justicia natural, de la buena administración, equidad y tradición, que se comportan como mecanismos de defensa judicial de los particulares frente a la arbitrariedad y discrecionalidad de los poderes públicos;

- el decisivo papel que los tribunales del orden penal tienen en UK en la adopción o imposición frente a los administrados de lo que en España serían simplemente actos administrativos de gravamen, y que en el Reino Unido son directamente delitos (criminal offences). Hasta hace bien poco en UK no existían sanciones administrativas, habida cuenta de la ausencia de Derecho Administrativo, por lo que las infracciones se sancionaban y sancionan aún hoy en gran medida de manera penal, con multas ( fines$^{7}$, ya que en el mundo anglosajón la expresión penalties es más propia de las sanciones civiles ${ }^{8}$ ) o con cárcel. Y esto porque en la mentalidad británica era inconcebible que fuera la Administración (con su carga de subjetividad y de parcialidad) la que infligiese un "daño jurídico" legítimo a los ciudadanos, en lugar de un juez imparcial e independiente.

- Finalmente, y como razón principal, la regulación de cada procedimiento administrativo en sus respectivas leyes sectoriales ${ }^{9}$.

\section{Las inquiries como sucedáneo de procedimiento administrativo común en el Reino Unido}

\section{A) Concepto}

Todo ello ha llevado a la necesidad de encontrar alguna solución jurídica a la ausencia de un procedimiento administrativo común, que otorgue seguridad jurídi-

7 Hay cientos de ejemplos de infracciones penadas criminalmente con fines. Como ejemplo, baste recordar las multas o penas de cárcel previstas en los arts. 1,7;11,7, 19,4, etc. de la Regulation of Investigatory Powers Act 2000; o las previstas en el art. 35.3 de la Local Government Act 1988. Cada ley recoge las suyas, y son de un tipo penal abierto, del estilo "Las infracciones del Título I serán castigadas con multa de $X$ dinero o cárcel de tantos meses".

8 Se ha definido la expresión penalty como: "The infliction of some pain, suffering, loss, disability, or other disadvantage on a person by another having legal authority to impose punishment. Punishment must be legally authorised, otherwise it is prima facie tortious or itself criminal". Cfr. Walker, D. (1980), The Oxford Companion to Law, Clarendon Press, Oxford, p. 1017.

9 Así, los procedimientos administrativos estándards son: public participation, conciliation, adjudications, inquiries, inspections, licensing, prosecutions, default powers, contracting y administrative rule-making. Cada uno de ellos está regulados por distintas leyes. Por ejemplo, las prosecutions, que son formas de perseguir infracciones de las normas (offences), tienen procedimientos distintos según se infrinjan leyes de urbanismo, de transporte, etc. Cfr. Bailey, S. H., Jones B. L., y Mowbray, A. R. (1992), Cases and materiales on Administrative Law, Sweet and Maxwell, segunda edición, Londres, pp. 52-126. 
ca y predecibilidad a las decisiones públicas más importantes, y ha determinado en las últimas décadas la decantación de un procedimiento más o menos común para la realización de inquiries, expresión jurídica inglesa para la que no existe un término equivalente en nuestro Derecho Administrativo, pero que, en resumen, hace referencia a aquellos procedimientos seguidos por los Ministros y por las demás Administraciones (también la Administración local) para la toma de decisiones administrativas en las que se encuentran enfrentados un interés público y determinados intereses particulares (por ejemplo, el otorgamiento de una licencia de obras, la reparcelación de una finca, la expropiación de tierras para ejecutar una obra pública, etc.). La Ley que establece el procedimiento para la elaboración de una inquiry (Inquiries Act 2005, en adelante IA) es lo más parecido que tiene el Reino Unido a una Ley de procedimiento administrativo común, ya que en cada Ley administrativa sectorial (educación, salud pública, carreteras, empleo público, etc.) existe un procedimiento distinto para la adopción de decisiones administrativas, aunque con ciertos rasgos generales.

El origen de las inquiries puede concretarse a mediados del s. XIX. En concreto, aquéllas permitidas mediante ley (las statutory inquiries), se desarrollaron como un procedimiento de toma en consideración de intereses enfrentados entre varios individuos o entre individuos y el Gobierno, el Estado, las Agencias o la Administración local. Así, era normal recurrir a una inquiry para solventar problemas con los cerramientos de fincas, sanidad pública, accidentes producidos en vías del tren, minas, empresas, y, en general, para ponderar los intereses de todos os afectados por licencias administrativas de uso del suelo ${ }^{10}$.

El procedimiento para la realización de una inquiry era bastante similar al que seguían los Tribunales (a la vista del tradicional rol de los tribunales y jueces británicos en la determinación de los asuntos del bien común): de hecho, hasta hace bien poco se regulaban en la misma Ley (Tribunals and Inquiries Act de 1958 y de 1992) ${ }^{11}$. No obstante, en los últimos, en la línea marcada por los Gobiernos de Tony Blair y Gordon Brown, que han llevado a cabo políticas de separación del poder judicial y del poder ejecutivo (cuyo hito ha sido la abolición de la jurisdicción de los Lores y la correlativa creación de un Tribunal Supremo británico), se aprobó una Ley de Inquiries independiente, en 2005 (Inquiries Act 2005). A pesar de la importancia que tiene la formalización de una especie de procedimiento administrativo en UK a través de este instrumento, se nos hace difícil pensar en su uso como cauce para la imposición

10 Cfr. Craig, P. P. (1994), Administrative Law, Sweet \& Maxwell, tercera edición, Londres, p. 57.

11 Sobre la distinción entre tribunals y inquiries, véase Wade, W. y Forsyth, C. (2000), Administrative Law, octava edición, Oxford University Press, Oxford, pp. 889 y 890 . Mientras que las segundas revisan hechos y pruebas, los primeros sólo aplican la ley; a las segundas, además, les interesan los aspectos locales del bien común y tienen que proponer una resolución administrativa de un asunto al Ministro, mientras que los primeros toman decisiones judiciales objetivas. Pero tienen algo en común: las cuestiones de policy (ideología o política administrativa, esto es, discrecionalidad) no pueden ser discutidas ni en las inquiries ni 96 en los Tribunales. Y véase también Hawke, N. 
de sanciones administrativas, ya que, por un lado, es poco probable que en la comisión de una infracción haya terceros interesados o incluso un interés público concreto que pudiera exigir la convocatoria de un trámite de información pública (esencial en las inquiries), más allá de la inherente finalidad pública de justicia propia de la potestad sancionadora, que aboga por la defensa social frente a conductas lesivas del orden público, aunque es posible ${ }^{12}$; por otro, porque las inquiries tienen un destacado rasgo reactivo, que no se compadece con la necesidad de normalidad de las sanciones administrativas.

Nosotros, los observadores externos del Derecho Administrativo en UK, podemos considerar el procedimiento administrativo previsto en la IA para la celebración de inquiries como la sublimación de lo que, según la justicia natural, la jurisprudencia del case law y los principios del rule of law debe ser el cauce de elaboración de cualquier decisión del Poder ejecutivo, la Corona o la Administración, esté o no recogido en la Ley ${ }^{13}$. Es por ello por lo que la IA no tiene valor de norma básica, ni siquiera de aplicación subsidiaria, en el sentido que le damos en España, pues cada Ley administrativa que prevé el uso de inquiries establece un procedimiento propio (statutory inquiries). Su conocimiento, para nosotros, sí que tiene un importante valor didáctico, como un sucedáneo de procedimiento común (broadly uniform procedure ${ }^{14}$ ) en la medida en que nos enseña los trámites esenciales y las garantías que en el Reino Unido actual debe tener cualquier procedimiento administrativo concreto (lo que en el Reino Unido se denomina un specimen procedure, lo que incluye, por tanto, cualquier procedimiento de imposición de sanciones administrativas, al margen del ámbito objetivo de aplicación de la RESA) ${ }^{15}$.

\section{B) Trámites y garantías esenciales}

Los trámites y garantías del procedimiento previsto en la IA han sido completados por las reglas dictadas por el Lord Chancellor, uno de los más altos funcionarios al

12 De todas formas, la propia IA permite a un Ministro usar una inquiry cuando lo estime pertinente, de manera discrecional, siempre que se cumpla alguno de los siguientes dos requisitos: la existencia de hechos o sucesos que hayan causado o que pudieran causar preocupación pública, o la existencia de una preocupación pública acerca de hechos que pudieran haber ocurrido (art. 1 IA). El único límite al empleo de este instrumento procedimental es su inadecuación para exigir reclamaciones de responsabilidad (art. $2 \mid \mathrm{A})$.

13 Trasncribo literalmente las acertadas palabras de Wade al respecto: "The statutory procedure is usually only a framework, within wich the principles of natural justice operate to fill in details and ensure that fair procedures are followed". Cfr. Wade, W. y Forsyth, C. (2000), Administrative Law, octava edición, Oxford University Press, Oxford, pp. 938 y 944.

14 Sobre esta especie de procedimiento administrativo común y la función de las inquiries como forma rutinaria de toma de decisiones administrativas, con diferentes actos administrativos de trámite, véase Alder, J. (1989), opus cit., pp. 280-284.

15 No obstante, el procedimiento previsto en la Inquiries Act de 2005 puede aplicarse a las inquiries previstas en esas otras leyes administrativas si así lo decidiera el Ministro y los interesados (art. 15 IA), en atención a las leyes aprobadas como desarrollo del art. 9 de la Tribunals and Inquiries Act de 1992, lo que 
servicio del Gobierno, como asesor personal del Primer Ministro y que, hasta hace poco, era el equivalente a nuestro Ministro de Justicia ${ }^{16}$ (The Inquiry Rules 1838/2006, de 11 de julio ${ }^{17}$ ), y son los siguientes:

a) La obligación de imparcialidad, equilibrio, expertización e independencia de los miembros del órgano administrativo (panel) encargado de proponer la adopción de la decisión a la autoridad administrativa de rango político (generalmente el Ministro), arts. 87 y $11 \mathrm{IA}$;

b) la obligación de abstención de alguno de ellos cuando concurra algún interés directo en el asunto o alguna relación estrecha con alguna de las partes interesadas (art. 9 IA);

c) la protección de los miembros del órgano frente a reclamaciones, si éstas derivan del correcto ejercicio de su cargo (art. 37 IA); (art. 13 IA);

d) la posibilidad del Ministro de suspender el procedimiento en casos tasados

e) la fase de alegaciones (hearings) y/o de información pública (public hearings o public inquiries), que, aunque no está prevista expresamente en la IA, debe darse con carácter necesario cuando lo estime necesario el titular del órgano ${ }^{18}$;

f) la fase de prueba, en la que se pueden tomar juramentos por el titular del órgano (chairman), conforme a las órdenes aprobadas por el Lord Chancellor o, en su defecto, conforme a las reglas tradicionales de justicia y eficiencia (fairness, avoid unnecessary costs) que dicte el titular del órgano; entre las pruebas admitidas, están las documentales y las testificales; arts. 17 y 21 IA. Cada prueba practicada debe ser puesta a disposición de la otra parte, conforme al principio de fairness y de la natural justice;

g) en las inquiries, a la vista de los intereses públicos implicados, es obligatorio el acceso del público a todos los trámites, incluso de la prensa, con los límites que marcan la protección de la intimidad o de la seguridad. Se trata ésta de una garantía que no es propia de los procedimientos sancionadores, a la vista de las

prueba la vis attractiva de este procedimiento formalizado. Sobre el procedimiento común de las statutory inquiries véase Cfr. Craig, P. P. (1994), opus cit., pp. 163-168.

16 El Lord Chancellor, actualmente el Sr. Jack Straw, perdió sus principales funciones tras la aprobación de la Constitutional Reform Act 2005, cuyo proyecto incluso pretendía abolir esta arcaica figura. Ya no preside la Cámara de los Lores ni tampoco es la cabeza del poder judicial en Inglaterra y Gales, ya que está sometido al Ministro del ramo, el Lord Chief Justice.

17 Y sus homólogas The Inquiries (Scotland) Rules 560/2007, para Escocia.

18 Cfr. Wade, W. y Forsyth, C. (2000), opus cit., p. 941. 
escasas implicaciones para los intereses públicos que acarrean, como se ha dicho antes; arts. 18 y 19 IA;

h) la dación de cuentas (report), en la que se incluye la propuesta de resolución que se le hace al Ministro, de cuya copia debe dejarse constancia ante el Parlamento británico o ante la Asamblea nacional, en su caso, una vez instruido el procedimiento (art. 24 IA); este informe debe ser notificado también a cada interesado (art. 17 de las Inquiry Rules 1838/2006); este report no es vinculante para el Ministro, que incluso puede rechazar todas las pruebas realizadas;

i) la revisabilidad de las decisiones adoptadas por el Ministro sobre la base de una inquiry, o por los miembros del órgano que la ha llevado a cabo: el afectado dispone de 14 días para recurrir esas decisiones administrativas ante los Tribunales (art. 38 IA); sólo los interesados que hubiesen comparecido en la inquiry tienen legitimación (locus standi) para revisar la decisión, como person aggrieved ${ }^{19}$;

j) el pago de las costas derivadas durante el procedimiento administrativo de celebración de la inquiry corre a cargo del Ministro, salvo el pago de la práctica de las pruebas propuesta por la parte interesada;

k) Las Inquiry Rules 1838/2006 regulan los medios de notificación ${ }^{20}$, representación legal ${ }^{21}$, testimonios (oral evidence) ${ }^{22}$, la posibilidad de emitir advertencias (warning letters) a aquellos administrados que no cumplan las normas y que puedan causar un daño real o potencial al interés público ${ }^{23}$, y la obligación de registrar el completo procedimiento de realización de la inquiry ante el Ministerio competente o en el Registro de procedimientos administrativos (National Archives), a decisión del Ministro24, y el pago de compensaciones económicas por los gastos realizados por los interesados durante la tramitación del procedimiento (awards) ${ }^{25}$. Como regla general, las costas se suelen pagar a los interesados que resultaran vencedores en la inquiry.

19 Cfr. Wade, W. y Forsyth, C. (2000), opus cit., p. 962.

20 Entrega en mano, correo postal de primera clase, fax, e-mail. Al igual que en nuestro país, el uso del e-mail sólo será válido cuando la persona interesada previamente lo haya manifestado (art. 3.2 de las Inquiry Rules 1838/2006).

21 Que debe otorgarse a un abogado, cuando el interesado (core participant) así lo decida (art. 6 de las Inquiry Rules 1838/2006), cabiendo incluso que dos o más interesados con intereses similares sean representados por el mismo abogado, bajo petición del titular del órgano administrativo que lleva a cabo la inquiry. El otorgamiento de representación legal en un procedimiento administrativo es algo que puede extrañar al jurista español, pero perfectamente normal en el Reino Unido, en el que no existe una nítida separación entre fase administrativa y contencioso-administrativa.

22 Cfr. art. 10 de las Inquiry Rules 1838/2006.

23 Cfr. arts. 14 y 15 de las Inquiry Rules $1838 / 2006$.

24 Cfr. art. 18 de las Inquiry Rules 1838/2006. A nivel nacional, ese Registro varía: the Keeper of the Records en Escocia y el Public Record Office en Irlanda del Norte.

25 Cfr. arts. 19-34 de las Inquiry Rules 1838/2006. Estos awards son otorgados por el titular del órgano administrativo que lleva a cabo la inquiry, a los interesados que participaron en ella por la pérdida de tiempo que les ha supuesto ducha participación o por los gastos que les haya supuesto (art. 41 IA). 


\title{
II. LA REGULATORY ENFORCEMENT AND SANCTIONS ACT 2008 (RESA) COMO MARCO DE LA NUEVA REGULACIÓN DE LA POTESTAD SANCIONADORA EN EL REINO UNIDO
}

\author{
1. Contexto en el que nace la ley: simplificación administrativa, mejora \\ de la regulación y del ejercicio de las potestades administrativas, reducción \\ de cargas administrativas innecesarias
}

La Regulatory Enforcement and Sanctions Act (en adelante RESA) fue sancionada el 21 de julio de 2008, aunque entró en vigor el 1 de octubre de 2008, excepción hecha de algunas de sus previsiones de la Parte Segunda (que lo hicieron anticipadamente el 6 de abril del mismo año) y está suponiendo una auténtica revolución en el hasta ahora poco administrativizado Derecho del Reino Unido. Cualquier traducción literal de su enunciado resultaría poco afortunada, porque exigiría explicar inmediatamente la terminología empleada en el mundo jurídico anglosajón, tan distinto al nuestro en sustancia y forma, por lo que nos contentaremos con decir, por ahora, que se trata de una Ley que tiene por objetivo mejorar la calidad de la aplicación de las leyes por parte de las Administraciones locales estatales del Reino Unido, dotándolas, además, de una auténtica potestad sancionadora general de carácter administrativo, de la que carecían $^{26}$.

26 La palabra enforcement es un término jurídico anglosajón que se refiere a la ejecución o aplicación de las normas por parte de las Administraciones o del Gobierno, esto es, a hacerlas cumplir. No hablamos aquí propiamente de un privilegio de ejecutoriedad, que no existe en el Derecho británico, sino de su estadio previo: la obligación y facultad de aplicar las normas a las personas físicas y jurídicas, aplicación que, para el caso de esta ley, implica el ejercicio de potestades administrativas de gravamen (reglamentaria, de autorización, sancionadora, etc.) y que, por tanto, acarrea obligaciones para dichas personas, e incluso, la imposición de sanciones administrativas o penales como consecuencia de su incumplimiento. Por tanto, las enforcement functions de las Agencias o Administraciones británicas no son más que un equivalente, salvadas las distancias, de nuestras potestades administrativas, y los regulators son las Administraciones y Agencias encargadas de aplicar la regulación. Véase también la interpretación del término, aunque no en un sentido tan jurídico-formal como el que damos nosotros, que da Betancor, A (2009), "Derecho Administrativo sancionador en el sistema jurídico británico: Regulatory Enforcement and Sanctions Act 2008”, RGDA, 19, p. 13: "Se trataría, en consecuencia, de la genérica o específica habilitación para ejecutar y controlar la ejecución de lo dispuesto en las leyes y, en particular, todo lo relacionado con las conductas consideradas como infracción a los efectos de la imposición del castigo que corresponda, incluido el criminal o penal (art. 71.1).".

La RESA define enforcement action en su art. 28.5 como cualquier acción referida a asegurar el cumplimiento mediante la imposición de restricciones, requisitos o condiciones en caso de infracción, o supuesta infracción, de una restricción, requisito o condición previamente establecida; o cualquier acción tomada para la imposición de cualquier sanción (administrativa o penal) en relación con una actuación u omisión; o cualquier acción tomada para adoptar un remedy (acción judicial) otorgado mediante ley, en relación con una acción u omisión. En la Parte Tercera de la RESA, la parte dedicada a las infracciones y sanciones administrativas, en su art. 71, se dice que la expresión "enforcement function”, en relación con una infracción, implica cualquier función en la que se adopta cualquier tipo de medida con la finalidad de, o en conexión con, la imposición de cualquier sanción, penal o de otro tipo (administrativa) en un caso en el que se ha cometido una infracción.

La expresión ha sido desarrollada por la Orden 665/2009, titulada “REGULATORY REFORM-The Coordination of Regulatory Enforcement (Enforcement Action)”, que la define de una manera más precisa, y que, en general, se refiere al ejercicio de lo que en nuestro Derecho podríamos Ilamar potestades adminis- 
La RESA se incluye dentro de la política legislativa del Gobierno laborista denominada "Better Regulation Agenda", y, por tanto, trae causa directa de la Legislative and Regulatory Reform Act de 2006 (en adelante, LRRA), una Ley cuyo principal objetivo es reducir las cargas administrativas (burdens) existentes en la regulación británica, y que impiden un mayor despegue económico del sector empresarial, al tiempo que promover entre las Administraciones y Agencias británicas una serie de principios de cara a hacer cumplir las normas (enforcement), como se verá más adelante, pero que están dirigidos a reducir la intervención administrativa a través de potestades de policía a aquellos casos en que sea estrictamente necesaria, algo que, por cierto, es una preocupación común a todo el Derecho anglosajón ${ }^{27}$.

Como veremos más adelante, toda la RESA tiene esa misma intención de fondo (reducir las cargas y gravámenes administrativos) en cada una de sus partes, de manera indirecta, bien estableciendo un organismo público encargado de esa función a nivel local, bien creando un sistema de sanciones administrativas sobre la base del principio de proporcionalidad, o de manera directa, estableciendo un deber general para las Administraciones Públicas de no imponer gravámenes administrativos innecesarios. En este sentido, resulta igualmente destacable dentro de esa política el Código de buenas prácticas de las Agencias (Regulators' Compliance Code: Statutory Code of Practice for Regulators), que veremos más adelante, y cuya regulación inicial se encontraba en los arts. 22 y 23 de la LRRA.

La tarea de reducción de las cargas administrativas en UK es una obligación proveniente de la Estrategia de Lisboa de 2001, aunque ha sido la experiencia de

trativas de policía, aunque con las especificidades propias del Derecho de UK, y de la RESA en particular. Así, se considera como tal la emisión de cualquier comunicado escrito indicándole a la empresa o persona jurídica que se van a adoptar medidas dentro de un período determinado de tiempo, a menos de que la misma actúe de la forma en que se indica para evitarlo (cumpliendo las normas, evidentemente); o la emisión de una orden de interrupción (stop notice) del art. 46.2 RESA; o de una orden de prohibición (prohibition notice) previstas en algunas leyes sectoriales que se enumeran; o de una orden de remoción (abatement notice) del art. 80 de la Environmental Protection Act de 1990; o de una orden de prohibición en casos de emergencia (emergency prohibition notice), de otras tantas leyes; o la imposición de una orden de mejora (improvemement notice) en relación a determinadas leyes enumeradas; el inicio de cualquier medida tendente a la averiguación de un delito (prosecuting); el inicio de cualquier proceso por cualquier tribunal creado mediante ley; o la imposición de cualquier sanción en relación con actuaciones u omisiones, entendiendo sanción aquí la definición amplia que de la misma da la RESA, que incluye desde multas (fines) a otras órdenes administrativas que implican gravámenes y/u obligaciones en las personas destinatarias (Discretionary requirements, stop notices, o enforcement undertakings).

27 También el Gobierno Australiano ha comenzado un proceso de reforma legislativa para reducir las cargas administrativas innecesarias impuestas por su regulación, inflacionada -sic- en las últimas dos décadas debido a las presiones sociales, ambientales y de los consumidores. La terminología que se emplea es la misma que en el Reino Unido: anquilosamiento de la regulación, necesidad de hacer un traje normativo a medida de las PIMEs (tailored regulation), que son las que menos recursos tienen para cumplir con esa regulación y más trabajo y riqueza devuelven al país, la eficacia de la autorregulación de los sectores empresariales e industriales para autoimponerse sanciones efectivas, etc. Vid. AUSTRALIAN GOVERNMENT (2006), Rethinking Regulation. Report of the Taskforce on Reducing Regulatory Burdens on Business, enero 2006. Este proceso se ha traducido en la reforma de varias leyes sectoriales, como la Aged Care Act 1997, la Migration Act 1958 o la Crimes Act 1914. 
países como Bélgica, Holanda y Reino Unido la que ha inspirado su desarrollo a través de la Comunicación de la Comisión al Consejo, al Parlamento Europeo, al Comité Económico y Social Europeo y al Comité de las Regiones, de 24 de enero de 2007, «Programa de Acción para la Reducción de las Cargas Administrativas en la Unión Europea» [COM (2007) 23 final). En esta Comunicación la UE se propone el objetivo de reducir las cargas administrativas en cinco años (2012) en un 25\% para toda la $\mathrm{UE}^{28}$.

La "Better Regulation Agenda" se ha corporeizado en la "Better Regulation Executive”, una nueva Sección del Ministerio de Negocios, Empresa y Reforma normativa [Department for Business, Enterprise and Regulatory Reform (BERR)], que conforma una política horizontal a aplicar a todo el Gobierno del Reino Unido y a su Administración Pública, cuyos objetivos principales son:

- aconsejar a los Ministerios sobre el diseño de la nueva normativa que se vaya a aprobar (reglamentos, órdenes y demás normativa delegada, es decir, statutory instruments) y la forma en que los administrados afectados deben participar en su elaboración, y explicárseles posteriormente;

- aconsejar a los Ministerios y a las Agencias administrativas estatales sobre cómo simplificar y modernizar la normativa existente;

- aconsejar a los Ministerios y a las Agencias estatales y locales sobre cómo cambiar el enfoque administrativo sobre la base del principio de proporcionalidad o de coste-beneficios (risk-assessment).

28 La Comisión ha identificado once sectores en los que las cargas administrativas pueden reducirse en 1.300 millones de euros. Los Estados miembros también deberán tomar decisiones que permitan reducir los costes, puesto que una parte importante de los mismos proviene directamente de las legislaciones nacionales y regionales. Para alcanzar esos objetivos, la Comisión propone que se elaboren unos principios comunes a fin de reducir las cargas administrativas, a saber: reducir la frecuencia de las declaraciones obligatorias a los niveles mínimos necesarios; verificar que no se impone varias veces la misma obligación de información; promover la recogida de información a través de Internet; reducir las exigencias impuestas a las pequeñas y medianas empresas, e introducir umbrales para los requisitos de información; centrarse específicamente en los operadores más expuestos a los costes administrativos en determinados sectores; reducir o suprimir los requisitos de información impuestos en relación con exigencias legislativas que hayan desaparecido o que entretanto hayan sido modificadas; y facilitar una aclaración sobre aquellos actos legislativos complejos que pudieran ralentizar la actividad empresarial. La Comisión invitaba a los Estados miembros a que concluyan su ejercicio de medición en 2009 y a que fijen objetivos de reducción de las cargas administrativas a escala nacional a más tardar en octubre de 2008. Sugiere asimismo al Parlamento Europeo y al Consejo que adopten lo antes posible las medidas relativas a los ámbitos prioritarios. Por último, la Comisión informará periódicamente sobre los progresos obtenidos en lo que respecta a la aplicación del Programa.

Antes de esa Comunicación se han ido adoptando otras sobre el mismo tema, como la Comunicación $\operatorname{COM}(2005) 535$ "Implementing the Community Lisbon programme: A strategy for the simplification of the regulatory environment" o las Comunicaciones sobre "Cargas administrativas" COM(2007)90 -COM(2007) 91- $\operatorname{COM(2007)23;~o~sobre~la~"Revisión~estratégica~del~programa~'Legislar~mejor”"~COM(2006)~689;~o~el~}$ “Primer Informe de Progreso sobre la Estrategia de simplificación del entorno normativo" COM(2006)690 final. 
La enseñanza central de esta política es instruir a las Administraciones británicas para que todas sus funciones y, paladinamente, la potestad reglamentaria y las potestades de policía (entre las cuales hay que mencionar de manera principal la potestad sancionadora) se rijan por estos cinco principios: transparencia, responsabilidad, proporcionalidad, coherencia (consistency) y necesariedad (intervenir sólo en aquellos casos en que sea necesario). La Better Regulation Agenda se compone de varias políticas sectoriales, una de las cuales es la que ocupa buena parte de la RESA, la reforma de la normativa (regulatory reform ${ }^{29}$ ), que, a su vez, se divide en varias tareas distintas ${ }^{30}$.

Este proceso simplificador es muy propio del mundo anglosajón, que siente tanto apego por las ideas de libertad y libre competencia, como animadversión por todo lo que signifique legislación, regulación y control administrativo ${ }^{31}$. Pero

29 Las otras tres son la Consultation Guidance (guías y consejos), la Inspection and Enforcement (inspección y ejecución de las normas), y la dedicada a Policy (políticas públicas).

30 Esas tareas son: Consulting Our Customers, Reducing Cost for Business, Protecting Consumers. Improving Health \& Safety Regulations, Improving Compliance among Businesses, Simplifying EU Legislation, Planning Review y Review of guidance provision. De su coordinación se encargó la Better Regulation Commission hasta enero de 2008, y, desde entonces, su tarea la realiza la Risk and Regulation Advisory Council, que tiene por misión aconsejar sólo aquella regulación que sirva para hacer frente a actividades privadas realmente arriesgadas para el interés general. Según este organismo, falsas percepciones de los riesgos que esas actividades pueden ocasionar a la sociedad traen como consecuencia una hipertrofia de normas que acaba siendo vista por la sociedad como asfixiante. En su reciente Informe, este organismo considera que a veces, por culpa de varias empresas incumplidoras, el Gobierno acaba aprobando normas que acaban afectando a todo el sector en general, lo que resulta desproporcionado. Cfr. RISK AND REGULATION ADVISORY COUNCIL (2009), Response with responsibility. Policy-making for public risk in the 21st century, mayo 2009, p. 4. Este Informe, en el que, como en casi todos los de la política gubernamental Better Regulation trata más de cuestiones de Ciencias de la Administración que de Derecho Administrativo en sí mismo, se centra más en la policy que en la Administration, e intenta cambiar "la aversión al riesgo de la política administrativa" (p. 18), una forma muy eufemística de querer imponer la desregulación o la no regulación de sectores en los que puede existir riesgo de incumplimientos por parte del sector privado, justificándose en la desproporción que ello supone cuando son pocos los incumplidores. La verdad es que enfocar la regulación o la intervención administrativa con este prisma es algo inimaginable en nuestra Administración patria, e inconveniente, a mi juicio, porque se llegaría al extremo de no regular más que los sectores completamente incumplidores, dejando una excesiva libertad de actuación a las empresas a costa de un sacrificio de los intereses generales.

31 En su Informe anual de 2008, titulado con toda intención “Making it simple”, el Gobierno británico, por boca del titular del Ministerio para la Reforma Normativa, Stephen A. Carter, presenta su política normativa con palabras muy alejadas de la técnica política, casi pedagógicas, que buscan instruir al pueblo británico sobre lo importante que es la regulación (“qué sería nuestro mundo sin normas de tráfico o sin normas que impidieran a los niños tener que trabajar?”, dice), para a continuación exponer que la normativa debe tener el doble papel de proteger los intereses generales y de incentivar el crecimiento económico, justificando el proceso de simplificación y desregulación emprendido. A los ojos de un jurista continental como el que escribe, todo se presenta con un lenguaje tan básico y naif que revela sin ambages la precaria experiencia del mundo anglosajón con la Administración y su regulación, algo que sería impropio en un país como el nuestro, tan acostumbrado desde nuestra Constitución al papel central de la Administración como motor garantizador de la igualdad, libertad, desarrollo económico de la sociedad, pero que en el Reino Unido siempre ha detentado la sociedad misma (en lo que podría denominarse como principio de subsidiariedad social). Cfr. H.M. Government (2008): Annual Review 2008, Making it simple, Londres, p. 3. En opinión del Ministro, reduciendo las cargas y gravámenes administrativos que se imponen al sector privado se pretende que las empresas "se centren en lo que realmente es importante para ellas": hacer 
con esta política estatal no se trata sólo de plasmar en la regulación e intervención administrativa la esencia democrática del pueblo británico, no debemos ser ingenuos, sino de remover los obstáculos administrativos hasta el límite de lo mínimamente exigible, con la intención de hacer competir a sus empresas y negocios desde una posición de superioridad en relación con el resto de la UE y de nuestro mundo globalizado32. La propia Memoria Económica de la RESA insiste en este análisis ${ }^{33}$.

Y no es casualidad que esta política británica de fomento económico del sector privado mediante la reforma y simplificación de la normativa administrativa sea perfectamente convergente con la misma política comunitaria de simplificación normativa, subsidiariedad y reducción de cargas administrativas, que lleva produciéndose en la UE desde hace más de diez años, y cuyo estandarte actual es la eufemísticamente denominada Directiva de servicios, que está provocando un auténtico terremoto en el enfoque administrativo continental de las licencias y autorizaciones impuestas al mundo económico 34 .

\section{Los Informes que dieron lugar a la RESA}

Siguiendo la tradición parlamentaria británica, en el que muchas leyes son consecuencia de informes técnicos de profesores, parlamentarios o funcionarios de alto

dinero, el ánimo de lucro. Las medidas simplificadoras van desde la simplificación de procedimientos para otorgar licencias de juego y de venta de alcohol, hasta la sustitución de las notificaciones escritas por las electrónicas, pasando por medidas de gestión del personal administrativo, etc.

32 En ese Informe anual, el Gobierno se plantea como objetivo económico principal de su Regulatory Reform Agenda que para finales de 2010 se haya ahorrado a las empresas y al sector público la cantidad de 3,4 billones de libras, una cantidad desorbitada que habla claramente de la profundidad de las políticas liberalizadoras y simplificadoras que se están adoptando. Para ello el Gobierno ya ha aplicado más de 240 medidas distintas.

33 Considera que la aplicación de las nuevas sanciones administrativas previstas en la Parte Tercera de la RESA va a suponer un ahorro anual de 1.132 millones de libras, que se reparten de la siguiente forma: ahorro de 88,2 millones de libras para el sector empresarial privado, de 38,8 millones de libras para el sector público, ingresos de 12 millones de libras para el Consolidated Fund (cuenta bancaria del Gobierno inglés en la que se ingresan los importes cobrados en forma de sanciones administrativas) y un ahorro de 6,1 millones de libras para el sistema judicial británico. La reducción de cargas administrativas en las cinco grandes Agencias estatales enunciadas en su Parte Cuarta supondrán un ahorro de hasta 5,2 millones de libras anuales, y, en total, el ahorro anual medio que se estima suponga la aprobación de la RESA es de entre 1.358 y 2.759 millones de libras. Cfr. BERR (2008), DEPARTMENT FOR BUSINESS ENTERPRISE AND REGULATORY REFORM, Impact Assessment: the Regulatory Enforcement and Sanctions Bill, mayo de 2008, Londres, pp. 3-5 y 24.

34 En su Informe anual de 2008, el Gobierno dice "haber persuadido a la UE para que acometa una reducción de su propio $25 \%$ de cargas y gravámenes administrativos”, p. 4. El Gobierno británico se ufana de haber convencido a la UE en esta materia, cosa no muy difícil, a mi juicio. Véase al respecto los razonamientos y complicidades de ambas políticas en H.M. Government, Making your live simpler. Simplifications plans. A summary, pp. 7 y 45-48. Ese mismo porcentaje es el que trata de reducir el Gobierno británico a finales de 2010, con la intención de llegar a ser el país del mundo en el que más "fácil” sea, desde un punto de vista administrativo, abrir y mantener una empresa. Otro de sus compromisos es reducir los datos personales (formularios) que se solicitan a los administrados (p. 8). 
rango, la RESA lleva a la práctica las recomendaciones contenidas en los siguientes Informes:

- El Informe Hampton ${ }^{35}$, titulado Reducing Administrative Burdens: Effective Inspection and Enforcement ("Reduciendo la burocracia: inspección y ejecución efectivas"), publicado en marzo de 2005.

- El Informe Macrory ${ }^{36}$, titulado Regulatory Justice: Making Sanctions Effective ("Justicia reguladora: haciendo efectivas las sanciones"), publicado en noviembre de 2006 y

- Un Informe del Gobierno, titulado Next Steps on Regulatory Reform ("Los siguientes pasos sobre la reforma de la regulación”), publicado en julio de 2007.

\section{A) El informe Hampton}

El Informe Hampton tuvo su origen en los Presupuestos de 2004, en los que el Lord Chancellor le solicitaba un Informe sobre la manera de reducir y coordinar los gravámenes impuestos por los reguladores (Agencias) al mundo empresarial privado. En esos Presupuestos, el Gobierno se comprometía a establecer un marco legislativo a aplicar a las Agencias y demás Administraciones para reducir progresivamente las medidas de policía (licencias, autorizaciones, gravámenes, etc.) que se imponen a las empresas y agentes económicos, con la intención de liberalizar y desregular adecuadamente la intervención administrativa en la economía, favoreciendo así la libre competencia y la competitividad de las empresas británicas en su propio mercado, aunque sin comprometer los estándares de la regulación ni la protección ambiental, la protección de los consumidores o los trabajadores de las empresas $^{37}$.

El Informe Hampton criticaba abiertamente la descoordinación de las Administraciones locales, que, al no comunicarse las unas con las otras a la hora de controlar la actividad comercial y empresarial, conllevaba una reduplicación de los controles administrativos, de la solicitud por varias Administraciones del mismo tipo de información e incluso, de instrucciones contradictorias para los agentes económicos.

35 Sir Philip Hampton es un reconocido auditor y asesor empresarial que ha copado algunos de los cargos privados más importantes del Reino Unido, en sectores como el del gas, petróleo, hipermercados o finanzas internacionales. Desde principios de 2009 es el Director del Banco Real de Escocia.

36 Richard Macrory es uno de los más reputados Profesores de Derecho Ambiental de la Universidad británica, director de organismos ambientales y centrado, en particular, en el tema del cambio climático. Miembro de la Royal Commission on Environmental Pollution entre 1992 y 2003 , y miembro también de la Environment Agency in England and Wales entre 1999 and 2004. Es editor en jefe de la prestigiosa Revista Jurídico-Ambiental Journal of Environmental Law. En marzo de 2008 fue nombrado Consejero honorario de la Reina.

37 La siguiente frase es expresiva de ello: "Our regulatory system has the pivotal role in resolving the regular conflict between prosperity and protection". 
En general, propone la reducción de la intervención administrativa para aquellos negocios que cumplan con la normativa ${ }^{38}$, por ejemplo, no realizando inspecciones sobre las empresas cumplidoras ${ }^{39}$, ni solicitándoles más información de la necesaria, a diferencia de lo que debería ser la actitud de la Administración con las empresas que se encuentren en más riesgos de cometer infracciones, sobre las que el Informe considera perfectamente legítimo imponer mayores cargas y gravámenes administrativos. Sobre la base de la teoría del riesgo, aconseja a los entes locales y Agencias solicitar menos información y realizar menos inspecciones en aquellos negocios menos peligrosos para la sociedad, y reconducir el capital humano y económico ahorrado por esas Administraciones en relación con esos negocios menos arriesgados a asesorar a los negocios más arriesgados sobre cómo cumplir con la normativa y a evitar, por tanto, la comisión de infracciones. Aparte de una general reducción de las formas de la intervención administrativa, el Informe Hampton aconseja unificar los impresos de petición de información, y refundir en siete Agencias generales una parte muy importante de las que ya existen con fines muy concretos (treinta y una, para ser exactos $)^{40}$.

\section{B) El Informe Macrory}

Nos interesa más para nuestro estudio el Informe Macrory, que hizo numerosas recomendaciones sobre cómo dotar a las Agencias de un conjunto de herramientas flexibles con las que poder sancionar a las empresas incumplidoras de las leyes, y cuyo uso había quedado pergeñado en el Informe Hampton, como parte integrante de la actividad administrativa de las mismas. El Informe parte del hecho de que mu-

38 Es un ejemplo de desregulación selectiva, también llevada a cabo en Alemania, por ejemplo, dentro del programa ambiental EMAS por los Länder de Bavaria, Sajonia y Rhin del Norte-Westphalia. Lo interesante es que dichas provisiones han sido desarrolladas a través de acuerdos voluntarios suscritos entre el Gobierno estatal y las empresas adheridas, y parten de la base legal del principio de "equivalencia funcional" ( funktionale Äquivalenz) entre las normas aplicables y las medidas voluntariamente adoptadas por las empresas, siempre que, aunque no sean absolutamente idénticas, tengan parecido nivel de objetivos y calidad. Este feliz principio, que en español podríamos llamar de intercambiabilidad de las formas jurídicas, supone una relajación del principio de legalidad en las formas, consiguiéndose mantener pura su esencia sustancial. Cfr. Sánchez Sáez, A. J. (2005), Los convenios de colaboración para la protección del medio ambiente, IAAP, Sevilla, pp. 630-631.

39 En nuestro país se realizan inspecciones aleatorias, no sólo a las empresas incumplidoras. Es una paradoja que la Administración británica sólo quiera inspeccionar a las empresas sin historial infractor, ya que es precisamente la inspección la que permitiría destapar infracciones ocultas o en ciernes. El Reino Unido está muy obsesionado con las inspecciones administrativas, que parecen molestar mucho a las empresas en su actividad cotidiana. Algo muy diferente a lo que ocurre en nuestro país, en el que la potestad de inspección e investigación administrativa tiene un calado importante, hasta el punto en que suele ser la fase previa de muchos procedimientos sancionadores. En España esa potestad permite acceder a cualquier lugar de la empresa (y a su documentación) no protegido por el concepto de domicilio, recoger muestras y documentos, requerir información, etc. Además las actas conformadas durante y tras la realización de una inspección hacen prueba en contrario.

40 El Informe Macrory parte de la base de la existencia de 60 Agencias estatales y 4 g8 locales, todas las cuales deben adaptar su sistema sancionador a las sanciones previstas en el mismo, que después fueron recogidas por la RESA. 
chas de esas Agencias confían demasiado en las sanciones penales, que castigan conductas ilegales pero que nada aportan a la hora de evitar nuevos incumplimientos de la normativa. Las recomendaciones principales del Informe Macrory fueron las siguientes:

- Se aconsejaba al Gobierno que avanzara en la recomendación octava del Informe Hampton, que centraba su atención en rediseñar las sanciones administrativas para evitar que las empresas ya sancionadas volvieran a infringir la ley (re-offending), lo que exigía un tipo de sanciones flexibles graduables, algunas de las cuales podrían aplicarse en los estadios previos e inmediatamente posteriores a la comisión de una infracción.

- Se aconsejaba al Gobierno que apoderara a las Agencias con la potestad de imponer sanciones económicas variables, dentro de una horquilla prefijada, en caso de infracción de la normativa (regulatory breach);

- Se aconsejaba al Gobierno que mejorara y extendiera a todas las Agencias la potestad de emitir notices y enforceable undertakings: los primeros, a modo de avisos u órdenes administrativas para que una empresa infractora vuelva a cumplir la normativa, o para hacer que cese en su actuación infractora ${ }^{41}$; los segundos, como alternativa a la imposición de sanciones penales, a modo de acuerdos voluntarios entre la empresa incumplidora y la Agencia para llevar a cabo actuaciones concretas de restauración, indemnización y de evitación de nuevas infracciones.

- Se hace un Ilamamiento a las Agencias para que desarrollen en su propio ámbito normativo las sanciones básicas recogidas en la futura ley que las hubiese de regular (la RESA), instándolas a cambiar su punto de vista sobre la potestad sancionadora, otorgándole más transparencia y responsabilidad ${ }^{42}$.

41 Al estilo de lo que, desde 1946, exige la Administrative Procedure Act de los EE.UU., actualmente refundida en el US Code, cuyo art. 558, Subcapítulo II, Capítulo 5. ${ }^{\circ}$, de la Parte $1 .{ }^{a}$ del Título $5 .^{\circ}$, recoge los principios y los trámites procedimiental para imponer sanciones administrativas. La obligación de emitir una notice a la empresa licenciataria antes de revocarle, suspenderle, retirarle o anularle la licencia es un requisito esencial, así como el trámite de prueba ("opportunity to demonstrate or achieve compliance with all lawful requirements?]), el de audiencia previa y el de plazo de resolución razonable (?with due regard for the rights and privileges of all the interested parties or adversely affected persons and within a reasonable time").

42 En la legislación sectorial que aplica cada Agencia se incluyen sanciones de todo tipo, la mayoría de ellas no previstas en la RESA, como por ejemplo la revocación y/o suspensión de licencias; las cartas de advertencia (warning letters), la persuasión, etc. Como se ha dicho ya, el sistema sancionador británico hasta la RESA se basaba en el castigo por la vía penal de las infracciones a cualquier precepto de la ley, y por la carencia de tipos infractores concretos.

El Informe Macrory abogaba por aumentar el uso de sanciones administrativas para las infracciones leves y moderadas, a la vista de la rigidez del sistema penal y de su imposibilidad de atajar el incesante aumento de infracciones de las leyes que se viene dando en el Reino Unido en los últimos años, sobre todo de la normativa ambiental, de seguridad y de salud laboral. La creación de un nuevo régimen de sanciones administrativas en la RESA, como se verá más adelante, no deroga las sanciones imponibles conforme a la nueva regulación básica, pero sí las mejora, ya que las Agencias, antes de la entrada en vigor de la RESA, se 
- Finalmente, considera necesario que se mantenga la justicia penal, importante para atajar las infracciones más graves (los delitos, diríamos nosotros), en las que debe existir prevalentemente una importante base de voluntad infractora (dolo); y que los Tribunales de lo penal amplíen el tipo de sentencias y de medidas a imponer a los delincuentes, reduciendo la imposición de sanciones penales de tipo económico a aquellos delitos en los que el delincuente hubiera obtenido un importante provecho económico con la comisión del delito, en los que, por otra parte, el Informe propone aumentar el límite de sanciones penales imposibles; se proponen también otras soluciones más imaginativas que reemplacen a las sentencias con sanciones económicas, que eviten una hipotética reincidencia.

\section{Significado de las expresiones regulatory function y enforcement}

El art. 74 de la RESA remite al significado que, de la expresión regulatory function, da la Legislative and Regulatory Reform Act 2006 (LRRA), que, en su art. 32.2, la define como:

a) Función atribuida por cualquier ley, de imponer requisitos, restricciones o condiciones, o de establecer estándares o de dar instrucciones, en relación con una actividad dada, o

b) una función dirigida a asegurar el cumplimiento o la ejecución forzosa de esos requisitos, restricciones, condiciones, estándares o instrucciones, atribuida por una ley, en relación con cualquier actividad.

Como se ve, es algo más que una función normativa (como su traducción literal pudiera hacer creer), ya que, por un lado, incluye también guías o instrucciones, algo que en nuestro Derecho Administrativo no constituye propiamente normativa ni reglamento, sino, más bien, una interpretación oficial de los mismos, y, por otro, porque también engloba las funciones administrativas encargadas de hacer valer esa “normativa”, tales como la potestad sancionadora o la ejecución forzosa, por lo que, a la postre, regulatory function bien podría hacerse equivaler en nuestro Derecho administrativo como la suma de la actividad normativa de la Administración Pública y el ejercicio, por parte de ésta, de sus potestades de policía administrativa. Se trata, por tanto, de aquélla parte de la administración pública (en minúsculas) cuyo ejercicio haya de suponer un daño legítimo, no antijurídico, para el administrado, incluyendo también la regulación que la Administración realice de sus actividades.

La expresión enforcement es equiparable a nuestro concepto del privilegio de ejecutoriedad: la capacidad de la Administración del Reino Unido de hacer cumplir 108 quejaban de que a veces no disponían de las medidas de enforcement necesarias para perseguir y sancio- 
forzosamente frente a los Administrados su regulatory function, esto es, su actividad normativa y las potestades administrativas de gravamen que de ella se pudieran derivar.

\section{Aplicación territorial de la RESA}

La RESA se aplica, según qué partes, a todo el Reino Unido, lo que engloba a Inglaterra, Gales, Escocia e Irlanda del Norte. En Inglaterra se aplica por completo. En Gales se aplica tanto a las competencias propias de esta Nación (reserved matters, podríamos decir), como a las competencias transferidas (devolved matters).

En Escocia la Parte Primera de la RESA, en relación con la Local Better Regulation Office, no se aplica. Las Partes Segunda a Cuarta sólo se aplican a las competencias propias. Lo mismo ocurre en Irlanda del Norte.

\section{Estructura de la RESA}

La RESA se divide en cinco partes bien diferenciadas:

1. La Parte Primera (The Local Better Regulation Office), crea y regula la Local Better Regulation Office (LBRO en adelante), una nueva corporación gubernamental de base privada (government owned company), que desarrollará funciones de asesoría a la Administración local británica, y que tiene por misión, paladinamente, reducir la intervención administrativa sobre el sector empresarial.

2. La Parte Segunda (Co-ordination of Regulatory Enforcement), establece mecanismos de coordinación para que las Administraciones Locales puedan llevar a cabo de una manera más coherente y consistente su labor de hacer cumplir la regulación.

3. La Parte Tercera (Civil Sanctions), que es la que más nos importa en esta investigación, introduce un nuevo marco legislativo para las sanciones administrativas, denominadas en inglés, paradójicamente, civil sanctions, a aplicar por los reguladores (regulators), es decir, las Agencias y las Administraciones territoriales, permitiendo a los Ministros del Gobierno (Ministers of the $\left(r o w n^{43}\right.$ ) atribuirles potestad sancionadora en relación con infracciones concretas de la normativa. Nada se dice de las infracciones, pues cada ley sectorial crea las suyas propias, con sus propios regímenes de agravantes y atenuantes.

43 Son todos los ministros con cartera en el Gobierno de su Majestad la Reina Isabel II, incluyendo el Ministro del Tesoro, de Comercio y de Defensa (art. 8 de la Ministers of the Crown Act de 1975). En el Reino Unido los Gobiernos no son del Estado sino de la Corona. Es una expresión muy reveladora de la génesis de democracia inglesa a lo largo de los siglos, conformada sobre la base de concesiones de la Corona al Pueblo, esto es, a la Cámara de los Comunes. 
4. La Parte Cuarta (Regulatory Burdens), se dirige también a los regulators o reguladores, instruyéndoles sobre cómo evitar imponer gravámenes administrativos innecesarios a las empresas y agentes económicos. La finalidad de esta Parte de la Ley es semejante a la de la Parte Primera, reducir la carga administrativa que soportan los agentes económicos privados, imponiéndola sólo cuando sea necesaria.

5. La Parte Quinta (General), recoge elementos adjetivos comunes a las cuatro partes anteriores, de carácter interpretativo y normativo.

La RESA cuenta además con 7 Anexos (Schedules), sobre las siguientes materias:

- Anexo 1. : Disposiciones suplementarias sobre la LBRO;

- Anexo 2.: Sustitución de la LBRO Company por la LBRO: la LBRO Company era un organismo público constituido como empresa privada limitada, cuyas funciones, plantilla y propiedades se han transferido a la LBRO.

- Anexo $3 .^{\circ}$ : Leyes a las que se aplica la Parte Primera de la RESA;

- Anexo $4 .^{\circ}$ : La actuación de hacer cumplir y ejecutar las normas (enforcement) por la LBRO.

- Anexo 5. : Reguladores designados por la RESA;

- Anexo 6.: Leyes en las que se contienen infracciones a las que se pueden aplicar las Órdenes Ministeriales de atribución de la potestad sancionadora de la Parte Tercera;

- Anexo $7 .^{\circ}$ : Leyes a las que se aplica el art. 62 RESA.

\section{EL INDIRIZZO POLÍTICO DEL GOBIERNO DEL REINO UNIDO SOBRE EL EJERCICIO DE POTESTADES ADMINISTRATIVAS DE GRAVAMEN POR PARTE DE LAS ADMINISTRACIONES LOCALES: LA PARTE PRIMERA DE LA RESA (THE LOCAL BETTER REGULATION OFFICE, LBRO)}

En esta Parte, la RESA crea y regula la Local Better Regulation Office, corporación pública cuyo objetivo principal es asegurar que la Administración local (con el alcance que a la misma se le da en el art. 3 de la RESA) aplica la regulación nacional y ejerce sus potestades principales en relación con ella de manera efectiva, evitando imponer gravámenes administrativos innecesarios, conforme a los principios de buena regulación aprobados por la Better Regulation Commission ${ }^{44}$. Se ha comprobado que la aplicación

44 Esos principios, en referencia al ejercicio de las potestades administrativas de policía (regula110 tory functions), son: transparencia, responsabilidad, proporcionalidad, coherencia (consistency) y necesa- 
por las autoridades locales de la legislación nacional británica en materia de medio ambiente y comercio supone un $80 \%$ de todas las inspecciones a empresas llevadas a cabo en el Reino Unido. De ahí la importancia de proponer una mejora de las labores de control y ejecución normativa por parte de la RESA sobre las Administraciones locales ${ }^{45}$.

La LBRO trabaja con las Administraciones locales cuando ejerzan, en Inglaterra o Gales, "funciones relevantes" (relevant functions), esto es, cuando apliquen la normativa ambiental, de salud, comercio, autorizaciones administrativas, servicios de bomberos, y demás materias del art. 4.3 RESA ${ }^{46}$.

Pero el asesoramiento de la LBRO puede convertirse en una forma de indirizzo político, ya que incluso puede llegar a ejecutarse obligatoriamente cuando la LBRO lo crea conveniente, siempre que lo refrende el Secretario de Estado (art. 7 RESA), pudiendo llegar al extremo incluso de enumerar una lista de las partidas de gasto que deberían atender obligatoriamente, de manera prioritaria, los entes locales en Inglaterra, con el refrendo también del Secretario de Estado (art. 11 RESA). Si además tenemos en cuenta que el Secretario de Estado puede emitir guidance and directions para dirigir la actividad jurídica de la LBRO, se echa de ver claramente el alto grado de politización de este ente. Estas funciones sobrepasan con mucho las que realizan los organismos homólogos en España a nivel estatal (la Comisión Nacional de Administración Local, v. gr.,) o autonómico, cuyas funciones se centran más en labores de cooperación que de coordinación, por lo que serían vistas en nuestro país como un atentado a la autonomía financiera y política de la Administración local ${ }^{47}$.

Las funciones de coordinación de la LBRO se llevarán a cabo conforme al Regulators's Compliance Code y al Legislative and Regulatory Reform Order 2007 (LRR Order) ${ }^{48}$.

45 BERR (2008), DEPARTMENT FOR BUSINESS ENTERPRISE AND REGULATORY REFORM, Regulatory Sanctions Act 2008, Guidance to the Act, julio 2008, p. 9.

46 Vid. art. 4 RESA: se trata de funciones (potestades, podemos decir acomodando la expresión a nuestro Derecho Administrativo) atribuidas por leyes relevantes y que permiten llevar a cabo una actividad de policía administrativa para con empresas y negocios, imponiendo requisitos o condiciones a su actividad, o estableciendo estándares o dando instrucciones en relación con esa actividad; o de funciones (potestades) dirigidas a asegurar el cumplimiento de dichas empresas con esos requisitos, restricciones, condiciones, estándars e instrucciones. Se trata pues del establecimiento de licencias, requisitos, autorizaciones, etc., y de su ejecución frente a sus obligados (art. 4 RESA). La LBRO, en su Guía sobre Administraciones principales establece un elenco de categorías de funciones relevantes, que reproducimos aquí: age-restricted sales, agriculture, animal establishments and companion animal welfare, consumer credit, environmental protection, explosives licensing, fair trading, farm animal health, food safety and hygiene, food standards, general licensing, health and safety, housing, metrology, petroleum licensing, pollution control, product safety y road traffic. Cfr. LBRO (2009), Primary Authority Guidance, págs 6 y 28-30.

47 La lista de prioridades nacionales para las partidas de gasto locales fueron establecidas por el Informe Rogers en 2007 y son las seis siguientes: calidad del aire, control del consumo de alcohol, higiene alimentaria, incrementar la salud en el trabajo, comercio justo y salud animal. Cada tres años serán modificadas, en caso de que se estime pertinente.

48 Así como la aprobación de la RESA ha supuesto un incremento de las potestades administrativas de coerción, policía y gravamen, la verdad es que la filosofía que yace en su fondo es desregulatoria y liberalizante, ya que se dice sin ambages que la LBRO debe actuar de una manera amistosa con las empresas, de forma que el ejercicio de las potestades de policía por parte de las Administraciones locales no las 
También funciona la LBRO como una Administración staff o asesora, pudiendo emitir informes, cuando así se lo pida un Ministro, por ejemplo, sobre cómo deberían ejercer sus funciones relevantes alguna/s Administraciones locales, o con carácter previo o posterior a la aprobación de la legislación estatal, o sobre la posibilidad y adecuación de transferir potestades administrativas a las Administraciones locales inglesas y galesas, o sobre cualquier otra materia relacionada con el ejercicio, por las Administraciones locales, de sus funciones relevantes (art. 9 RESA). Como se ve, la LBRO tiene una función de asesoría doble (a la Administración local y al propio Gobierno), que otorga coherencia y da unidad a toda la política estatal sobre régimen administrativo local.

También puede la LBRO celebrar una especie de convenios de colaboración ( $m e$ morandum of understanding) con determinadas Agencias estatales, tales como la Environment Agency, la Food Standards Agency, la Gambling Commission, la Office of fair Trading y la Health and Safety Executive sobre cómo ejercer juntas sus competencias (art. 13 RESA).

Al igual que hace la Parte Cuarta de la RESA con determinadas Agencias, la LBRO no debe imponer gravámenes administrativos innecesarios, y puede, en su actividad,

molesten en su actividad empresarial ni les impida ser competitivas: “The Regulators' Compliance Code asks regulators to perform their duties in a business-friendly way, by planning regulation and inspections in a way that causes least disruption to the economy.". Este Código fue aprobado como consecuencia de la previsión incluida en el art. 22 de la Legislative and Regulatory Reform Act de 2006, que permitía, mediante Orden Ministerial, aprobar un Código de prácticas en relación con al ejercicio de las potestades administrativas (regulatory functions). Cfr. BERR (2007), DEPARTMENT FOR BUSINESS ENTERPRISE AND REGULATORY REFORM, Regulators'Compliance Code (Statutory Code of Practice for Regulators), 17 de diciembre de 2007. Este Código, que entró en vigor el 6 de abril de 2008, como consecuencia de la aprobación de la $L e$ gislative and Regulatory Reform Code of Practice (Appointed Day) Order de 2007, tiene como objetivo suavizar las labores de inspección, de aplicación y de ejecución de los incumplimientos de las normas, de modo que no impida el crecimiento económico de las empresas, llevando a cabo esas potestades siempre conforme al principio gerencial de evaluación de proporcionalidad, o de coste-beneficios (risk assessment) que sus actuaciones pudieran tener para las mismas, y tendiendo a ejercerlas fundamentalmente con las empresas reincidentes, dando información y consejo a las mismas sobre cómo cumplir con las normas. Como vemos, se trata de un enfoque no impositivo de las potestades administrativas, más cercanas a la pactación y al consejo que a la ejecución forzosa de las mismas, dejando la potestad sancionadora como última opción, que enlaza perfectamente con la filosofía de la LRRA y de la RESA. En su aplicación, ninguna Agencia podrá llevar a cabo inspecciones a posibles empresas infractoras sin una razón, debidamente motivada; ni requerir a esas empresas para que les dé información si no era necesaria para la represión de una determinada infracción, o si esa información ya se había obtenido previamente; y sólo debería imponer sanciones y demás actividades de enforcement cuando se trate de empresas renuentes y reincidentes con el incumplimiento de la normativa. La aplicación por las Agencias de estos principios del Código debe poder demostrarse y ser real, permitiendo la consulta previa de las empresas reguladas y emitiendo informes periódicos.

La $L R R$ Order establece en su Parte Primera qué Agencias y qué potestades deben someterse a los principios del Compliance Code y a los 5 principios de la Legislative and Regulatory Reform Act de 2006, ya mencionados también en la RESA, a saber: ejercicio transparente, responsable, proporcionado y consistente de las potestades administrativas (regulatory functions), y uso sólo en aquéllos casos en que sea necesario. Se impone así una especie de liberalismo administrativo, que afecta fundamentalmente a la imposición 112 de cargas y gravámenes por vía reglamentaria, muy propio del pragmatismo económico y jurídico del mundo anglosajón, algo que veremos también en la Parte Cuarta de la RESA. 
adoptar cualquier medida que sirva al cumplimiento de sus funciones, $y$, en particular, celebrar acuerdos, adquirir o vender sus propiedades, pedir dinero prestado e invertir dinero (art. 14).

\section{LA COORDINACIÓN DE LAS ADMINISTRACIONES LOCALES PARA EL EJERCICIO DE POTESTADES ADMINISTRATIVAS DE GRAVAMEN: LA PARTE SEGUNDA DE LA RESA (CO-ORDINATION OF REGULATORY ENFORCEMENT)}

En esta Parte de la RESA, a la que habría que añadir también el Anexo 4. ․, se promueve el empleo de mecanismos de coordinación entre los entes locales a la hora de aplicar la normativa y ejercitar sus potestades administrativas sobre las empresas que presten sus servicios o actividad en dos o más términos municipales, y apodera a la LBRO para resolver, a modo de árbitro, los conflictos que pudieran surgir entre ellas ${ }^{49}$.

La principal novedad de la RESA en este punto es que la LBRO está encargada de nombrar (nominate) y registrar a una Administración principal o primaria (Primary Authority), que será el Ayuntamiento, condado, etc. que queda así apoderado para coordinar el ejercicio de potestades administrativas de todos aquellas Administraciones locales en que esas empresas estén situadas, pasando por encima, por tanto, del propio término municipal sobre el que dicha Administración principal tiene jurisdicción. Para ello, es necesario que previamente a ese nombramiento, dicha Administración y la empresa concreta hubieran celebrado un acuerdo escrito para ese nombramiento, y que dicha empresa hubiera solicitado a la LBRO que nombrara a esa Administración como principal (Primary Authority). Si no se hubiera llegado a un acuerdo previo, la empresa puede pedirle a la LBRO que designe ella misma a la Administración principal que considere adecuada. En todo caso, la Administración principal debe ser aquélla en cuyo término la empresa o la persona jurídica presta principalmente sus servicios o desarrolla su actividad ${ }^{50}$.

El fundamento de estos acuerdos o voluntary schemes es la confianza mutua, y su objetivo general es dar seguridad jurídica (certainty) y coherencia a la información que la Administración principal pueda dar a la empresa con la que colabora sobre los estándares normativos nacionales, a aplicar a lo largo de todo el Reino Unido. Y esa

49 La LBRO dispone de 28 días para resolver los conflictos y dictar su "laudo". El procedimiento arbitral de la LBRO (referral process) quedó regulado en la Orden ministerial 670/2009, de 5 de marzo, que entró en vigor el 6 de abril del mismo año, que desarrolla este aspecto de la RESA. El principal parámetro de control que realiza la LBRO es la congruencia entre la acción de enforcement que se quiere aplicar y los consejos que haya dado previamente la Primary Authority (Administración Principal) al respecto, aunque puede resolver también que un determinado consejo o asesoramiento dado (guidance) es incorrecto, dándole la razón a la enforcement authority. Estos laudos pueden ser controlados a su vez por los Tribunales.

50 Cuando un Municipio no quisiera ser nombrado Administración principal deberá explicar las razones que le amparan, como, por ejemplo, carecer de los recursos económicos suficientes (art. 26.4 RESA). 
seguridad jurídica se supone que animará a las empresas a invertir con tranquilidad y a crecer, de nuevo un objetivo pragmático, poro formalista, muy del estilo inglés, que se expresa abiertamente en el comentario que el Gobierno hace de esta técnica51.

La información contenida en el acuerdo debe ser tenida en cuenta por otras Administraciones locales a la hora de realizar acciones de enforcement (hacer cumplir las normas) sobre la empresa que celebró el acuerdo con una Primary Authority, como pueden ser someter a la empresa a inspección o ejercer sus potestades administrativas sobre la mismas (por ejemplo, una sanción administrativa). De ese modo, una Administración local cualquiera que quiera imponer una sanción, o someter a inspección o autorización la actividad de una empresa que previamente firmó el acuerdo de colaboración con una Administración principal (u otras medidas de enforcement ${ }^{52}$ ), está obligada a informarla de ello y a consultar a ésta previamente, cuando se trate de materias como los estándares comerciales, protección y salud medioambiental, autorizaciones o protección contra incendios. Se excepcionan en la Orden 665/2009 ya indicada aquellas enforcement actions en las que exista urgencia, para evitar un riesgo significativo de daños para la salud humana o al medio ambiente o para los intereses financieros de los consumidores, o cuando se pudiera producir un daño menor a los intereses públicos (to protect the public from minor harm); en aquellos casos en que esa consulta sea desproporcionada, y en otros de menor importancia recogidos en esa Orden (esta Orden desarrolla el art. 29 de la RESA).

En caso de que la medida de enforcement adoptada por una Administración local no fuera coherente con las instrucciones dadas en su día por la Administración principal, ésta podrá ejercer una especie de veto, y dirigirse a aquélla para que no lo haga (art. 28 RESA). La Administración local que se niegue a seguir las instrucciones dadas por la Administración principal se lo dará a conocer a la LBRO, que decidirá si se ejecuta la potestad administrativa en la forma como quería aquélla o como imponía ésta, o si se busca una forma alternativa entre ambas. Las instrucciones, informaciones o planes de inspección adoptadas por cada Administración principal quedarán registra-

51 Cfr. LBRO (2008), Confidence and Consistency: The basics and benefits of the Primary Authority scheme, p. 4. Se entiende que las inversiones se realizarán en los municipios con los que hayan celebrado los acuerdos, aunque el Gobierno espera un crecimiento general de la actividad económica, dada su aplicabilidad a todo el Reino Unido. Otras posibles ganancias para el interés general de esos acuerdos son:

- la reducción de las infracciones administrativas, ya que las empresas conocerán de primera mano las normas y sus estándares. Se intenta que la Administración se acostumbre a una intervención previa a la infracción, advertiendo y aconsejando, evitando su tradicional de intervención ex post facto.

- El aumento de la competencia entre empresas del mismo ramo, ya que con estos acuerdos se establece una interpretación única de las normas sobre estándares ambientales, licencias, salud, etc., evitando así el debilitamiento que para la competencia supone que, muchas veces, cada Condado o Municipio module la aplicación de los mismos.

52 A los efectos de esta Parte de la RESA, las sanctions son un tipo de enforcement, entendiendo por sanction la imposición de improvement notices, el inicio de un proceso judicial, administrativo (civil) o penal, contra la empresa o la imposición de una multa. No serán consideradas enforcement la petición de consejo, oral u escrito, ni las demás actividades de investigación que no constituyan propiamente inspec114 ción. Cfr. BERR (2008), Regulatory Enforcement and Sanctions Act. Consultation on the Primary Authority
Scheme, septiembre de 2008, pp. 16 y ss. 
das en la LBRO, que también lleva el registro de cada Administración principal nombrada, y, por último, también ejerce una función como árbitro cuando surjan discrepancias entre varias Administraciones principales o entre ellas y otras Administraciones locales a la hora de hacer cumplir las normas.

La RESA llega al extremo incluso de permitir que la Administración principal y su empresa puedan pactar un plan de inspección en el que se recomiende a las otras Administraciones locales que quieran inspeccionar a dicha empresa cómo deben hacerlo, debiendo el Municipio que pretenda realizar una inspección a la empresa informar a la Administración principal de que no va a seguir las instrucciones dadas, motivándolo (art. 30). Esas instrucciones no pueden ser vinculantes porque vulnerarían la autonomía local del Municipio que pretende realizar la inspección 53 .

La clave del éxito de un acuerdo entre una Administración principal y una empresa radica, entre otras cosas, en el justo equilibrio que debe existir entre la relación cuasicontractual entre ambas y las actividades de enforcement que puedan llevar a cabo sobre la empresa otras Administraciones. Si la definición de actividad de enforcement fuera demasiado amplia, entonces la Administración principal se vería desbordada por la cantidad de trámites que tendría que resolver en relación con las Administraciones que quieren realizar dicha actividad. Por el contrario, si la definición fuera muy estricta, entonces el voluntary scheme firmado entre empresa y Administración principal no tendría sentido, pues en pocas ocasiones las demás Administraciones que vayan a someter a la empresa a una actividad de enforcement deberían de informar a la Administración principal de sus intenciones ${ }^{54}$.

53 Aunque la RESA no lo dice, el propio Gobierno, en su interpretación de la propia norma, considera que se podrían dar casos en que la LBRO pudiera revocar el nombramiento de una Administración principal, como por ejemplo que la empresa cambiara de sede o que fuese comprada por otro empresario (lo que determinaría que su actividad principal fuese prestada en otra parte del Reino Unido), o incluso en aquellos casos en que la Administración y la empresa hayan perdido la confianza mutua que originalmente les llevó a emparejarse. En esos casos la LBRO debe revocar el nombramiento y proceder a nombrar a otra Primary Authority, si es que ése es el deseo de la empresa o persona jurídica.

54 El Ministerio de Negocios, Empresa y Reforma normativa ha publicado recientemente un paper con el que pretende informar a las empresas, Administraciones principales y demás Administraciones que tengan que someter a la empresa a actividades de enforcement de las líneas principales para que cada una de ellas desempeñe adecuadamente su rol de acuerdo con el espíritu de la RESA. Así, por ejemplo, se delimita lo que sea enforcement de una manera equilibrada, excluyendo del concepto, por ejemplo, el consejo oral que pueda dar una Administración a la empresa. Por el contrario, si el consejo es escrito, se considerará enforcement si se trata de cartas enviadas por una Administración local a una empresa como advertencia de imposición de una multa o de cualquier otra sanción. Se excluye también del concepto el ejercicio por una Administración de su potestad de investigación sobre la empresa. El ejercicio de potestades de gravamen de competencia propiamente municipal también se excluye del ámbito objetivo de la Parte Segunda de la RESA, por lo que, contrario sensu, se incluye cuando esas potestades ejercitadas por Administraciones locales se refieren a materias de competencia estatal o nacional; no obstante, como excepción, un par de materias reguladas por dos normas estatales se excluyen estratégicamente también del ámbito de la ley: el otorgamiento de licencias conforme a la Licensing Act 2003 y la seguridad contra el fuego de la Fire Safety Order 2005. Sí entra en la definición, sin embargo, por presiones de las empresas durante la fase de consultas sobre este tema, toda la actividad de enforcement de la Parte $8 .^{\text {a }}$ de la Enterprise Act 2002, referente a la normativa a cumplir por las empresas en materia de consumidores y usuarios. Téngase en cuenta que la postura de las 
La Administración principal será responsable de dicha empresa o persona jurídica, pero no en un sentido de responsabilidad patrimonial (accountability) sino de responsabilidad jurídica formal y material (responsability) en relación con un/unos determinado/s sector/es de la actuación administrativa, que previamente quedaron acotados en el acuerdo, como por ejemplo medio ambiente, y/o seguridad, y/o salud, y/o comercio, etc., y a la que aplicará su regulación y potestades administrativas, cualquiera que sea el territorio o término municipal en el que esté desarrollando su actividad. En esos sectores la Administración principal se encarga de regular su actividad, de dar consejos e instrucciones a las empresas con las que acordó previamente su colaboración, en relación con la manera de cumplir las normas y el ejercicio de las potestades administrativas de ellas derivadas.

Lo que persigue la RESA en esta Segunda Parte es armonizar la regulación administrativa local en determinadas materias (art. 4.3) por encima de la propia autonomía municipal, ya que, en estos casos, un Municipio que no sea Administración principal y en cuyo término preste un servicio una empresa no podrá aplicarle su propia normativa, sino la de la Administración principal. Nos recuerda también la política reciente de la UE con su Directiva Bolkestein (Directiva 123/2006/CE, de 12 de diciembre), relativa a los servicios en el mercado interno ${ }^{55}$.

De las empresas que convinieron con una Administración principal se espera que cumplan mejor con la normativa nacional y con la aplicación que de la misma hace dicha Administración y otras Administraciones locales en las que puedan desempeñar sus actividades ${ }^{56}$.

empresas es que la definición de enforcement dé cabida al mayor número de actuaciones de la Administración local, porque así estarán obligadas en casi toda su actividad a informar a la Administración principal y, por tanto, deberán someterse a los términos del voluntary scheme firmado con ésta. También entra dentro del concepto de enforcement los enforcement undertakings celebrados entre una empresa y una Administración

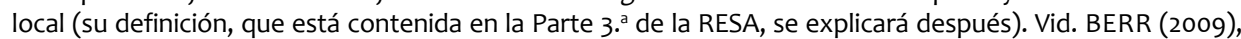
DEPARTMENT FOR BUSINESS ENTERPRISE AND REGULATORY REFORM, Government response to the consultation on the statutory instruments under the regulatory enforcement and sanctions act 2008, marzo 2009.

55 Recordemos que el mandato principal de esta Directiva es permitir la libre prestación de servicios en cualquier parte de la UE una vez que la empresa se hubiera establecido en cualquier otro Estado de la UE, que aplicará sus propios requisitos de apertura y funcionamiento y obligando, pues, a los Estados miembros a verificar y simplificar los procedimientos y trámites aplicables al acceso a una actividad de servicios y a su ejercicio. Con medidas parecidas, la RESA intenta hacer competir a los distintos municipios británicos entre sí (al igual que esa Directiva hace con los Estados de la UE), ya que una empresa elegirá como sede aquel Municipio (o Estado de la UE, siguiendo con ese paralelismo) en el que menos cargas y gravámenes administrativos se le impongan para su apertura. De nuevo late en el fondo de la RESA un liberalismo jurídico y desregularizador evidente, cuyos profundos efectos empezamos a columbrar, y que debe exigir un control jurisdiccional muy severo a posteriori para fiscalizar la validez de los estándares ambientales, económicos, de seguridad pública y demás, que puedan verse afectados con una normativa desregulatoria como ésta, y que, en aras de la competitividad empresarial y de la lucha de las Administraciones locales británicas (y Estados de la UE, conforme a esa Directiva) por los impuestos asociados al establecimiento de empresas, puede acabar erosionando los intereses públicos relacionados con el control de las actividades económicas.

56 Uno de los sectores que antes firmó acuerdos con sus respectivas Administraciones princi116 pales ha sido el de la alimentación. En 2008, seis de las grandes cadenas de distribución alimentaria 
La financiación de las actividades de las Administraciones principales se deja en manos de las mismas, aunque será un factor determinante a tener en cuenta por la LBRO a la hora de nombrar a una determinada Administración local como principal. En su art. 31 permite que las Administraciones principales puedan imponer tasas a las empresas conveniadas por el coste que le puede suponer la realización de sus funciones administrativas, lo que, sin duda, supone un estímulo para que las Administraciones locales británicas quieran ser nombradas Administraciones principales, más allá de los impuestos que les cobren en concepto de establecimiento, incluso de las ayudas que la LBRO puede otorgarles (art. 32.2 RESA).

En relación con los acuerdos o pactos celebrados entre la Administración principal y las empresas nos surge un importante escrúpulo de fondo, y es que en nuestro Derecho español, como sabemos, no se puede pactar el ejercicio de las potestades administrativas, ya que no es una materia susceptible de transacción, como recoge el art. 88 LRJAPyPAC y ha dicho tradicionalmente nuestro TS en relación con los convenios de colaboración de todo tipo (convenios urbanísticos o ambientales, v. gr.) por lo que no es improbable que muchos de los que valide o pueda validar la LBRO en nuestro país pudieran ser declarados nulos de pleno Derecho. Vemos una vez más cómo el pragmatismo del Derecho anglosajón está por encima de nuestras formas y garantías, algo que choca con nuestra mentalidad de juristas continentales, acostumbrada a las formas, a los dogmas, a la innegociabilidad de las potestades administrativas y a la preferencia de los instrumentos administrativos impuestos sobre los concertados, con todos los matices que ya hicimos en su día57.

Consideramos también que la Administración principal deberá ser especialmente cuidadosa con la información que da y con el contenido de lo que pacta con una empresa, ya que, inevitablemente, desde el punto de vista del Derecho español, se nos plantearían muchos problemas de responsabilidad patrimonial si como consecuencia de ello a la empresa la acabaran sancionando o inspeccionando al margen de lo acordado, en caso de que el pacto no recogiera adecuadamente la normativa nacional a aplicar. La protección de la confianza legítima de la empresa en lo pactado e informado por la Administración principal exigiría una indemnización por su parte a la empresa, al menos desde la óptica de nuestro Derecho Administrativo ${ }^{58}$.

del Reino Unido celebraron acuerdos piloto (B\&Q, Boots, John Lewis, Tesco, Sainsbury's yWaitrose), con resultados muy satisfactorios, en opinión del Gobierno británico. Algunas cadenas optaron por celebrar un único acuerdo con una Administración local, que incluía bajo su cobertura a todas las sedes de la compañía, desperdigadas por UK; otras optaron por celebrar un acuerdo-tipo por cada una de sus sedes, algo más complejo, pero posible. Lo que nunca se podrá hacer es celebrar más de un acuerdo empresa-Administración principal para cada una de las categorías de funciones relevantes (relevant functions).

57 Cfr. In toto, Sánchez Sáez, A. J. (2004), Los convenios de colaboración para la protección del medio ambiente, opus cit.

58 En marzo de 2009 se ha aprobado la Primary Autothority Guidance, por parte de la Local Better Regulation Office (LBRO), en la que se desarrollan y explican las formas de actuación previstas en la RESA para las Administraciones principales (Primary Authorities). 
Para garantizar la cohesión de la actividad de las Administraciones principales y de las Administraciones locales que ejerzan sus potestades administrativas sobre las empresas, la LBRO podrá emitir instrucciones destinadas a determinadas Administraciones locales sobre el modo de cumplir sus funciones, que son de cumplimiento obligatorio, siempre que hubiesen sido ratificadas por el Secretario de Estado y que las publique previamente (art. 33 RESA).

\section{EL RÉGIMEN JURÍDICO DE LA POTESTAD SANCIONADORA RECOGIDO EN LA PARTE TERCERA DE LA RESA (CIVIL SANCTIONS)}

\section{La mixtificación de las infracciones y sanciones penales y administrativas en el Reino Unido}

Resumidas ya las dos primeras partes de la RESA, en la que se enmarcan las líneas maestras del ejercicio de potestades de gravamen, $y$, por tanto, de la potestad sancionadora, ejercidas por las Administraciones locales, nos centraremos ahora de aquí al final de este estudio en esta parte de la Ley, la más importante, en la que se recoge el nuevo régimen jurídico de las sanciones administrativas a imponer por las Agencias y demás Administraciones nacionales (Escocia, Inglaterra, Gales, Irlanda del Norte) y locales del Reino Unido en general a las empresas, negocios y agentes económicos infractores de la normativa estatal, como alternativa al que hasta ahora había sido el régimen sancionador vigente en el Reino Unido, basado en la persecución penal de las infracciones a las normas ${ }^{59}$.

En este sentido resulta esencial resaltar una de las principales diferencias del Derecho penal británico y español, y es que en el Reino Unido no hay problema jurídico en reconocer la responsabilidad penal de una empresa, al contrario de lo que ocurre en nuestro país, en el que rige el aforismo societas delinquere non potest, aunque

59 La tendencia a la sustitución de los delitos por sanciones administrativas no nace en la RESA, sino que era una necesidad sentida en muchos sectores regulados. Así, por ejemplo, el sector de la aviación civil, preguntado por el Gobierno, consideraba que era más correcto sancionar administrativamente a las compañías aéreas por infracciones de la Ley de aviación civil muy comunes, en las que no existía mala fe o dolo, como en la práctica de overbooking, cobros indebidos por transportar equipajes pesados, excesivo celo en los controles, denegación de embarque, etc. Vid. Explanatory memorandum to the Civil Aviation (access to air travel for disabled persons and persons with reduced mobility) Regulations 1895/2007, punto 7.9 .

También el sector de la acuicultura se ha mostrado a favor de reemplazar el sistema de faltas y delitos por el de sanciones administrativas, en particular, por el de multas económicas [financial administrative penalties (FAPS)], demostrando incluso que este tipo de sanciones tiene un efecto disuasorio (deterrence) mayor que las penas impuestas por la comisión de delitos, y que reducen el tiempo y coste de defensa de las empresas infractoras. Vid. Executive note: The aquaculture and fisheries (Scotland) act 2007 (fixed penalty notices) Order 2008 - ssi 2008/101.

E igualmente se han creado sanciones administrativas derivadas de la normativa comunitaria, como es el caso de las infracciones y sanciones recogidas en el Reglamento galés sobre identificación y registro 118 de ganado. Vid. The Cattle Identification (Wales), Regulations 842/2007 (W 74), y en el Reglamento galés sobre cuotas lácteas. Vid. The Dairy Produce Quotas (Wales) (Amendment) Regulations 911/2004 (W94). 
sí sean imputables penalmente las personas físicas que toman las decisiones empresariales. Por el contrario, tanto en UK como en España las infracciones administrativas pueden ser cometidas por personas físicas o jurídicas, que serán convenientemente sancionadas.

Pero la diferencia de fondo radica en la inexistente delimitación formal que existía en el Reino Unido, hasta hace bien poco, entre las infracciones y sanciones penales (criminal infractions and sanctions) y las administrartivas (civil infractions and sanctions). La RESA ha venido a poner un poco de orden en esa distinción, pues si hasta ahora era muy común que infracciones leves o moderadas de las leyes fuesen perseguidas penalmente y castigadas como delitos, desde su aprobación las Administraciones cuentan con un "armamento" administrativo, mucho más flexible, para hacer frente a ese tipo de infracciones no muy graves. Con la RESA el Derecho británico ha venido a darle la razón al Derecho continental, que siempre ha visto en el ius puniendi penal del Estado una razón última y vicarial que deja un gran campo de actuación a la potestad sancionadora de carácter administrativo para las infracciones de menor enjundia, normalmente en atención a los intereses generales protegidos. A ello se suma el hecho de que tanto en el Reino Unido como en España las sanciones administrativas no pueden imponer penas privativas de libertad, lo que solapaba, hasta ahora, las sanciones penales de carácter económico con las multas administrativas (penalties, la forma más usual, hasta ahora, de sanciones administrativas), haciéndolas indistintas en sus consecuencias ${ }^{60}$.

Tradicionalmente, en el mundo anglosajón, las sanciones penales (criminal offences) atendían a un interés público, y eran perseguidas públicamente para infligir un castigo al responsable, mientras que las sanciones administrativas (penalties, civil sanctions) eran sanciones de carácter civil, en las que no existía un interés público tan importante, y cuya finalidad era simplemente compensar a la víctima del daño. Esta percepción ha cambiado en los últimos años, ya que la opinión pública y las propias Administraciones y tribunales han reparado en la existencia de intereses públicos en las sanciones civiles (o administrativas, en nuestra terminología). También la experiencia de otros países anglosajones ha influido ${ }^{61}$.

60 De todas formas, siempre hay una zona gris entre la potestad sancionadora penal y administrativa, tanto en España como en el Reino Unido. Como sabemos, en nuestro país se han dado casos en que algunos delitos se han convertido en infracciones administrativas y a la inversa (el sangrante caso de la venta ilegal de CDs o DVDs piratas), algo que está en íntima relación con la sensibilidad social en cada momento. De manera parecida, en el Derecho británico, como veremos, cuando una sanción administrativa no es pagada de manera renuente por el sujeto sancionado, la infracción puede convertirse en delito, y pasa a la vía penal. Aún así, la tendencia parece ser común también en ambos Derechos, y se inclina por reducir más si cabe la infracción penal en aras de la administrativa: el atasco judicial, los formalismos, la incapacidad de la vía penal para proteger los intereses generales o la ignorancia de las leyes administrativas por parte de los jueces abogan por esto último.

61 El caso de Australia es paradigmático, ya que en la Parte $4 .{ }^{\text {a }}$ de su Trade Practices Act de 1974 se incluyen sanciones administrativas (civil sanctions), para evitar criminalizar conductas leves o moderadas. Desde entonces cada ley sectorial administrativa australiana ha incluído su propio capítulo ad hoc con diferentes tipos de sanciones administrativas. Algo parecido viene haciendo en las últimas décadas 
En esta parte de la RESA los Ministros del Gobierno pueden otorgar o reconocer (confer) potestad sancionadora a determinadas Agencias (regulators ${ }^{62}$ ), potestad que es de titularidad estatal y cuya regulación podríamos denominar como básica del Estado, como nos recuerda la propia RESA, que impone a aquéllas condiciones y estándares mínimos para su ejercicio ${ }^{63} . \mathrm{Y}$, como toda la Ley está recorrida, como ya se ha dicho, por la finalidad de reducir la intervención administrativa al mínimo necesario, también el ejercicio de la potestad sancionadora y su atribución ministerial a las

Canadá, que viene sustituyendo sus sanciones penales por las administrativas, a raíz de las conclusiones emitidas por la Law Reform Commission of Canada, a mediados de los años 70. Cfr. AUSTRALIAN LAW REFORM COMMISSION, Securing Compliance: Civil and Administrative Penalties in Federal Regulation, 2000, pp. 57 y ss. y LAW REFORM COMMISSION OF CANADA (1976), Our Criminal Law, 4, Information Canada, Ottawa, p. 33.

62 Cfr. Art. 37 RESA, que engloba en su ámbito objetivo a las Agencias incluidas en el Anexo 5 y a todas aquellas personas que tengan enforcement function (Municipios, Ministros, etc.), si bien excluyendo de este último criterio a los agentes de policía, al Ministerio fiscal, y a los servicios de persecución de delitos (prosecution service).

Otra norma que ha incluido sanciones administrativas, incluso desde mucho antes que la RESA, es la Companies Act 1985, que establecía unos límites a las sanciones económicas (fines) a imponer a aquellas sociedades limitadas que se retrasaran en entregar sus cuentas, para ser revisadas y registradas públicamente. Pues bien, mediante una reforma legal de esa ley, que se hizo en 2006, se permitía que por desarrollo reglamentario se pudieran concretar las penas. El Reglamento 497/2007 ha aumentado las penas recogidas en 1985, doblándolas incluso en casos en que existiera más de un año de retraso. Vemos que el papel de los reglamentos ejecutivos en el Reino Unido, en relación con la potestad sancionadora, excede con mucho del que tienen en España. Como sabemos, el art. 25 CE establece un rígido principio de legalidad en la determinación de las infracciones y sanciones penales que, sin embargo, se suaviza un tanto en el Derecho administrativo sancionador: en España se admite con ciertas limitaciones las normas sancionadoras en blanco (leyes que sancionan infracciones de reglamentos u ordenanzas), y los reglamentos ejecutivos pueden actualizar las sanciones administrativas recogidas en leyes, e incluso desarrollar o concretar sanciones (con permiso previo de la ley), si bien no pueden incrementarlas más allá de lo que establezca la ley, ni ésta puede deslegalizar la determinación de las penas más allá de la horquilla prevista en la la misma (art. 129 LRJAPyPAC). Eso sí, en materia de régimen local, para consagrar una mayor autonomía local sancionadora, la Ley 57/2003, de 16 de diciembre, de Medidas para la modernización del gobierno local, que ha reformado la LRBRL, ha permitido que los municipios puedan tipificar infracciones en determinados ámbitos siempre que las sanciones que impongan no superen los 3.000 euros (arts. 139-141 LRBRL). Vid. The companies (late filing penalties) and limited liability partnerships (filing periods and late filing penalties), Regulations 497/2008.

También la Financial Services and Markets Act 2000 ha incluido sanciones administrativas a entidades aseguradoras y bancos, pero con la peculiariedad de que son impuestas por la High Court (véanse arts. 107 y 111).

63 La exigencia de una ley previa que permita a las Agencias imponer gravámenes es común a todo el Derecho anglosajón, inicialmente en Inglaterra, en cuya historia jurídica la lucha entre el Rey y el Parlamento determinó la necesidad de que éste le otorgara el placet a aquél para imponer gravámenes. Recordemos la Petitions of Right, de 1628, que establecía: «No person shall be deprived of life, liberty or property without due process of law.». También se puede ver lo propio en EE.UU., en el art. 558 del US Code, que se refiere a la imposición de sanciones, en el que se dice "A sanction may not be imposed or a substantive rule or order issued except within jurisdiction delegated to the agency and as authorized by law". Y también en la Constitución australiana, en su art. 53: "Proposed laws appropriating revenue or moneys, or imposing taxation, shall not originate in the Senate. But a proposed law shall not be taken to appropriate revenue or moneys, or to impose taxation, by reason only of its containing provisions for the imposition or appropriation of fines or other pecuniary penalties, or for the demand or payment or appropriation of fees for licences, or fees for services under the proposed law". Cuando caben distintas multas o sanciones para una misma infracción, el Derecho australiano exige que la imponga un Tribunal (Court), una vez hecho lo cual podrá la Agencia determinar la cantidad exacta o el grado exacto de sanción a aplicar, incluso recoger alguna cláusula de exoneración o reducción de la responsabilidad. 
Agencias y demás Administraciones queda condicionada expresamente en su art. 66 a dicha finalidad. Efectivamente, son los principios del art. 5 RESA la quilla de la nave, lo que puede incluso interpretarse como que el Gobierno británico no desea Agencias hiperactivas en materia sancionadora, celosas de las normas, sino Agencias que sólo sancionen a las empresas que cometan infracciones graves o que tengan un historial abultado como infractoras, mirando hacia otro lado o simplemente advirtiendo a aquellas otras empresas que vulneren puntualmente las leyes.

En España esta interpretación material, finalista y maleable de la potestad sancionadora, sazonada con otras condiciones que veremos más adelante, contravendría varios principios básicos del Derecho Administrativo (el principio de inderogabilidad singular de los reglamentos, el de irrenunciabilidad del ejercicio de las potestades administrativas, el de prohibición de la desviación de poder, aunque fuese con fines públicos, el de interdicción de la contractualización de potestades administrativas, etc.) y va más allá, también, del concepto de fomento jurídico. Parece que importa más al Legislador británico el mercado y sus posibles intereses generales que los intereses generales abstractos derivados de las potestades de policía, que se denominan en la RESA, un tanto peyorativamente, como cargas o gravámenes administrativos (administrative burdens ${ }^{64}$ ).

64 La definición de burden la podemos encontrar en la LRRA de 2006, en su art. 1. ${ }^{\circ}$, y es bastante amplia. Podríamos hacerla equivaler a la expresión “obstáculo" que encontramos en el art. 9.2 de nuestra Constitución, o "carga”, como ha sido traducida en el Plan español de reducción de cargas administrativas, si bien la expresión británica, como veremos ahora, se refiere más a obstáculos jurídicos, no a problemas preexistentes a las normas. En su art. 1.3, la LRRA define burden como un coste económicofinanciero, un inconveniente administrativo, un obstáculo para la eficiencia, productividad o rentabilidad, o una sanción, penal o administrativa, que pueda afectar a cualquier actividad regulada. Éste último apartado (el d), es el que ha sido desarrollado por la Parte Tercera de la RESA, ya que la potestad sancionadora es vista en el Reino Unido como una medida de enforcement, y todas las medidas de enforcement son susceptibles de ser consideradas burdens, cuando se apliquen de manera desproporcionada, rígida y generalizada.

Los costes económicos y los inconvenientes administrativos pueden referirse a cargas o requisitos innecesarios para ejercer un derecho (por ejemplo una licencia nueva que en realidad no se justifica porque no ampara ningún interés público) o incluso a las dificultades de entendimiento y comprensión de la normativa estatal o local que pueden significar a los agentes económicos pequeños y medianos cuando están mal redactados o expresados en las normas (art 1.5 LRRA). Otras veces la expresión burden se quiere hacer equivaler a burocracia, como ha hecho el Gobierno británico en un informe de 2007 sobre la reducción de la burocracia en los servicios públicos. En él se pretende reducir las inspecciones y visitas a los servicios públicos de una semana a dos días, reducir la cantidad de datos que se recoge de dichos servicios, aligerar el papeleo que tienen que sufrir pacientes en hospitales o padres y colegiales en la escuela, etc. Cfr. H.M. Government (2007), Cutting burocracy for our public services, junio 2007. El ideal gubernamental es que los servicios públicos se acerquen al nivel de rapidez y calidad de los servicios privados.

La Comunicación de la Comisión al Consejo, al Parlamento Europeo, al Comité Económico y Social Europeo y al Comité de las Regiones, de 24 de enero de 2007, «Programa de Acción para la Reducción de las Cargas Administrativas en la Unión Europea» [COM (2007) 23 final] define costes administrativos como los "costes habidos por las empresas, el sector asociativo, los poderes públicos y los ciudadanos para cumplir las obligaciones legales de facilitar información sobre sus actividades (o su producción), ya sea a las autoridades públicas, ya sea a entidades privadas" y "exceso de reglamentación" como la reglamentación excesiva se produce cuando una autoridad transpone un texto creando o ampliando las obligaciones previstas inicialmente. 


\section{2. Ámbito territorial de la Parte III de la RESA}

El ámbito territorial de aplicación de la Parte Tercera de la RESA incluye a todo el Reino Unido, si bien para Gales se aplica sólo a todas las competencias administrativas transferidas, mientras que no se aplica a las competencias transferidas a Escocia e Irlanda del Norte ${ }^{65}$.

\section{3. Ámbito subjetivo de la Parte III de la RESA}

Dentro de ese ámbito territorial, su ámbito subjetivo son, fundamentalmente, las Agencias de la Administración estatal y local.

La potestad sancionadora es conferida por Orden Ministerial, lo que resulta extraño a los ojos de un jurista español, habida cuenta de la importancia del principio de legalidad. Es la RESA la que permite esa atribución, cierto, pero, como nos recuerda Betancor, es el Poder ejecutivo, un Ministro, el que transfiere la potestad a una Agencia concreta, de entre las que recoge la RESA, desarrollando lo que dice la Ley para ese caso concreto, y delimitando el alcance de la potestad sancionadora atribuida en cada caso $^{66}$. La RESA permite esa transferencia, previa Orden ministerial, a determinadas Agencias (Regulators), de entre las siguientes:

- En primer lugar, las elegidas por la propia RESA, enunciadas en el Anexo 5 de la RESA: veintisiete Agencias nacionales, entre las cuales se encuentran las más importantes del Reino Unido por volumen de trabajo o presupuestario, tales como la Agencia de Medio Ambiente, la Comisión de Juego, la Autoridad del Carbón, la de Vivienda, Sanidad o Pesca...

- En segundo lugar, las Agencias encargadas de ejecutar las infracciones de las Leyes enumeradas en el Anexo 6 de la RESA, que, en sus tres páginas de letra apretada engloban las principales leyes de intervención administrativa del Reino Unido, como las de Energía, Empresas, Medio Ambiente, Administración Local, Autorizaciones, Seguridad y Salud en el trabajo, etc...

- En tercer lugar, las Agencias encargadas de hacer cumplir la legislación delegada (secondary legislation, también denominada subordinate legislation o delegated

65 Es decir, que dentro de esta Parte Tercera, un Ministro del Gobierno estatal británico no puede aprobar ninguna una Orden que pudiera afectar a las competencias legislativas del Parlamento escocés y de la Asamblea legislativa norirlandesa, siempre que esa competencias estuvieran desarrolladas mediante Ley. Al contrario, para que un Ministro de la Corona pudiese aprobar una orden que haya de surtir efecto en Gales, debe consultar a los Ministros galeses con carácter previo, y si esa orden, además, afecta a materias de competencias asumidas por el Gobierno galés, además necesitará el consentimiento previo de dichos Ministros. En sentido inverso, los Ministros galeses deben consultar al Secretario de Estado británico antes de aprobar sus propias órdenes para otorgar potestad sancionadora a sus propias Agencias nacionales o locales (arts. 56-59 RESA). 66 Cfr. Betancor, A (2009), “Derecho Administrativo sancionador...”, opus cit., p. 7. 
legislation) que desarrolla las Leyes incluidas en el Anexo 7 de la RESA, muchas de las cuales se encuentran también recogidas en el Anexo 6 antes visto. La legislación delegada es parecida a nuestros Reales Decretos Legislativos, esto es, es la aprobada por el Poder ejecutivo dentro de los poderes delegados por la legislación primaria (primary legislation, emanada del Parlamento), para ejecutar o desarrollar los requisitos recogidos en ella. Tiene rango de Ley, al igual que nuestros Reales Decretos-Legislativos. La razón de ser de este tercer tipo de Agencias es no dejar fuera un importante número de infracciones recogidas por el Gobierno en este tipo de normas delegadas.

Se puede observar que mientras que el primer grupo de Agencias pertenece a la Administración General del Reino Unido, las del segundo y tercer grupo pueden ser locales o nacionales, en aplicación y ejecución de leyes nacionales, con lo que el resultado final es casi exhaustivo y muy numeroso y engloba a casi la totalidad de Agencias nacionales y locales de UK, que puedan trabajar e imponer sanciones por sí mismas o bien colaborando unas con otras (normalmente Agencias Nacionales con Agencias Locales).

Para atribuir la potestad sancionadora a una Agencia el Ministro debe posteriormente, una vez acabado el procedimiento de auditoría de la misma, contar con el consentimiento del Panel for Regulatory Accountability (PRA) ${ }^{67}$, órgano gubernamental que vigila la proporcionalidad y necesidad del impacto de los gravámenes administrativos impuestos por la Administración (administrative burdens) a las empresas y negocios. Finalmente se abre un trámite de información pública (public consultation), en el que el Ministerio escucha a la Agencia y a las organizaciones y personas que el Ministerio considere representativas de los intereses afectados por la propuesta (normalmente el sector empresarial), art. 60 RESA. Posteriormente, la Orden ministerial debe aprobarse por ambas Cámaras del Parlamento (art. 61), lo que le otorga un amplio respaldo popular a la decisión de la atribución de la potestad sancionadora a una Agencia, y que supera la atribución de potestades que, en España, la Administración General del Estado puede llevar a cabo para con sus organismos públicos ${ }^{68}$.

67 Es un Subcomité dentro del Comité Ministerial de Desarrollo Económico (Ministerial Committee on Economic Development), y presidido por el Primer Ministro.

68 La Ley 6/1997, de 14 de abril, de Organización y Funcionamiento de la Administración General del Estado (LOFAGE) exige que la Ley de creación del OA o de la EPE establecerá los fines generales, y establece que los Estatutos de los OAs y de las EPEs deberán determinar qué potestades ostentan para cumplir con esos fines (art. 62.1, b LOFAGE), y que podrán ser ampliadas mediante el procedimiento adecuado de modificación. Los Estatutos deberán ser aprobados por el Consejo de Ministros, a iniciativa del titular del Ministerio de adscripción y a propuesta conjunta de los Ministros de Administraciones Públicas y de Economía y Hacienda (art. 62.3 LOFAGE). Además, las modificaciones o refundiciones de Organismos autónomos o entidades públicas empresariales, cuando no suponga la alteración de sus fines generales, del tipo de Organismo público o de las peculiaridades relativas a los recursos económicos, al régimen de personal, de contratación, patrimonial, fiscal y cualesquiera otras que exijan norma con rango de Ley, se llevarán a cabo, aunque supongan modificación de la Ley de creación, por Real Decreto acordado en Consejo de Ministros, a propuesta conjunta de los Ministerios de Administraciones Públicas y de Economía y Hacienda, y a iniciativa del Ministro o Ministros de adscripción o, en todo caso, de acuerdo con el mismo 
Una vez entre en vigor la Orden ministerial, su aplicación por parte de la Agencia deberá ser revisada por el Ministro antes de que pasen tres años desde su entrada en vigor, para lo cual deberá consultar a las personas que considere adecuadas (por supuesto, la Agencia entre ellas) y publicar los resultados de esa revisión. También deberá dejar una copia del informe en el Parlamento (art. 67 RESA). Se trata de una revisión de la actividad de la Agencia muy parecida a la que en España lleva a cabo el Ministro sobre sus organismos autónomos (art. 51 LOFAGE).

La potestad sancionadora, por tanto, no se otorga ministerio legis de manera automática a todas esas Agencias: lo que hace la RESA es decir qué Agencias son elegibles para que se les pueda atribuir esa potestad, lo que se hace mediante Órdenes ministeriales. Pero antes de ello, el Ministro debe auditar a la Agencia para asegurarse de que va a seguir los 5 principios de buena regulación ya citados, ya las buenas prácticas recogidas en los Informes Macrory y Hampton, lo que se hace a través de un procedimiento de auditoría conocido como Hampton Implementation Reviews $(\mathrm{HIR})^{69}$.

Todo ese arsenal de instrumentos sancionadores administrativos supone una alternativa preferible a las rígidas y no siempre satisfactorias en términos de protección de los intereses públicos vulnerados medidas sancionadoras, tradicionalmente preferidas por los Tribunales, como son las criminal sanctions, aunque puntualmente en casos concretos de mucha gravedad aún podrían imponerse. Al contrario, cuando las infracciones fuesen de menor importancia, siempre le cabe a las Agencias adoptar otras medidas de enforcement más suaves, sin tener que llegar a imponer una sanción administrativa: cabe entonces echar mano de consejos o instrucciones o advertencias (advice, guidance, warning letters).

El Ministro puede suspender el ejercicio de la potestad sancionadora por una Agencia cuando haya tenido constancia de su mal uso continuado (por más de una vez, dice la $\operatorname{RESA}^{70}$ ), y haya fracasado en sus advertencias previas (art. 68). Para otros casos de mal uso o abuso puntual de dicha potestad podrá siempre la empresa san-

(art. 63.2 LOFAGE), método que puede emplearse para atribuir una nueva potestad no incluida inicialmente, a salvo la expropiatoria, que no es conferible bajo ninguna circunstancia (art. 42.2). En parecidos términos se expresa la Ley 28/2006, de 18 de julio, de Agencias estatales para la mejora de los servicios públicos para las Agencias.

69 A través del Hampton Implementation Reviews, el Ministro inspecciona si la Agencia cumple los principios de buena regulación del Informe Hampton (transparent, accountable, proportionate, consistent and targeted only at cases where action is needed) y en qué grado, y si las sanciones que pretenden imponer se ajustan a la Tercera Parte de la RESA, en el entendimiento de las mismas que preveía el Informe Macrory. Ese procedimiento, además, anima a la Agencia a adoptar buenas prácticas de gestión y de mejora continua. Se ha realizado en dos fases, de forma que en la primera de ellas fueron auditadas 5 grandes Agencias nacionales como la de Salud y Seguridad, Alimentaria, la de Servicios Financieros, la de Medio Ambiente y la de Comercio, mientras que en una segunda fase aún vigente se están auditando 31 Agencias más con un procedimiento HIR mejorado.

70 Dentro de ese mal uso se incluye el no atender al contenido de su propia guía para ejercer la 124 y de proporcionalidad del art. 5 RESA. 
cionada recurrir judicialmente la sanción ante un Tribunal independiente. Si la Agencia adoptara las medidas adecuadas para cumplir con la RESA, con sus obligaciones o con las Instrucciones que la misma hubiese aprobado previamente a la imposición de determinadas sanciones, el Ministro podrá revocar la suspensión. Antes de adoptar la medida de suspensión y la de revocación de la misma el Ministro debe escuchar en audiencia a las partes implicadas e incluso notificar al Parlamento su decisión. A nosotros los juristas españoles nos parece extraño que la potestad sancionadora pueda suspenderse, aunque con la LOFAGE en la mano no lo debería ser tanto, ya que la Administración matriz sí tiene ciertas facultades en relación con las potestades que descentralizó funcionalmente en sus organismos públicos, equiparables a ésta (recordemos que por Real Decreto puede la Administración modificar los Estatutos del organismo, recuperando la potestad sancionadora, por ejemplo, si la tenía atribuida, o cualquier otra, ex art. 63.2 LOFAGE, o el control de eficacia que ejerce el Ministro sobre las funciones ejercidas por el organismo, ex art. 51 LOFAGE).

\section{4. Ámbito objetivo de la Parte III de la RESA}

Algunas de las medidas que la RESA define como sanciones no lo serían propiamente en nuestro Derecho, pero es que la palabra "sanction" no es absolutamente equivalente a nuestro término jurídico-administrativo de "sanción”, sino que tiene un ámbito objetivo más amplio, como ocurre en todo el Derecho anglosajón. Recordemos, así, que en la norteamericana Administrative Procedure Act de 1946, se entiende por sanción la prohibición, exigencia, limitación o, en general, toda condición restrictiva de la libertad personal, la imposición de penalidades o multas, la destrucción o expropiación de la propiedad, la revocación o suspensión de una licencia. En palabras de Villar Palasí, "engloba por tanto el término español agravio, que resulta el único adecuado para la traducción del sentido legal de sanction. Lo contrario a ésta es el relief, que debe por ende traducirse por desagravio o privilegio, comprendiendo dentro de la ley: la concesión de subvenciones, asistencia, licencia, concesión de dominio público, exenciones, privilegios, aceptación y estimación de recursos procesales"71.

Tanto en el Derecho británico como en el Derecho estadounidense el concepto de sanción es más amplio que en el Derecho Administrativo español, fundamentalmente porque en España la sanción se restringe a la imposición de un mal o castigo autónomo a la persona infractora, ocasionada por la infracción de una norma, que tiene una finalidad meramente punitiva o disuasoria, y que, aunque puede acarrear la imposición de medidas accesorias para recuperar el bien dañado con la infracción o

71 Cfr. Villar Palasí, J. L. (1959), “La Federal Administrative Procedure Act de Estados Unidos”, RAP, n. ${ }^{\circ}$ 1, p. 279. Actualmente, este precepto se encuentra en el apdo. $10 .^{\circ}$ del art. 551 del US Code, que define sanción como "prohibition, requirement, limitation, or other condition affecting the freedom of a person; withholding of relief; imposition of penalty or fine; destruction, taking, seizure, or withholding of property; assessment of damages, reimbursement, restitution, compensation, costs, charges, or fees; requirement, revocation, or suspension of a license; or taking other compulsory or restrictive action". 
indemnizar a las personas lesionadas, no va dirigida principalmente a la satisfacción de los intereses generales. Así, en España, no son sanciones medidas como el derribo de una casa que incumple la normativa urbanística, o la devolución de subvenciones ganadas irregularmente o no justificadas, o la revisión o suspensión de licencias, la orden de cierre de establecimientos o de retirada de productos defectuosos del mercado, que sí pueden ser consideradas civil sanctions en las leyes sectoriales del Derecho británico (ver anexos de la RESA) ${ }^{72}$.

\section{El marco sancionador en el Reino Unido desde la aprobación de la RESA: distribución de competencias en materia sancionadora}

Desde octubre de 2008, por tanto, el Derecho sancionador británico ha quedado constituido por:

- una normativa general (la RESA), que puede considerarse, salvando las distancias, como una Ley básica en el sentido que a ese adjetivo damos en España, lo que determina un efecto vinculatorio general: es decir, que el procedimiento sancionador y las sanciones en ella recogidas son de obligatorio cumplimiento para todas las Administraciones territoriales del Reino Unido. No obstante, la RESA recoge un abanico de nuevas sanciones administrativas (civil sanctions) con un amplio ámbito subjetivo y objetivo, y con un breve procedimiento administrativo para cada una de ellas, que permite a las leyes de esas otras Administraciones territoriales desarrollar sus propios procedimientos, con respecto siempre a los trámites básicos, para imponer las sanciones previstas en la RESA, e incluso crear otras sanciones distintas;

- una serie de leyes sectoriales de carácter administrativo, previas a la RESA, que han acuñado otros tipos de sanciones (en el amplio concepto que, de ellas, tiene el Derecho en el Reino Unido, offences), que casi siempre implican sanciones de tipo económico (penalties, fines ${ }^{73}$ ), aunque otras veces pueden acarrear penas de

72 Eso se debe, como afirma Betancor, A (2009), “Derecho Administrativo sancionador... opus cit., pp. 5 y 6, a que el término "sanction" en el Derecho británico hace referencia a cualquier forma de hacer cumplir la norma, cuando ésta queda vulnerada: “En nuestra terminología jurídica, estas ordenes no son estrictamente sanciones porque no se dirigen a castigar nada sino a hacer cumplir ciertos mandatos impuestos por la Ley. Es significativo que sean, en cambio, considerados como sanciones en el Derecho inglés. Esta interpretación se basa en que ambas surgen como consecuencia del incumplimiento de la regulación. Esta circunstancia no sería definitiva para considerarlas, en nuestro Derecho, como sanciones, sino como consecuencias accesorias al castigo.".

73 Por ejemplo, la Planning Act de 2008 tipifica como offence la construcción de desarrollos urbanísticos sin licencia (art. 160), y los sanciones con multas (fines) de hasta 50.000 libras. También el art. 168 tipifica como infracción la denegación de respuesta por los administrados a las peticiones de información realizadas por la Administración, previstas en el art. 167. Otra ley reciente, aunque previa a la RESA, de la importancia de la Natural Environment and Rural Communities Act 2006, capítulo 16, también ha recogido como infracciones los daños a la fauna y sus ecosistemas, en sus arts. 43, 50, 53, 55, etc. También ha tipifi-

126 Traffic Management Permit Scheme en las autopistas inglesas.

Documentación Administrativa 
cárce ${ }^{74}$ (siendo en este caso criminal offences, o delitos); en todo caso, al ser sanciones impuestas por jueces y tribunales (courts), carecen de procedimiento administrativo;

- las futuras leyes posteriores a la RESA, que pueden elegir entre imponer las sanciones previstas en la misma, remitiéndose a ella y a los trámites procedimentales en ella previstos para su imposición, o crear otras sanciones administrativas con sus respectivos procedimientos.

Como vemos, la RESA sólo vincula a las leyes posteriores cuando éstas prevén el uso de sus sanciones para las infracciones que se produzcan de las mismas, pero no cuando opten por tipificar sanciones distintas, con sus respectivos procedimientos. Tampoco vinculan a las leyes previas, cuyas infracciones pueden ser sancionadas con sus propias sanciones a través de sus propios procedimientos, si bien las Agencias o Administraciones encargadas de sancionar esas infracciones pueden escoger también el uso de las sanciones previstas en la RESA, en cuyo caso deben someterse a las obligaciones y a los trámites procedimentales en ella recogidos.

En el Reino Unido, por tanto, en materia de distribución competencial de la potestad sancionadora, ocurre algo parecido a lo que acaece en España: se trata de una competencia adjetiva que sigue a la competencia sustantiva y a su titular, de forma que si en España la competencia en materia de seguridad ciudadana es estatal, también es estatal la regulación de sus infracciones y sanciones. De la misma forma, las competencias propias y en las transferidas o devueltas a Gales, Escocia o Irlanda del Norte, incluyen la regulación de sus infracciones y sanciones, y sólo en la medida en que esas Administraciones pretendan usar las sanciones de la RESA deberán someterse a ella.

\section{La flexibilidad como objetivo principal del nuevo régimen jurídico de la potestad sancionadora en el Reino Unido}

Ya se ha comentado arriba la paradoja que para nosotros supone que en el Derecho británico las sanciones administrativas se denominan civil sanctions (y no administrative sanctions) por contraposición a las penal sanctions o delitos: y ello porque expresiones como Administration o administrative no tienen tradición jurídica y son recién llegadas en el rule of law. Pues bien, la razón de ser de esta Tercera Parte de la RESA es otorgar a los regulators (Agencias) un variado aparato sancionador, en un sentido muy amplio, tanto que algunas de las civil sanctions que ahí se recogen no se podrían reputar como sanciones administrativas en nuestro Derecho administrativo sancionador, como se ha dicho. El principal rasgo de esas civil sanctions es su flexibilidad, de forma que el mismo tipo de sanción pueda adaptarse a cada caso concreto, lo que supone una plasmación del principio de proporcionalidad, tan importante en la potestad sancionadora. Con ese nuevo aparato sancionador la RESA pretende, así, poder sancionar a aquéllas

74 Así ocurre, por ejemplo, con las infracciones más graves recogidas en la Road Traffic Regulation Act de 1984 . 
empresas que por lo general son cumplidoras de la normativa pero que hayan podido infringir puntualmente la ley, $y$, al mismo tiempo, castigar con toda la dureza posible a aquellas otras empresas que fuesen infractoras contumaces, a las que se las puede privar de los beneficios que han obtenido de las infracciones cometidas (y que las colocan ilegalmente en una posición de mercado ventajosa frente a sus competidoras cumplidoras), obligar a restaurar el daño producido, indemnizar a las víctimas e incluso imponer medidas preventivas de nuevas infracciones.

\section{Tipología de las sanciones previstas en la Parte III de la RESA}

La Parte Tercera de la RESA supone la transposición a nivel legislativo de las recomendaciones del Informe Macrory que hemos visto arriba. En la RESA no sólo se recogen diferentes tipos de sanciones, sino un breve procedimiento para su imposición, que no es común a todas ellas, pero sí muy parecido, y que sigue, grosso modo, las exigencias previstas en los apartados $20^{\circ}$ y $3 .^{\circ}$ del art. 6 del Convenio Europeo de Derechos Humanos, suscrito por el Reino Unido en $1951^{15}$, y cuya letra, y la interpretación que de la misma hace el TEDH, ha tenido un gran impacto en las últimas décadas en las garantías de los acusados en el procedimiento administrativo sancionador británico, si bien superponiéndose a las exigencias de procedimiento del due process of law, acuñados intemporalmente a lo largo de los siglos por el Common Law, como se ha visto. Volveremos más adelante sobre el impacto que el CEDH ha tenido en el aumento de las garantías formales y materiales de la potestad sancionadora.

En fin, la RESA otorga a las Agencias los siguientes instrumentos sancionadores:

75 El art. 6 CEDH se refiere a los derechos procesales de los acusados frente a infracciones penales y a la necesidad de un juicio justo para ser condenado, pero, al igual que ocurre en el Derecho continental, también ha acabado influyendo en el procedimiento administrativo sancionador en el Reino Unido. Sus apartados $2 .^{\circ}$ y $3 .^{\circ}$ dicen así:

"2. Toda persona acusada de una infracción se presume inocente hasta que su culpabilidad haya sido legalmente declarada.

3. Todo acusado tiene, como mínimo, los siguientes derechos:

- A ser informado en el más breve plazo, en una lengua que comprenda y detalladamente, de la naturaleza y de la causa de la acusación formulada contra él.

- A disponer del tiempo y de las facilidades necesarias para la preparación de su defensa.

- A defenderse por si mismo o a ser asistido por un defensor de su elección y, si no tiene medios para pagarlo, poder ser asistido gratuitamente por un abogado de oficio, cuando los intereses de la justicia lo exijan.

- A interrogar o hacer interrogar a los testigos que declaren contra el y a obtener la citación y el interrogatorio de los testigos que declaren en su favor en las mismas condiciones que los testigos que lo hagan en su contra. la audiencia.".

- A ser asistido gratuitamente de un intérprete, si no comprende o no habla la lengua empleada en

Hasta la Ley de Derechos Humanos de 1998 (Human Rights Act 1998), las violaciones de los derechos del CEDH por las Administraciones británicas sólo eran enjuiciables ante el TEDH de Estrasburgo. Una vez entrada en vigor esa Ley, los propios Tribunales y jueces británicos pueden hacer valer esos derechos, "transpuestos" al derecho interno por la misma. Por lo tanto, cualquier demandante que interponga un recurso ante los Tribunales civiles o administrativos británicos frente a un sanción administrativa por vulneración los derechos y garantías del art. $6 \mathrm{CEDH}$, podrá exigir del Tribunal que tenga en cuenta los están128 incluso si la decisión de fondo va dirigida a la reinstauración o satisfacción de esos derechos. 


\section{A) Fixed monetary penalties}

\section{Concepto}

La RESA las concibe como sanciones en metálico por una cantidad prefijada, a imponer por las Agencias en casos de infracciones leves. Son poco comunes en nuestro Derecho Administrativo sancionador, más proclive a determinar discrecionalmente la cuantía de la multa entre unas cantidades límite preestablecidas en las leyes.

Este tipo de sanciones administrativas están previstas en la RESA para castigar conductas de baja intensidad infractora, como podría ser el que una empresa se quedara por debajo de los estándares establecidos por las leyes ambientales. La cantidad que se impone a modo de sanción es, por ello, también escasa. Con ello se consigue evitar el estigma que, hasta la aprobación de la RESA, suponía tener que castigar como delitos las infracciones menores a la normativa, lo que parece a todas luces desproporcionado, Esto, en España, además, supondría una infracción del principio de ultima ratio del Derecho penal.

\section{Atribución de la potestad}

La potestad sancionadora prevista en la RESA deberá ser atribuida, por lo general, a cada Agencia, a través de una Orden Ministerial. La Orden ministerial que atribuya la potestad sancionadora para imponer una multa económica prefijada debe hacerlo para un solo caso, y siempre que la Agencia tenga la certeza de que la empresa cometió realmente la infracción (art. 39.2). La cantidad de la sanción viene establecida también en esa Orden ministerial, así que su imposición es reglada. Eso sí, aunque preestablecidas, la Orden ministerial puede discriminar según el tipo de empresa infractora (de modo que a un empresario individual se le puedan poner 100 libras esterlinas de sanción y a una empresa 150, por ejemplo) o según el tiempo en que la infracción ha estado cometiéndose (si una semana, 100 libras, si dos semanas, 150, por ejemplo), pero nunca existirá discrecionalidad a la hora de aplicarlas, debiendo limitarse la Agencia a seguir los supuestos de hecho y a anudarles la sanción prevista para cada uno de ellos.

\section{Procedimiento}

El art. 40 de la RESA establece un procedimiento ${ }^{76}$ para la imposición de estas multas de cantidad fija, que comienza con la notificación al infractor de una notice of

76 Aunque no se trata de un procedimiento acabado sino más bien de trámites esenciales, muy al estilo británico, la exigencia de procedimiento previo para el ejercicio de acciones de enforcement es común en el Reino Unido y en España, donce nuestro art. 134 LRJAPyPAC lo deja bien claro. Las posibles lagunas de estos miniprocedimientos previstos en la RESA para la imposición de cada una de sus sanciones se 
intent. Se trata de una especie de carta de intenciones (letter of intent), una figura jurídica muy conocida del Common law, en la que alguien comunica al otro su intención de hacer algo si la contraparte no actúa en consecuencia. Normalmente, la advertencia consiste en tomar acciones jurídicas en el asunto y demandar a la otra parte para pedirle responsabilidad por daños provocados o para demandarla penalmente por la comisión de una infracción penal (to sue o to prosecute, respectivamente) advertencia que en la RESA queda demudada en notice of intent, lo que bien podría traducirse como orden-requerimiento-aviso de intenciones, lo que le añade un matiz inquisitivo más propio de una Administración. La notice of intent emitida por la Agencia tiene un contenido obligatorio y debe incluir:

— La sanción que se propone imponer;

— los motivos por los que se propone imponer la multa;

- la posibilidad que tiene la empresa de realizar un pago adelantado de la misma (discharge payment), que supondrá la extinción de su responsabilidad, el plazo en que podría hacerlo (nunca superior a 28 días a contar desde el día en que se recibe la notice of intent ${ }^{77}$ ), y los efectos que tendría sobre su responsabilidad ${ }^{78}$;

- el derecho de la empresa a hacer alegaciones (representations) y objeciones contra la sanción propuesta, y el plazo del que dispone para ello, nunca más de 28 días; este plazo puede parecernos escaso pues, como ocurre en España, se exige un alto nivel de diligencia a los sujetos responsables de infracciones administrativas para poder alegar a su favor la falta de culpabilidad;

- las circunstancias por las que la Agencia no podría imponer la sanción (por ejemplo, en caso de que la empresa tenga una razón de peso para haber infringido la ley, o en caso de fuerza mayor). Al igual que ocurre en nuestro Derecho sancionador, para poder castigar una infracción administrativa se necesita, como mínimo, una actitud culposa o negligente de la empresa (principio de culpabilidad), de forma que antes de la imposición de cualquier sanción prevista en la RESA, la empresa podrá alegar la concurrencia de alguna circunstancia extintiva de su responsabilidad administrati-

puden rellenar con la jurisprudencia recaída (Case Law) sobre temas civiles (lo que incluye los asuntos administrativos, ya que la jurisdición civil británica se entiende sólo en contraposición de los temas penales o criminales). También la interpretación que el TEDH ha hecho del art. 6 del CEDH ha ayudado a implementar las garantías del imputado administrativamente en el Reino Unido. Como se verá, la RESA no recoge algunos de los trámites esenciales que sí entiende necesarios el Derecho sancionador español, como la separación entre la instrucción y la resolución, el principio de acceso permanente al expediente administrativo, etc.

77 En la RESA los plazos impuestos por la Ley a los administrados empiezan a contar desde el mismo día en que reciben la notificación, a diferencia de lo que ocurre en nuestra LRJAPyPAC, que comienza a contar desde el día siguiente.

78 En las fixed monetary penalties ya impuestas, el 40\% de las empresas se acogió a este pago libe-

130 REFORM, Impact Assessment... opus cit., mayo de 2008, p. 33. 
va (por analogía con nuestro Derecho sancionador en España podríamos nombrar la fuerza mayor o el error invencible, incluso el principio de confianza legítima en las Administraciones Públicas). El presunto infractor tiene la carga de probar esas circunstancias eximentes o atenuantes de su responsabilidad, algo que no contradice el principio de presunción de inocencia.

Se observa que el contenido de la notice of intent, en parte, se asemeja al acto administrativo de iniciación del procedimiento sancionador ${ }^{79}$, por lo que cabe hacer un paralelismo entre ambas. Al igual que ocurre en nuestro Derecho Administrativo, el acuerdo de iniciación del procedimiento administrativo sancionador contra alguien constituye una acusación formal, y, al notificarse, satisface su derecho a ser informado de la misma.

Una vez notificada la notice of intent, y no habiéndose acogido la empresa a la posibilidad del pago adelantado (discharge payment ${ }^{80}$ ), la empresa tendrá derecho a hacer sus alegaciones y objeciones, y a plantear excusas para su defensa (se sobreentiende que también podrá proponer la práctica de pruebas), que tras ser recibidas y tenidas en cuenta por la Agencia, deberán ser contestadas por ésta a modo de final notice (en el sentido de ratificarse en la propuesta de la sanción, de modificarla), o archivarla ${ }^{81}$. También en esto se asemeja el procedimiento administrativo sanciona-

79 En ese acto administrativo de trámite, conforme al art. 13 Real Decreto 1398/1993, de 4 de agosto, por el que se aprueba el Reglamento del procedimiento para el ejercicio de la potestad sancionadora, en adelante RPEPS), la Administración debe identificar a la persona o personas presuntamente responsables; describir los hechos sucintamente expuestos que motivan la incoación del procedimiento, su posible calificación y las sanciones que pudieran corresponder, sin perjuicio de lo que resulte de la instrucción; nombrar a un instructor del procedimiento y, en su caso, un secretario del procedimiento, con expresa indicación del régimen de recusación de los mismos; determinar el órgano competente para la resolución del expediente y la norma que le atribuya tal competencia, indicando la posibilidad de que el presunto responsable pueda reconocer voluntariamente su responsabilidad, con los efectos previstos en el artículo 8 del RPEPS; las medidas de carácter provisional que se hayan acordado por el órgano competente para iniciar el procedimiento sancionador, sin perjuicio de las que se puedan adoptar durante el mismo de conformidad con el artículo 15 RPEPS; y, finalmente, la indicación del derecho a formular alegaciones.

80 El pago adelantado supone que la empresa acepta su responsabilidad y que renuncia, pues, a hacer alegaciones y/u objeciones a la propuesta de sanción. Este pago extingue su responsabilidad y paraliza el procedimiento sancionador. La cantidad de este pago queda determinada discrecionalmente por la Agencia, y suele ser siempre inferior o igual a la propuesta, nunca superior. Es aconsejable rebajar considerablemente la cuantía de la sanción propuesta, en proporción al ahorro en personal y tiempo que le supone a la Agencia no tener que seguir tramitando el procedimiento sancionador, y como una forma de estimular la asunción de su culpa por parte de las empresas infractoras.

81 Es interesante resaltar que la propia RESA (art. 40.4, a) aconseja a la Agencia no imponer finalmente la sanción si tiene la certidumbre o el convencimiento de que la empresa infractora no sería responsable de la infracción por la vía penal. Se trata de una condición muy genérica que es usada en otras ocasiones por la RESA para indicar que sólo deberán imponerse sanciones administrativas cuando la Administración dispusiera de pruebas e indicios convincentes que permitirían condenarla en el rígido y garantista proceso penal británico. Con ello se le viene a decir a la Agencia que no imponga sanciones sin haber realizado previamente una fase probatoria (aunque no aparece expresamente como tal en la Parte Tercera de la RESA debe entenderse implícita), o que luego no va a poder demostrar, lo que revela en la práctica que la ratio y el sentido de las sanciones administrativas es igual de serio y exigente que el de los delitos, y que, por tanto, son alternativas a usar por la Administración, como es el propósito general de la 
dor en el Reino Unido y en España, ya que en nuestro país, tras el acuerdo de iniciación del procedimiento sancionador, el acusado puede realizar alegaciones, presentar documentos y proponer pruebas.

Si la Agencia decide imponer la sanción (modificada o no), debe emitir una final notice, en la que se le notifica a la empresa su decisión de imponer finalmente la sanción, y cuyo contenido se recoge en el art. 40.5 RESA:

- Los motivos para imponer la sanción (se entiende que matizados después de haber sido oída la empresa y ratificados o no los hechos después de haberse practicado la prueba pertinente) $)^{82}$; lo fundamental en este apartado es motivar adecuadamente la sanción impuesta.

— la forma en que puede ser hecho el pago, y el plazo para hacerlo;

- la posibilidad de acogerse, cuando existiera, a descuentos por un pago voluntario previo;

- la existencia de recargos por pago tardío o fuera del plazo preestablecido;

— su derecho a recurrir judicialmente la sanción y

- las consecuencias que tendría para la infractora no pagar la sanción.

La final notice podría hacerse equivaler, salvando las distancias, a la propuesta de sanción prevista en nuestro procedimiento administrativo sancionador, si bien, mientras que en España su notificación permite al acusado volver a realizar alegaciones, previo acceso al expediente (trámite de audiencia), en UK no ocurre lo propio.

\section{Su ejecución forzosa}

En el incipiente Derecho administrativo británico hasta hace bien poco aún no existía un procedimiento para la ejecución forzosa de los actos administrativos, razón

Parte Tercera de la RESA. Se trata de una plasmación formal del principio de presunción de inocencia, que exige prueba de cargo de la Administración para poder sancionar.

Para ayudar a la Agencia a imponer la sanción, el art. 70 le otorga el derecho a acceder a la información de que dispusiera la policía sobre el comportamiento de la empresa presuntamente infractora, siempre que con ello no se violen datos íntimos.

82 Cfr. Wade, W. y Forsyth, C. (2000), opus cit., pp. 377 y 378 . Conforme a estos autores, la motivación de los actos administrativos en el Derecho británico debe basarse en la doctrina de las llamadas "relevant and irrelevant considerations". Un ministro o cualquier otra autoridad administrativa abusa de la discrecionalidad y del principio de razonabilidad cuando motiva un acto en consideraciones o razones que no estaban previstas en la ley o reglamento, o cuando no atiende en las mismas a los intereses de todos los interesados. La motivación debe ser especialmente adecuada en los potestades administrativas discrecio-

132 nales, tanto más cuanto más amplia sea; o en aquéllas de gravamen, que infligen un daño no antijurídico a los administrados, como ocurre con la potestad sancionadora. 
por la cual las sanciones impagadas por una empresa, hasta ahora, no podían ser ejecutadas sobre la base del principio de autotutela, como ocurre en nuestro país, sino sobre la heterotutela de los Tribunales civiles, a través de un proceso de ejecución de deuda. Ambos sistemas conviven todavía actualmente ${ }^{83}$, como vamos a ver (véase el art. 52.2 RESA), si bien la tendencia es que el Ministro otorgue la potestad de ejecución forzosa en la Orden ministerial por la que concede la potestad sancionadora a una Agencia. El procedimiento para cobrar las sanciones impagadas difiere si previamente la empresa apeló o no la sanción impuesta:

- Si la empresa recurrió judicialmente la sanción impuesta y el Tribunal de primer nivel, o de primera instancia (First-tier Tribuna/ ${ }^{84}$ ), encargado de resolverla, desestima ese recurso y da la razón a la Agencia, la sanción podrá ser ejecutada directamente por la Administración, puesto que ya dispone de un título ejecutivo para ello: las decisiones de este Tribunal son asimilables a los autos de una County Court o de la High Court en Inglaterra y Gales, o de los Tribunales homólogos en Escocia e Irlanda del Norte, encargados de la ejecución de deudas líquidas ${ }^{85}$.

- Si la empresa no apeló la sanción impuesta pero no la paga, entonces la Agencia deberá seguir un proceso judicial especial para poder recuperarla, que se inicia con una demanda (claim) ante los Tribunales civiles (civil courts). Pero como este proceso puede ser laborioso, la RESA y la Tribunals, Courts and Enforcement Act de 2007 (en adelante TCEA) han permitido que la Orden Ministerial que adjudica la potestad sancionadora a la Agencia pueda atribuirle también poderes especiales para ejecutar forzosamente por sí misma las sanciones impagadas, como si fueran títulos ejecutivos sancionados por un Tribunal de justicia (Court order). Aún así, esta especie de procedimiento de ejecución forzosa por parte de las Agencias no es puramente administrativo, ya que deberá seguir los trámites del proceso civil ${ }^{86}$, en el que la inten-

83 Las deudas con la Administración pueden ser ejecutadas por ésta ante los Tribunales civiles, sometiéndose a las Partes 70-74 de las Civil Procedure Rules 1998. Cfr. MINISTRY OF JUSTICE (2009), Guidance on creating new regulatory penalties and offences, 26 de enero de 2009, p. 5.

84 El First-tier Tribunal es un nuevo Tribunal con competencia universal o general en el Reino Unido, creado por la Tribunals, Courts and Enforcement Act de 2007 (en adelante TCEA). Su función principal es resolver las apelaciones interpuestas por los administrados contra determinadas decisiones del Gobierno. Esta ley ha creado también un Upper Tribunal (o Tribunal de segunda instancia, o superior), para resolver las apelaciones contra las decisiones del First-tier Tribunal.

85 Cfr. art. 27 de la Tribunals, Courts and Enforcement Act 2007. En el Reino Unido un Tribunal tiene un rango inferior a un Court, pues aquéllos son organismos judiciales creados por ley parlamentaria para entender de disputas y litigios de orden administrativo, social, laboral, etc., siendo los más importantes los administrative tribunals y los industrial tribunals. Se caracterizan por su flexibilidad, y por la rapidez y sencillez de sus procedimientos y contra sus resoluciones se puede invocar la doctrina jurisprudencial del ultra vires (abuso de competencia o incompetencia) y del recurso de error on the face of the record (error en el sumario, o falta de procedimiento) para que resuelvan instancias judiciales superiores, como por ejemplo el Upper Tribunal, también creado por esa ley. Una Court, sin embargo, es un Tribunal de Justicia, con procesos más complejos y garantistas.

86 Rule 70.5 de las Civil Procedure Rules de 2008 (Enforcement of decisions of bodies other than the High Court and the county courts and compromises enforceable by enactment), que pueden consultarse en http://www.justice.gov.uk/civil/procrules_fin/contents/parts/part70.htm\#IDAKBO4B. En resumen, la Agen- 
ción final de la Agencia es conseguir un auto del Tribunal de Distrito con el que poder ejecutar la deuda en que consiste la sanción. Una vez obtenido ese auto, la Agencia dispone de varias opciones de ejecución, que podrá usar discrecionalmente (como discrecionalidad existe en el empleo de los medios de ejecución forzosa previstos en la LRJAPyPAC), si bien con algunos límites. Esas opciones son:

- Un embargo (warrant of execution), por la que un bailiff, o agente municipal especializado en embargos embarga bienes o dinero por el valor de la deuda;

- una garantía de pago (charging order), por la que la Agencia impone un gravamen sobre el patrimonio de la empresa infractora (la sede de la empresa, sus bienes muebles o inmuebles) como garantía de cobro de la sanción, o

- una orden de pago dirigida a terceros (third party debt order), para evitar que la empresa infractora alce sus bienes para evitar los otros dos medios de ejecución.

Por el empleo de estos medios de ejecución forzosa (que la RESA considera sanciones en sí mismos, sanctions), la Agencia deberá pagar una tasa, que podrá recuperar repitiéndosela a la empresa, cuando consiga ejecutarla.

Una vez que la Agencia haya cobrado la sanción impuesta, con todos sus recargos, está obligada a entregar e imponer el dinero en el Consolidated Fund ${ }^{87}$ (art. 69 RESA).

\section{El juego del principio non bis in idem}

Al ser las fixed monetary penalties sanciones por poca cantidad, la RESA considera que se pueden imponer con posterioridad a alguna sentencia penal en la que se casti-

cia debe solicitar al Tribunal de distrito en que tenga su sede social la empresa infractora una decisión judicial o auto (order), que puede incluso dictar un oficial del Tribunal (no necesariamente el Magistrado, o Judge) y sin audiencia de la empresa infractora. Una vez dictada, la Agencia puede proceder a ajecutarla forzosamente, aunque debe pagar una tasa por haber recurrido a los Tribunales, tasa que después repercutirá a la empresa infractora si consigue ejecutar la sanción exitosamente. De todas formas, los trámites que debe seguir la Agencia antes de solicitar el auto al Tribunal de Distrito varían dependiendo de lo que estableciese discrecionalmente la Orden ministerial, de forma que, a veces, el Ministro le impone a la Agencia que notifique a la empresa una segunda orden de pago o requerimiento (notice), si la empresa ignoró la originaria, incluyendo un recargo por pago tardío (late payment charge). Se trata de un tipo de recargo sencillo que no llega a tener la complejidad de los recargos previstos en nuestro ordenamiento jurídico por la Ley 58/2003, de 17 de diciembre, General Tributaria (arts. 163-173), y por el Real Decreto 939/2005, de 29 de julio, por el que se aprueba el Reglamento General de Recaudación (arts. 70-116), dentro del procedimiento de apremio sobre el patrimonio, para ejecutar deudas líquidas en las que la acreedora es una Administración Pública. Si la empresa infractora se negara a pagar la sanción a la vista del segundo requerimiento notificado, entonces la Agencia podrá solicitar el auto de ejecución que acabamos de ver al Tribunal de Distrito, una vez pasado el plazo que se establezca en la Orden ministerial.

87 Se trata de la cuenta general que tiene el Tesoro en el Banco Central de Inglaterra, en la que

134 carga todos sus gastos e ingresa todos sus haberes. 
gue con el pago de una cantidad de dinero sin que por ello se incurra en vulneración del principio non bis in idem, con el límite de que la cantidad a cobrar por aquélla nunca podrá superar la cantidad cobrada como multa por la vía penal (art. 39.4 RESA). Es una interpretación laxa y material de un principio que en nuestro país es mucho más dogmático y formalista, y que muy probablemente impediría esta doble sanción por el mismo hecho, independientemente de la cantidad económica cobrada originalmente ${ }^{88}$.

Resulta curioso que mientras que la RESA permite compatibilizar la imposición de sanciones económicas prefijadas con sentencias penales por la misma infracción, no permite la imposición simultánea o consecutiva de diversas sanciones administrativas para la misma infracción. Así, la Agencia no puede imponer una fixed monetary penalty si previamente ya hubiese recaído un discretionary requirement, habida cuenta del importante gravamen que éste suele suponer para la empresa infractora. También está prohibido lo inverso, es decir, que la Agencia imponga un discretionary requirement si previamente ya existía una sanción económica prefijada. Tampoco es posible imponer consecutivamente una sanción económica prefijada y una stop notice (art. 51 RESA). La razón material de esa aparente incongruencia es que la sanción penal compatible con la sanción económica es también una sanción económica (si bien penal), mientras que la combinación de diversas sanciones administrativas por la misma infracción supone la imposición a la empresa infractora de diferentes deberes jurídicos. Se trata de una excepción al principio de non bis in idem que no podemos hacer en España, ex art. 133 LRJAPyPAC, pero al que no le falta sentido en su fondo.

\section{La preferencia temporal de las sanciones administrativas sobre las sanciones penales}

Otro aspecto que puede chocar al jurista español es que existe una especie de preferencia temporal de la sanción administrativa a la penal, impidiendo la RESA iniciar un proceso penal antes de que expire el plazo del que dispone el infractor para extinguir su responsabilidad mediante un pago anticipado, el cual, en caso de producirse, impediría además perseguir por la vía penal a la infractora, por la misma infracción. Al contrario, en el Derecho sancionador español, cuando al hilo de la tramitación de un procedimiento administrativo sancionador el instructor estimase que existen indicios de delito, debe dar trámite al Ministerio fiscal e inhibirse hasta que se pronuncie la jurisdicción penal, en su caso $^{89}$. Esa preferencia de lo administrativo a lo penal se traduce en la RESA, además, en que cabe imponer una fixed monetary penalty después de haber recaído una sentencia penal condenatoria (conviction), pero no al revés (art. 41, b). No obstante, al margen de la

88 La única forma de salvar esa prohibición en nuestro Derecho Administrativo sancionador sería entender que existe un distinto fundamento para imponer sendos castigos (verbigracia, si el delito castiga un vertido de una empresa por atentar contra la salud pública, y la infracción administrativa hace lo propio por atentar contra el medio ambiente) (art. 133 LRJAPyPAC). En otro caso, si el fundamento jurídico fuera el mismo, conforme a nuestro Derecho sancionador, debería prevalecer siempre la norma penal.

89 Si se estima que existe identidad de sujeto, hecho y fundamento entre la infracción administrativa y la infracción penal que pudiera corresponder, el órgano competente para la resolución del procedimiento acordará su suspensión hasta que recaiga resolución judicial (art. 7 RPEPS). 
especialidad de la RESA, la regla general de los procedimientos administrativos instruidos en el Reino Unido por inquiries es también la de la suspensión del procedimiento administrativo cuando surjan indicios de responsabilidad penal90.

La Memoria Económica de la RESA prevé que el 50\% de las sanciones administrativas que se han de imponer en el futuro sean fixed monetary penalties ${ }^{91}$, estimación que está basada en los datos de las sanciones ya impuestas.

\section{B) Discretionary requirements}

\section{Concepto}

Los "requerimientos discrecionales" son un conjunto de sanciones posibles, que pueden imponerse individualmente o en conjunción con otras, y que están pensadas para infracciones graves o muy graves, a diferencia de las fixed monetary penalties. Su principal característica es su flexibilidad, lo que las hace especialmente apropiadas para casos de infracciones complejas, con multitud de efectos en la esfera de derechos de los interesados y frente al interés público.

\section{Atribución de la potestad}

La facultad de imponer estos discretionary requirements la otorga el Ministro a la Agencia en su Orden ministerial de atribución de la potestad sancionadora. La misma Orden puede permitirle a la Agencia usar varios tipos de Discretionary requirements a la vez, en cuyo caso será discrecional de la misma decidir usar cualquier de esos medios aisladamente o en combinación con otros. Es en estos casos cuando las civil sanctions (sanciones administrativas) recogidas en la Parte Tercera de la RESA se muestran con toda su fuerza como alternativa a las sanciones penales, mucho más rígidas y con menos capacidad de controlar y compensar todos los efectos lesivos que puede acarrear una infracción de la ley.

\section{Procedimiento}

El procedimiento para imponer cualquier sanción incluida dentro de los discretionary requirements es similar al que ya hemos expuesto para imponer una fixed mone-

90 Si atendemos a lo que dice la Inquiries Act de 2005, en su art. 13.1, b), el Ministro que conduce un procedimiento administrativo con implicaciones para los intereses públicos (inquiry, v.gr., una licencia de construcción, una expropiación, etc.) puede suspender ese procedimiento para determinar la responsabilidad civil o penal (incluso disciplinaria) que pudiera surgir de la tramitación del mismo. También podría suspenderlo hasta terminar otras investigaciones administrativas relacionadas con el objeto de ese procedimiento. De todas formas, la suspensión de la inquiry requiere en el Reino Unido unas garantías adicionales, vista su excepcionalidad, que no son parangonables en nuestro Derecho Administrativo: consultar al titular del órgano administrativo (chairman) y notificar esa suspensión al Parlamento inglés (o a la Asamblea legislativa galesa, irlandesa o escocesa, si fuere el caso).

91 Cfr. BERR (2008), DEPARTMENT FOR BUSINESS ENTERPRISE AND REGULATORY REFORM, Im-

136 pact Assessment... opus cit., mayo de 2008, p. 32. 
tary penalty, de forma que, en primer lugar, será necesario que la Agencia emita una notice of intent, y que la notifique a la empresa infractora, con el contenido mínimo que ya hemos comentado. Luego, la empresa o persona infractora podrá realizar alegaciones, objeciones y defenderse de la sanción que la Agencia propone imponerle; pasado el plazo para hacerlo, habiendo o no la empresa usado su derecho para defenderse, la Agencia decide finalmente si emitir o no una final notice, imponiendo el/los discretionary requirement/s (modificado/s tras las alegaciones recibidas, o no) ${ }^{92}$.

La final notice debe tener el siguiente contenido mínimo:

- los motivos para imponer la sanción y su cuantía (si fuese una multa);

- si se impusiera una multa económica de cantidad variable, debe indicarse cómo debe realizarse el pago, el plazo para hacerlo, y, en su caso, la posibilidad de acogerse a un pronto pago que extinga la responsabilidad, junto con la advertencia de que pagar fuera del plazo establecido podría acarrear recargos en la multa;

- el derecho a recurrir, y

- las consecuencias que traería consigo para la empresa no cumplir con el discretionary requirement.

Una Agencia sólo puede imponer una sola vez un discretionary requirement para una misma infracción (art. 42.4 RESA). Las Agencias pueden adoptar requerimientos discrecionales de imposición de deberes a los infractores que pueden ser de diferentes tipos:

\section{Tipos de discretionary requirements}

A) Las «variable monetary penalties»

\section{Concepto}

Son sanciones económicas cuya cuantía queda determinadas por cada Agencia dependiendo de las circunstancias concretas de cada infracción, dentro de los límites

92 EI BERR (2008), DEPARTMENT FOR BUSINESS ENTERPRISE AND REGULATORY REFORM, Regulatory Sanctions Act 2008, Guidance to the Act, julio 2008, en su p. 37, aboga de forma voluntaria por una especie de división entre la fase de instrucción y la fase decisoria, de forma distinta a como se plantea en nuestro RPEPS, pero con la misma finalidad. Así, dice que la Agencia debe proveer para que, una vez emitida la notice of intent y escuchadas las alegaciones y objeciones de la infractora, sea otro funcionario más experto y con más experiencia en el sector de regulación (senior officer) en el que ha recaído la infracción, el que decida si adopta o no (y en qué medida) la resolución de imposición final de la sanción a través de la final notice, una vez vistas las circunstancias del caso, de forma que se promueva una mayor objetividad y calidad en el ejercicio de la potestad sancionadora. Se trata de una mera recomendación, ya que no aparece en el procedimiento sancionador previsto en el art. 43 RESA para imponer los discretionary requirements. 
de una horquilla de sanciones económicas preconfiguradas en la Ley. Las circunstancias que usan las Agencias para modular la cantidad de sanción que imponen suelen ser tres: las posibles ganancias económicas que la infracción le ha reportado a la empresa infractora, la gravedad de la infracción y el historial de incumplimientos de la empresa (history of compliance, que podríamos reconducir, grosso modo, a nuestro concepto de reincidencia, y, en un sentido más amplio, al de reiteración).

Ya hemos explicado arriba qué circunstancias suele tener en cuenta la Agencia para determinar la multa. No obstante, habida cuenta de que el Derecho administrativo británico pone mucho énfasis en la predecibilidad de las conductas administrativas, ha insertado en el procedimiento la obligación de que cada Agencia publique, antes de empezar a ejercer su potestad disciplinaria otorgada por Orden ministerial, una guía incluyendo los factores y circunstancias agravantes y atenuantes de las que piensa servirse para determinar las sanciones. Esto es especialmente importante cuando se trata de variable monetary penalties, cuya modulación siempre tiene un importante margen de discrecionalidad administrativa ${ }^{93}$. Las circunstancias agravantes y atenuantes de la responsabilidad del infractor llegan a un detalle mayor de lo que establece nuestro art. 131 LRJAPyPAC, cuyos tres elementos parecen estar desplegados y desarrollados en la Guidance to the Act que la BERR ha publicado para explicar la RESA ${ }^{94}$.

\section{Ejecutoriedad y non bis in idem}

Si la empresa infractora se negara a pagar la multa, lo que nunca puede hacer la Agencia es denunciarla para que sea perseguida criminalmente, algo que en Derecho inglés está prohibido por el principio de la double jeopardy (prohibición de volver a ser enjuiciado por una infracción ya sancionada, non bis in idem), ex art. 44.2 RESA. Lo

93 En el Derecho Administrativo continental este servicio lo presta la vinculación al precedente, si bien exige que la Administración haya tenido un largo recorrido para poder acumular un número de pronunciamientos suficiente como para constituir una referencia para los administrados, y, además, tiene el problema de que no existe la obligación de publicarlos para que sean conocidos por el público, a diferencia de lo que ocurre con estas guías (guidance) en el Reino Unido, que deben ser publicadas en el Diario Oficial correspondiente a cada Agencia.

94 Entre las circunstancias agravantes que propone la BERR, p. 38, están las siguientes: la gravedad del incumplimiento (por ejemplo, el daño producido a la salud humana o al medio ambiente, la duración de la conducta infractora, etc.), el historial de incumplimientos de la empresa (reincidencia), las ganancias económicas que, para la empresa infractora, se han derivado de la infracción, la conducta de la empresa tras el descubrimiento de la infracción por la Agencia, y las acciones previas adoptadas por la Agencia (u otras Agencias) para ayudar a la empresa a no incumplir la ley. Entre las circunstancias atenuantes podrían citarse: la existencia de un historial de cumplimiento de la normativa por parte de la empresa, las acciones adoptadas para eliminar o reducir el riesgo de daño o el daño en sí mismo derivado de la infracción cometida, el hecho de que la empresa hubiera informado voluntariamente a la Agencia de su infracción, y la colaboración con la Agencia para afrontar los efectos nocivos de la misma. Resulta curioso, no obstante, que el primer criterio enumerado en nuestro art. 131.3 LRJAPyPAC, esto es, la existencia de inten-

138 BERR a las Agencias, si bien puede entenderse implícito, aunque no de forma plena, en algunos de ellos. 
mismo ocurre con las multas de cantidad económica fija (fixed monetary penalty), según el art. 41, b RESA. Como ya se dijo arriba en relación con las sanciones económicas prefijadas, la RESA subvierte la preferencia de la vía penal sobre la administrativa creando una especie de preferencia administrativa sobre la penal: ésa es su finalidad declarada, reducir el excesivo recurso que las Administraciones hacían a la vía penal y permitir a las Agencias que puedan optar entre delitos e infracciones administrativas, reputándose éstas en la RESA como mejores, más flexibles y justas que aquéllas.

Vemos que estas penalties son semejantes a nuestras sanciones económicas o multas, nuestra especie más común de sanciones administrativas, que quedan determinadas económicamente por el instructor del procedimiento sancionador entre unas cantidades máximas y mínimas recogidas en las leyes, teniendo en cuenta las circunstancias agravantes o atenuantes y sobre la base del principio de proporcionalidad.

\section{B) Las «compliance notices» 0 «compliance requirements»}

Son avisos u órdenes administrativas para que una empresa que ha incumplido la ley (offence of law, breach of law) adopte medidas concretas en un plazo de tiempo determinado para volver a cumplir la normativa infringida o para que no vuelva a cometerla en el futuro.

Podría decirse que cuando estas órdenes se limitan a obligar a la empresa infractora a que cese en una actuación infractora podrían equivaler a nuestras medidas provisionales y cautelares previstas en nuestro procedimiento administrativo sancionador (arts. 136 y 138.3 LRJAPyPAC, y 4.2, 13.1, e), 15 y 21.4 del Real Decreto 1398/1993, de 4 de agosto, por el que se aprueba el Reglamento del procedimiento para el ejercicio de la potestad sancionadora, RPEPS), aunque, por lo general, estas notices implican el deber para la empresa de tomar otras medidas de carácter más amplio y genérico que la del mero cese de la actividad infractora, medidas en positivo y no meramente negativas, como podría ser comprar el equipamiento de seguridad o ambiental adecuado para cumplir la ley, cambiar el proceso productivo o entrenar a su personal para que deje de realizar prácticas ilegales.

\section{C) Las «restoration notices» 0 «restoration requirements»}

\section{Concepto}

Se trata de avisos u órdenes administrativas para que una empresa infractora restaure el entorno a la situación inicial previa a la comisión de la infracción. En este último caso, es evidente que en nuestro Derecho Administrativo sancionador estas 
medidas no son sanciones en sí sino medidas accesorias a la sanción principal (art. 130.2 LRJAPyPAC y art. 22.1, a) RPEPS).

La expresión restoration implica una restitutio in pristinum en su sentido más amplio, de forma que a veces puede implicar una restitución in natura, por ejemplo, del área contaminada por la empresa que cometió una infracción ambiental; o económica, cuando, verbigracia, una empresa que ha vendido productos defectuosos se ve obligada a devolver el dinero cobrado por los mismos a sus clientes.

\section{El Juego del principio de non bis in idem}

Los discretionary requirements de carácter no económico (es decir, excluidas las variables monetary penalties), al tener un menor contenido punitivo que las multas, pueden ser perseguidos posteriormente como infracciones penales, sin que ello constituya double jeopardy para el Derecho inglés (art. 44.3 RESA). En esto, estos requirements no económicos se diferencian de las multas, donde el recurso a la vía penal estaba proscrito. La RESA sólo permite comenzar la vía criminal en ejecución de las sanciones administrativas impuestas por los discretionary requirements no económicos dentro de un plazo de tiempo determinado (art. 44.4), que no puede ser extendido a posteriori por vía de Orden ministerial, ya que supondría una retroactividad lesiva de los derechos del infractor, que contravendría el art. 7 de la Convenio Europeo de Derechos Humanos ${ }^{95}$.

La Memoria económica de la RESA prevé que el 15\% de las sanciones administrativas que se hayan de imponer en el futuro sean discretionary requirements de carácter no económico ${ }^{96}$, estimación que está basada en los datos de las sanciones ya impuestas.

\section{C) Las «stop notices»}

\section{Concepto}

Son avisos u órdenes administrativas dirigidos a una empresa infractora para que cese y no continúe con la acción u omisión indicada en la misma (y que supone

95 Antes de recurrir a la vía penal, la Orden ministerial de atribución de potestad sancionadora a una Agencia puede permitirle a ésta que imponga una multa frente al incumplimiento de un discretionary requirement de carácter no económico. Se denominan non-compliance penalties, o multas por incumplimiento (art. 45 RESA). En la Orden debe indicarse la cantidad de esa multa, entre unos topes máximo y mínimo, y la forma en que debe ser calculada, la obligación de notificar la imposición de esa nueva multa mediante notice, y el derecho a apelarla, si la empresa lo estima pertinente. Se asemeja más a una penalidad de la contratación administrativa que a una multa coercitiva, ya que no tiene por finalidad vencer la voluntad renuente de la infractora para que ejecute el deber jurídico impuesto por el discretionary requirement de carácter no económico.

96 Cfr. BERR (2008), DEPARTMENT FOR BUSINESS ENTERPRISE AND REGULATORY REFORM, Impact Assessment... opus cit.,, mayo de 2008, p. 32. 
una infracción), hasta que no haya adoptado una serie de medidas que reconduzcan esa acción u omisión a la ley, eliminando el daño o el riesgo de daño producido o reduciéndolo. También puede notificarse una stop notice a una empresa que pretenda iniciar en un futuro próximo una acción que la Agencia estima muy arriesgada o muy lesiva. En ambos casos, las medidas a adoptar por la empresa deben tener por sentido que la acción u omisión iniciada o que se pretende iniciar en un futuro próximo no vayan a infringir la Ley, y, por tanto, que no van a producir riesgos o daños a la colectividad o al medio ambiente. Se trata de medidas positivas que coadyuvan a que la acción se realice, no a prohibirla o detenerla sin más. Se trataría, por ejemplo, de que una empresa no realice vertidos a un río si antes no ha depurado sus efluentes, conforme a la legislación ambiental.

Esa acción u omisión deben estar causando serios daños o presentar un elevado riesgo de causarlo. Son parecidas a las medidas provisionales de nuestro procedimiento administrativo sancionador, en la medida en que intentan evitar que la conducta infractora pueda seguir dañando los intereses generales (arts. 4.2 y 15 RPEPS y art. 72 LRJAPyPAC). Podríamos reproducir aquí la equivalencia expresada arriba en relación con las compliance notices, si bien aquí las medidas a adoptar por la empresa van dirigidas exclusivamente al cese o interrupción de su conducta infractora.

Las Agencias suelen emplear stop notices cuando tienen la certeza o el convencimiento razonable de que la acción desarrollada o por desarrollar acarrea o puede acarrear un daño o riesgo significativo (serious harm) a la salud humana, al medio ambiente (incluyendo plantas y animales) o a los intereses económicos de los clientes, y que esa acción u omisión, además, constituye una infracción administrativa de las leyes. Vemos, por tanto, que el daño real o previsible debe ser cualificado, y que, además, no vale con una mera sospecha o posibilidad de que se produzca, sino que debe existir un riesgo significativo de que pueda acontecer (art. 46 , apdos. $4 .^{\circ}$ y $5 .^{\circ}$ RESA).

Si la empresa, una vez recibida la stop notice, actuara en consecuencia cumpliendo la normativa, la Agencia emitiría un certificado de cumplimiento (completion certificate). También puede la empresa solicitar ese certificado en cualquier momento, incluso si antes la Agencia no le había notificado una stop notice, en cuyo caso la Agencia dispondrá de 14 días para emitirlo.

\section{El juego del principio non bis in idem}

Al igual que ocurría con los discretionary requirements de carácter no económico, el incumplimiento de una stop notice puede ser perseguido criminalmente ${ }^{97}$, al

97 Un 10\% de las stop notices impuestas son perseguidas criminalmente. Cfr. BERR (2008), DEPARTMENT FOR BUSINESS ENTERPRISE AND REGULATORY REFORM, Impact Assessment... opus cit., p. 35 . 
considerar que no añade un nuevo gravamen, distinto al que ya debería haber existido si la empresa hubiera cumplido la normativa, por lo que no se da el fenómeno comentado de la double jeopardy. En particular, el incumplimiento de la stop notice, podría acarrarle a la empresa infractora, si así lo consideró la Orden ministerial, ser declarada culpable, en un juicio por un delito menor juzgado por un Tribunal sin jurado (summary conviction),y, por tanto, a pagar una multa de hasta 20.000 libras o cárcel por una duración de hasta 12 meses; o a cárcel por una duración de hasta dos años, con o sin multa, si fuera declarado culpable por un Tribunal con jurado presidido por un juez profesional (Judge). Lo que hace en este caso el art. 49 de la RESA es establecer una especie de presunción iuris tantum por la cual el incumplimiento de la stop notice supone un delito en sí mismo, en la que se presume la culpabilidad penal de la infractora ${ }^{98}$. De todos modos, en España nunca sería posible ejecutar el cumplimiento de las sanciones administrativas por la vía penal. Es una rémora histórica del rule of law británico, cuya jurisdicción penal se ha encargado tradicionalmente de la ejecución forzosa de los actos de gravamen de la Administración y de la revisión de esos mismos actos.

\section{Indemnizaciones procedentes en casos de daños provocados por la imposición de una stop notice inadecuada}

Otro tema interesante emerge cuando la Agencia hubiera impuesto una stop notice de manera equivocada, ilegal o irrazonable, causando pérdidas económicas a la empresa: se trataría de un supuesto de responsabilidad extracontractual de la Agencia, que las órdenes ministeriales suelen recoger, y que se da, sobre todo, cuando la Agencia hubiese perdido el recurso interpuesto por la empresa frente a la stop notice o frente a la desestimación de su solicitud de un certificado de cumplimiento, y el fundamento de la sentencia del Tribunal de primer nivel fuese que la sanción estaba equivocada, era ilegal, desproporcionada o irrazonable. No se daría la responsabilidad si el recurso fuese ganado por la empresa por meros motivos técnicos o por error o falta de procedimiento, que dejaran imprejuzgada la validez de las sanciones impuestas. Igualmente puede ser recurrida la decisión de la Agencia de no otorgar la responsabilidad o de la cantidad en que ésta se fijase. Esta responsabilidad implica el pago de una indemnización a la empresa a la que se hubiera impuesto una stop notice, cuantificada en una cantidad equivalente al daño y pérdidas sufridas (lost suffered), lo que podríamos denominar daño emergente. Si tras perder el recurso la Agencia decidiera no compensar a la parte privada, ésta podría apelar esa decisión, incluso

98 Aunque esa presunción pueda parecernos contraria a nuestro derecho fundamental a la presunción de inocencia, lo que realmente intenta la RESA en su art. 49 es imponer a la empresa infractora la carga de probar su inocencia, habida cuenta de que fue ella la que se buscó esa presunción al incumplir la infracción administrativa (la stop notice). Esa inversión de la carga de la prueba se produce en la jurisdicción penal, en la medida en que la sanción administrativa debe vincular, por su especialidad, a aquélla, de modo parecido a lo que prescribe el art. 4 de nuestra LECr, cuando obliga a quien corresponda (la Adminis142 tración o la jurisdicción contencioso-administrativa) a resolver las cuestiones prejudiciales a la vía penal cuando pudiesen resultar determinantes de la culpabilidad o de la inocencia del inculpado. 
podría apelar también la cantidad en que la Agencia concreta esa indemnización, si estimara que no se ajusta a la realidad (art. 48).

La Memoria económica de la RESA prevé que el $5 \%$ de las sanciones administrativas que se hayan de imponer en el futuro sean stop notices ${ }^{99}$, estimación que está basada en los datos de las sanciones ya impuestas.

\section{D) Enforcement undertakings}

\section{Concepto}

Se trata de compromisos de hacer (undertakings) voluntariamente aceptados a los que se obliga una empresa, respecto de la cual una Agencia sospecha razonablemente que ha cometido una infracción administrativa, a través de los cuales se obliga a tomar o adoptar las medidas recogidas en el mismo, de carácter correctivo de dicha infracción. No existe ninguna medida en nuestro Derecho Administrativo sancionador que le sea equiparable, ya que suponen una contractualización de la potestad, sancionadora, de muy improbable validez en nuestro Derecho Administrativo. A lo máximo que podríamos llegar en España es a determinar convencionalmente el monto de las indemnizaciones debidas a las víctimas de la infracción, siempre que ese importe no hubiese podido ser determinando en la misma resolución del procedimiento sancionador (art. 22.2 RPEPS), algo que es perfectamente posible dentro de los límites previstos en el art. 88 LRJAPyPAC, ya que esos acuerdos se limitan a determinar el quantum de una potestad discrecional cuyo contenido se impuso de manera pura mediante acto administrativo (la sanción y la decisión de indemnizar), por lo que el núcleo de la potestad no queda afectado por el pacto, sólo la medida en que se concreta la misma ${ }^{100}$.

Estos compromisos sirven para atenuar las posibles sanciones que la Agencia haya podido imponer a una empresa, si bien sólo pueden ser aceptados cuando la Orden ministerial que le atribuya la potestad sancionadora a la Agencia así lo permita. $\mathrm{Si}$, por ejemplo, una Agencia se había propuesto sancionar a una empresa con una multa económica variable, la empresa puede contraatacar, en el trámite de alegaciones, ofertándole un acuerdo a la Agencia por la que se obliga a compensar el daño causado a la víctima y a restaurar el entorno, en cuyo caso la Agencia puede rebajar la multa finalmente impuesta. El acuerdo no puede ofrecerlo la empresa después de que se le hubiera notificado la resolución de imposición de la sanción a través de la final notice. Tampoco puede ser impuesto por la Administración ${ }^{101}$.

99 Cfr. BERR (2008), DEPARTMENT FOR BUSINESS ENTERPRISE AND REGULATORY REFORM, Impact Assessment... opus cit., p. 32.

100 Sobre la validez de los conciertos o convenios de colaboración en los que se concreta la medida de obligaciones previamente establecidas por normas o actos administrativos, véase García de Enterría, E. y Fernández Rodríguez, T. M. (1998), Curso de Derecho Administrativo, Tomo I, Editorial Civitas, S.A., Madrid, octava edición, pp. 666 y ss.

101 También es posible que sea la misma empresa la que se acerque a la Agencia a celebrar el acuerdo. En cualquier caso, la Agencia nunca estará obligada a aceptar el acuerdo que aquélla le propone, aun- 
Fue el Informe Macrory el que introdujo las bases para este tipo de acuerdos, cuando se quejaba de la rigidez de las sanciones penales y de la falta de soluciones creativas para lidiar con las infracciones normativas. En su opinión, debía haber casos en que, si la empresa reconocía su responsabilidad, pudiera compensar los efectos lesivos de su infracción de manera innovativa.

Nos recuerda este tipo de acuerdos a la terminación convencional de procedimientos administrativos (como el previsto en los arts. 2.2, 8 y 11 del Real Decreto 429/1993, de 26 de marzo, por el que se aprueba el Reglamento de los Procedimientos de las Administraciones Públicas en materia de Responsabilidad Patrimonial, que puede proponerse en el trámite de audiencia), o a la avenencia del expropiado al precio ofertado por la Administración expropiante, y, en fin, a cualquier convenio de colaboración intraprocedimental de nuestro Derecho Administrativo.

\section{Contenido}

Y, ¿cuál puede ser el contenido posible de un enforcement undertaking? En el art. 50 de la RESA se dice que la empresa puede comprometerse a parar en su actividad infractora o a evitar que se repita (por ejemplo, reemplazando un equipo defectuoso y contaminante); a restaurar el medio o los derechos dañados a la situación previa a la infracción; a indemnizar a las víctimas afectadas por la infracción; o a adoptar cualquier otra medida que le permitiera la Orden ministerial en la que se le atribuía potestad sancionadora a la Agencia ${ }^{102}$.

\section{Publicidad}

Estos undertakings deben ser publicados para su general conocimiento (al igual que ocurre ya en nuestro país, por ejemplo, con los convenios de terminación convencional de procedimiento, los acuerdos voluntarios en materia ambiental o los mismos convenios urbanísticos, en los que la normativa autonómica exige la creación de Registros ad hoc) y, en caso de que fuesen correctamente cumplidos por las empresas firmantes, la Agencia debe emitir un certificado de cumplimiento (completion certificate), como hemos visto también en relación con las stop notices. En el momento

\footnotetext{
que es aconsejable que lo haga cuando tiene la sospecha de que la empresa cometió una infracción, como se ha dicho.

102 La Orden ministerial que le permitía a la Agencia hacer uso de los enforcement undertakings puede reducir la discrecionalidad administrativa de la misma, en la medida en que puede dejar prefijado el procedimiento a seguir para llegar a esos acuerdos, sus términos y cláusulas, la forma de modificarlo, cuándo se entiende cumplido o no, cómo controlar su cumplimiento, cómo otorgar el certificado de cumplimiento, la forma de apelar la desestimación de la solicitud de la infractora de su otorgamiento, qué hacer cuándo la empresa infractora no da información veraz o completa sobre el cumplimiento del compromiso, la posibilidad de sancionar penalmente a la empresa si sólo ha cumplido parcialmente el compromiso, o la 144 cumple su compromiso (art. 50.5 RESA).
} 
en que se haya emitido, la empresa no podrá ser perseguida penalmente por la infracción cometida o ver cómo se le impone otra sanción administrativa por el mismo hecho (double jeopardy).

La Memoria económica de la RESA prevé que el 10\% de las sanciones administrativas que se hayan de imponer en el futuro sean enforcement undertakings ${ }^{103}$, estimación que está basada en los datos de las sanciones ya impuestas, y un 5\% acaban siendo perseguidas penalmente, ante la renuencia de la empresa por cumplirla.

\section{Ejecución forzosa}

Al igual que ocurría en las demás sanciones de la RESA, el incumplimiento, por parte de la empresa, de las medidas de adopción obligatoria incluidas en el undertaking, permitiría a la Agencia imponer alguna otra sanción para doblegar la voluntad renuente al incumplimiento de la empresa (discretionary requirements, e incluso una fixed monetary penalty, si así estuviera permitido en la Orden ministerial), y si esto tampoco bastara, perseguirla penalmente por la infracción de los dos tipos de infracciones no ejecutadas. Alternativamente también podría la Agencia perseguir penalmente a la empresa por la vía penal desde un principio, por la infracción originaria (art. 50.4 RESA), tal y como hemos comentado que ocurría cuando la empresa incumplía una stop notice.

\section{La recuperación de los costes en los que haya incurrido la Agencia al imponer y ejecutar la sanción administrativa}

La RESA permite a las Agencias recuperar los costes y gastos en que haya poder incurrido al imponer y ejecutar un discretionary requirement o una stop notice ${ }^{104}$. En particular, puede recuperar los costes de investigación e inspección, los costes administrativos o de gestión y las pruebas periciales o informes de especialistas, incluyendo los de la asesoría legal ${ }^{105}$. En este apartado se observa la debilidad y raquitismo de la Administración británica, que carece de un funcionariado suficiente o de un cuerpo de letrados o de asesores legales, razón por la que debe proceder a contratar fuera esos servicios, o a reforzarlos, algo que no ocurre en nuestra Administración. Porque los gastos que las Agencias británicas quieren recuperar de las empresas infractoras son gastos producidos en el procedimiento administrativo, que en España son irrecuperables porque se entienden implícitos en la acción administrativa (salvo aquélla parte que pueda

103 Cfr. BERR (2008), DEPARTMENT FOR BUSINESS ENTERPRISE AND REGULATORY REFORM, Impact Assessment... opus cit.,, p. 32.

104 Por considerar que las fixed monetary penalties y los enforcement undertakings conllevan menos gastos para las Agencias, y habida cuenta también de la aceptación por la Administración de los segundos, los gastos en que éstas hayan podido incurrir al imponer estas sanciones no son recuperables.

105 La RESA permite incluso que los gastos en la realización de la audiencia realizados por el Firsttier Tribunal y por el Upper Tribunal puedan ser recuperados de las partes. 
posteriormente proyectarse en el contencioso-administrativo a modo de costas procesales), parte del servicio público que es la administración pública, en minúsculas.

Para recuperar esos gastos, la Agencia debe notificar a la infractora una notice en la que se contenga la cantidad a pagar, su derecho a requerir a la Agencia un desglose detallado de esa cantidad por conceptos, su derecho a no tener que pagar los gastos que la Agencia hubiese realizado de manera innecesaria, y su derecho a recurrir dicha notice. Para fomentar esa recuperación de costes y la eficiencia, eficacia y racionalidad del procedimiento sancionador, la RESA permite a las Agencias quedarse las cantidades recuperadas, de modo que no están obligadas a confundirlas en el Consolidated Fund, al contrario de lo que ocurre con las sanciones cobradas.

\section{Las guías para el ejercicio de la potestad sancionadora}

Según la RESA, cada Agencia debe publicar, con carácter previo al inicio de su actividad sancionadora, dos tipos de guías (guidance) dirigidas a las empresas y demás administrados. Debe, antes de aprobarlas y revisarlas, otorgar un plazo de información pública a las demás Agencias y a las empresas. Son de dos tipos:

\section{A) Las penalty guidance}

Tienen carácter genérico y propedéutico, y están encargadas de dar a conocer al sector empresarial y de los negocios las nuevas sanciones creadas por la RESA, para que sepan a qué atenerse. En estas guías, las Agencias deben explicar también cómo serán usadas estas sanciones administrativas, en qué circunstancias serán usadas y cuándo no podrán serlo ( $\mathrm{p}$. ej., en caso de fuerza mayor); también podrán incluir la forma de calcular las sanciones económicas y las agravantes y atenuantes de la responsabilidad, recordando también a las empresas de que disponen de un derecho de alegar y objetar contra las sanciones propuestas y, si finalmente no estuvieran de acuerdo con la sanción impuesta, el derecho de recurrirlas ante el Tribunal de primer nivel. Cada Agencia debe someterse a lo que dice en su propia guía, a la hora de ejercer su potestad sancionadora (art. 63 RESA).

\section{B) Las enforcement guidance}

Tienen un carácter más detallado y su finalidad es explicar los modos de sancionar diferentes tipos de infracciones y cómo se ejecutan forzosamente, ex art. 64. En la práctica, como señala el BERR, muchas Agencias se han limitado a incluir las primeras en las segundas ${ }^{106}$. Su contenido fundamental se dedica a exponer a la comunidad

106 BERR (2008), DEPARTMENT FOR BUSINESS ENTERPRISE AND REGULATORY REFORM, Impact

146 Assessment... opus cit., p. 46. 
a la que va dirigida (empresas, empresarios, negocios, comerciantes y demás personas jurídicas prestadoras de servicios o con actividad económica activa) la correspondencia que existe entre cada infracción y su correspondiente sanción, indicando así, por ejemplo, que se preferirá una sanción económica a una medida más gravosa cuando la infracción fuera leve. También debe indicar las formas y acciones que puede emplear la Agencia para ejecutar forzosamente las sanciones impagadas o incumplidas por parte de la infractora (y así, verbigracia, se advertirá que se preferirá la denuncia por la vía penal cuando la infractora tuviese un largo historial de infracciones) (art. 64 RESA) ${ }^{107}$. Este tipo de guías es muy personal de cada Agencia, pues proclama ante los administrados cómo piensa sancionar y ejecutar las infracciones que se produzcan dentro de su actividad administrativa.

Como se ha dicho, la RESA sólo obliga a cada Agencia a publicar sus guías, pero poco dice sobre cómo debe prepararla y escribirla ${ }^{108}$. Según el BERR, cuando las infracciones de una regulación nacional puedan ser sancionadas por Agencias nacionales y Administraciones locales, serán las Agencias nacionales las que elaboren las guías, si bien deberán escuchar previamente en audiencia a las Administraciones locales, la LBRO y al Ministerio del que dependa la Agencia nacional ${ }^{109}$.

Al contrario, cuando sean las Administraciones locales las encargadas de sancionar, como ocurre en materia de salud ambiental, urbanismo o comercio, será la LBRO la encargada de elaborar esas guías, ante la ausencia de Agencias nacionales con competencias al respecto. Habida cuenta de su papel de intermediaria entre la Administración local y el Gobierno estatal, la LBRO está en disposición de elaborar guías únicas para todas las Administraciones locales, dando así la necesaria congruencia y unidad de actuación, si bien escuchando previamente a las partes interesadas, que

107 Puede consultarse el ejemplo del Yorkshire County Council en la web http://www.northyorks. gov.uk/CHttpHandler.ashx?id=81\&p=0, que une ambos tipos de guías en un solo documento. La informalidad de este tipo de guidance les permite especificar todas las formas de sanción de que dispone la Agencia en cuestión, añadiendo a las previstas en la RESA otras establecidas en las leyes especiales recogidas en los Anexos de la misma. Así, en aplicación de la Housing Act 2004, este Council añade entre las sanciones posibles de la RESA dos tipos de cauciones (informal cautions y simple cautions), enforcement orders e incluso la prosecution. Mientras que las cauciones son sanciones para infracciones de poco calado, la vía penal (prosecution) debe usarse "para casos en que existan pruebas suficientes que permitan una sentencia condenatoria, y, además, exista un interés público en hacerlo así”, detallando a continuación las posibles infracciones en las que existe una presunción para poder usar la vía penal (prosecution), lo que claramente está indicando la posibilidad de una sentencia condenatoria, como hemos dicho. Este tipo de presunciones son claramente iuris tantum, pero en nuestro Derecho penal español estarían fuera de toda legalidad porque pugnan abiertamente con la presunción de inocencia, derecho fundamental recogido a nivel constitucional. La única forma de salvar esa contravención, también en el Derecho británico, sería entender que lo que se establece con esas presunciones es una especie de preferencia de la vía penal sobre las infracciones administrativas en esos casos, de manera parecida a como en nuestro Derecho el ámbito objetivo de los tipos infractores administrativos y de los delitos y faltas penales deben diferenciarse siempre, por la gravedad de la ofensa o por las circunstancias distintas que se concitan en el supuesto de hecho.

108 Lo fundamental es que la Agencia debe consultar a las personas afectadas antes de publicarla o antes de modificarlas (arts. 63.2 y 64.4 RESA).

109 BERR (2008), DEPARTMENT FOR BUSINESS ENTERPRISE AND REGULATORY REFORM, Impact Assessment... opus cit., p. 47. 
serán tanto las Administraciones locales como los Ministerios. Esas guías vinculan a la Administración local, de manera que si un Municipio se apartara de ellas a la hora de imponer una sanción podrá ser requerido por la LBRO para cumplirlas.

\section{Requisitos de publicidad de la potestad sancionadora}

El art. 65 de la RESA obliga a las Agencias a publicar por cualquier medio (en esto el Derecho administrativo británico es más informal que el español, que siempre piensa en la publicidad formal de los diarios oficiales) los detalles de las sanciones administrativas impuestas. Aunque se hablar de reports, esto es, informes (que podrían ser anuales, por ejemplo), nada parece impedir que se pueda dar publicidad de las mismas a través de artículos de prensa o incluso en databases en su página web. Esa carga no es obligatoria cuando se trata de sanciones no previstas en el ámbito objetivo de la RESA, y no debe incluir tampoco las sanciones no firmes, que hubieren sido recurridas en tiempo y forma por las empresas sancionadas. La Orden ministerial que atribuye la potestad sancionadora puede incluso eximir a una Agencia de publicar alguna sanción cuando ésta crea que su publicación no es apropiada, para proteger datos personales o privados de la empresa o en otros casos similares.

\section{Medidas adicionales y suplementarias a la sanción administrativa}

Al igual que en nuestro Derecho Administrativo sancionador la sanción puede incluir pronunciamientos accesorios a la propia sanción, tales como la obligación de recuperar el entorno dañado o de indemnizar los daños producidos (art. 130.2 LRJAPyPAC), también la RESA permite que las Órdenes ministeriales que atribuyan potestad sancionadora a las Agencias puedan incluir provisiones distintas a las previstas en la misma, con una finalidad complementaria no punitiva, sino para que sean usadas por éstas como mecanismo facilitador de la potestad sancionadora. Así, la Orden podrá incluir provisiones "adicionales" (consequential provisions) sobre cómo podrán las leyes previas a la RESA ser ejecutadas por las Agencias mediante los instrumentos en ella previstos, y sobre cómo esas leyes pueden o no tipificar delitos por el incumplimiento de las obligaciones que imponen a los administrados, si previamente ya se impuso, con base en la RESA, una de sus sanciones administrativas.

Con sus "medidas suplementarias", las Órdenes ministeriales deben facilitar a las Agencias la imposición de las sanciones administrativas previstas en la RESA, atribuyéndoles potestad para solicitar información, otorgarles derecho a entrar en sus sedes, inspeccionarlas, y a usar las pruebas admitidas contra las empresas en la vía penal para imponerles una sanción administrativa. La prueba penal vincula a la realizada en el procedimiento administrativo, como prueba tasada que es, lo que no ocurre al contrario ${ }^{110}$.

110 En nuestro Derecho sancionador las pruebas realizadas en el procedimiento administrativo sancionador no vinculan a los jueces de lo contencioso-administrativo, ni tampoco a los jueces penales. Por la 
El otorgamiento de estas potestades suplementarias, permitidas por el art. 55 de la RESA, a veces pueden necesitar la modificación o derogación de una Ley (apdo. $\left.4 .^{\circ}\right)$, que sea contraria al ejercicio de esas provisiones.

\section{EL NUEVO CONTROL JUDICIAL DE LA POTESTAD SANCIONADORA EN EL REINO UNIDO}

\section{La creación de una suerte de jurisdicción contencioso-administrativa material británica: el Firt-tier Tribunal, el Upper Tribunal y la Supreme Court}

\section{A) Su organización}

Como ha dijimos arriba, el Tribunal de primer nivel, o de primera instancia (Firsttier Tribuna) ha sido creado por la TCEA como una especie de nuevo Tribunal contencioso-administrativo con competencia universal o general en el Reino Unido, para resolver los recursos interpuestos por los administrados contra determinadas decisiones del Gobierno y sus agentes, y, en particular, contra las sanciones impuestas sobre la base de la RESA. La TCEA creó también un Upper Tribunal (o Tribunal de segunda instancia, o superior), para resolver las apelaciones contra las decisiones del First-tier Tribuna ${ }^{111}$, apelaciones que, antes de la erección de estos dos Tribunales administrativos, eran resueltas por la High Court.

La creación de estos Tribunales supone una especialización judicial en asuntos de la Administración, pero, no obstante, formalmente, ambos Tribunales se incardinan dentro de los Tribunales civiles (la que se encargan también de enjuiciar a la Administración, que es un sujeto más equiparable a cualquier ciudadano), sin que en su creación se haya hecho afirmación alguna acerca de la formalización de una tercera jurisdicción en el Reino Unido, parecida a nuestra jurisdicción contencioso-administrativa, que se venga a sumar a la civil y a la penal. La novedad se produce, pues, en relación con su objeto, no en relación con la organización judicial, es más material que formal.

La finalidad de estos dos nuevos Tribunales es la de centralizar en ambos las competencias de control que, sobre las decisiones ministeriales y de sus Agencias, tienen los muchos tribunales creados por los distintos Ministerios. Esas competencias se irán

\footnotetext{
misma razón de independencia, creemos que este extremo sería plenamente aplicable a lo que se acaba de decir, ya que los jueces penales siempre podrán exigir la práctica de nuevas pruebas o incluso valorar de manera distinta las que se hubieran realizado durante el procedimiento sancionador conforme a la RESA.

111 La Parte I de la Tribunals Courts and Enforcement Act 2007 tiene la misión de integrar, simplificar y concentrar todas las funciones administrativas y judiciales de los Tribunales, para lo que se creó también el Tribunal Service, como organismo gubernamental encargado de esta labor, que se resume, fundamentalmente, en separar a cada Ministerio de sus respectivos Tribunales, antes unidos, y en reunirlos en un sistema más sencillo. En apoyo del Tribunal Service, el Tribunal Procedure Committee está encargado de la elaboración de las reglas procesales de cada jurisdicción.
} 
transfiriendo progresivamente a estos dos nuevos Tribunales, de forma que a medio plazo conformen una especie de jurisdicción contencioso-administrativa general.

El Tribunal de primer nivel es una especie de Tribunal de primer instancia (ya que caben apelaciones ante el Tribunal Superior, o Upper Tribunal), tiene jurisdicción nacional y está dividido en cuatro Cámaras: la Social Entitlement Chamber, la Health, Education and Social Care Chamber, la the War Pensions and Armed Forces Compensation Chamber y la Tax Chamber ${ }^{12}$. En 2008, aprobada por el Parlamento, fue creada ${ }^{113}$ una nueva Cámara, denominada General Regulatory Chamber (GRC), que comenzará ha comenzado a funcionar en septiembre de 2009, una especie de jurisdicción contencioso-administrativa genérica (ya que las otras cuatro Cámaras del Firts-tier Tribunal resuelve asuntos contencioso-administrativos específicos), que se encargará de resolver los recursos contencioso-administrativos contra las sanciones que actualmente resuelven otros Tribunales administrativos ${ }^{114}$, esto es, Tribunales individuales que funcionan en paralelo al Firts-tier Tribunal y que pueden tener la jurisdicción que le otorguen las leyes que los creen.

La TCEA les atribuye también a los dos nuevos Tribunales la facultad de ejecutar sus sentencias por sí mismos, sobre todo cuando tienen contenido económico. Así, si por ejemplo una sanción no fuera pagada por el administrado y fuera sentenciado a hacerlo, el art. 27 TCEA le permite a los Tribunales hacerlo por sí mismos, como si fuera un auto o sentencia de los Tribunales civiles (civil courts), sin necesidad, por tanto, de tener que pedirlo a los county tribunals o a la High Court ${ }^{115}$.

La GRC, que contará con un Presidente, reunirá a todos los Tribunales que hasta ahora se encargaban de esa función, y lo hará en dos fases: en septiembre de 2009 han sido abolidos, y se integrarán en la misma, los Tribunales de Caridad (Charity), de créditos de consumidores (Consumir Credit Appeals), sobre la propiedad inmobiliaria (State Agents Pane), y algunas funciones de los Tribunales de Transporte sobre licencias de conducir. Más tarde, en enero de 2010, está previsto que sean abolidos, y se integren en la General Regulatory Chamber del Tribunal de Primer nivel los Tribunales de inmigración (Inmigration Services) y los de Suspensión de pagos y Bancarrotas ( $A d$ judication Panel for England), de Información, juegos y apuestas (Gambling Appeals) y

112 Las competencias de cada Cámara pueden consultarse en la Orden 2684/2008: The First-tier Tribunal and Upper Tribunal (Chambers) Order 2008. Inicialmente las Cámaras que componían el First-tier Tribunal eran sólo las tres primeras. La Tax Chamber fue creada posteriormente, por la Orden 196/2009, titulada: First-tier Tribunal and Upper Tribunal (Chambers) (Amendment) Order 2009.

113 En la Orden titulada: "General Regulatory Chamber by the First-tier Tribunal and Upper Tribunal (Chambers) Order 2008(a)".

114 Vid. Documento general sobre el proyecto de Orden que recoge el proceso ante la GRC: Tribunal Procedure (First Tier Tribunal) General Regulatory Chamber Rules 2009.

115 También podría la misma Administración solicitar una Administration orders de las previstas en la Parte $V$ de la TCEA para ejecutar las deudas de sus administrados, a través de un procedimiento ejecutivo que puede adoptar incluso, como medidas de ejecución, la interrupción del suminisrto de electricidad o/y

150 gas (art. 112l). 
de reclamaciones de daños y perjuicios (Claims Management) ${ }^{116}$. Para cada transferencia de jurisdicción entre un Tribunal actual y los dos nuevos Tribunales creados por la TCEA será necesaria la aprobación del Parlamento.

Todos los jueces de los Tribunales abolidos y por abolir pasarán al Tribunal de primer nivel, y cada caso será oído por Secciones, que englobarán a, como mínimo, tres jueces especializados en materia administrativa. En el momento de escribir este estudio se está realizando un borrador de las reglas de procedimiento de la General Regulatory Chamber, que ya han sido sometidas a información pública ${ }^{117}$. Algún Tribunal no quedará abolido, pero será una excepción ${ }^{118}$.

Las sentencias de la General Regulatory Chamber del Tribunal de primer nivel pueden ser variadas, siempre que la orden ministerial así lo permita: anular la sanción, confirmarla, aconsejar a la Agencia que la sustituya por otra sanción más razonable, e incluso devolver la decisión a la Agencia para que la reconsidere o matice. El recurso tendrá efecto suspensivo de las sanciones impuestas sólo cuando así lo haya previsto la orden ministerial (art. 54.3, a RESA).

El Upper Tribunal también está dividido en Cámaras: la Administrative Appeals Chamber, la Finance and Tax Chamber y la Lands Chamber. La primera de ellas resuelve las apelaciones interpuestas contra las sentencias dictadas por la GRC.

Los recursos frente a las resoluciones de los Tribunales establecidos en la RESA también serán resueltas por el Tribunal de primer nivel (ante la GRC) y, posteriormente, en su caso, en apelación ante el Upper Tribunal.

Los plazos para plantear las apelaciones ante el Upper Tribunal quedarán establecidos en las reglas de procedimiento que en estos momentos se están redactando para la General Regulatory Chamber del Tribunal de primer nivel, aunque se prevén que varíen en relación con el tipo de sanción impuesta, la Agencia implicada y la infracción cometida: así, por ejemplo, el plazo para recurrir una stop notice será más breve que el de cualquier otra sanción, por razones obvias de urgencia y de posible afectación al interés público.

Todo el sistema judicial contencioso-administrativo en el Reino Unido (administrative justice system) está controlado por el Administrative Justice and Tribunals

116 Para más tarde quedan las transferencias de otros Tribunales administrativos, como: el Sea Fish License Tribunal, el Aircraft \& Shipping Tribunal, el Antarctic Act Tribunal, el NHS Medicines Appeal Tribunal, el Plant Varieties and Seeds Tribunal, el Insolvency Practitioners Tribunal, el Foreign Compensation Commission, el Chemical Weapons Licensing Appeal Tribunal y el Mines and Quarries Tribunal.

117 Ese borrador, titulado "The Tribunal Procedure (First-tier Tribunal) (General Regulatory Chamber) Rules 2009" puede consultarse en el Anexo A del siguiente documento: http://www.tribunals.gov.uk/ Tribunals/Documents/Grc/GRConsultationPaper.pdf

118 Es lo que ocurre con los Tribunales laborales (employment tribunals), que no forman parte del Tribunal de primer nivel, y que se encarga de resolver las apelaciones contra sanciones que afecten al ámbito laboral (salud laboral, riesgos en el trabajo, etc.). 
Council (AJTC, una especie de CGPJ, pero dedicado exclusivamente a la jurisdicción contencioso-administrativa británica), que es un organismo independiente, no gubernamental, con carácter asesor, regulado en los arts. 44 y ss. y en el Anexo $7 .^{\circ}$ de la TCEA, que reemplaza al hasta entonces denominado Council of Tribunals. El AJTC está compuesto por el Comisionado Parlamentario para las Administraciones y por un grupo de entre 10 y 15 miembros nombrados por las autoridades británicas, escocesas y galesas; el Lord Chancellor nombra a su presidente, con un mandato de cuatro años, actualmente el Sr. Richard Thomas.

Las funciones principales del AJTC son las de vigilar el correcto funcionamiento de la justicia contencioso-administrativa en el Reino Unido y establecer mecanismos para hacerla accesible, justa y eficiente ${ }^{119}$. Para ello emite informes sobre normas administrativas o sobre la posible reforma de las reglas procesales; sobre las normas procesales de la justicia contencioso-administrativa, previos a su aprobación por los Ministros competentes (sobre todo en relación con el First-Tier Tribunal y el Upper Tribuna); o redacta comentarios a la legislación administrativa relacionada con los tribunales contencioso-administrativos ${ }^{120}$. Los Tribunales supervisados por el AJTC pueden consultarse en los Informes anuales de la AJTC ${ }^{121}$.

Tras la aprobación de la Constitutional Reform Act de 2005 se ha instituido en el Reino Unido un Tribunal Supremo (denominado Supreme Court of the UK), que está llamado a ser la última instancia judicial del reino, en todas las jurisdicciones. Viene a reemplazar a la Sección judicial de la Cámara de los Lores (Law Lords o Appellate Committee of the House of Lords), si bien, como gesto histórico de sucesión, la Ley consa-

119 Ello incluye vigilar los plazos de resolución de los pleitos, evitando retrasos injustificados. Como se ve, actúa en el sistema judicial contencioso-administrativo británico de modo parecido a como lo hace el CGPJ con todo el sistema judicial en España, ya que también tiene funciones de control sobre el personal y sobre su dotación económica y material (esta última función transferida ya a varias CC.AA. en nuestro país). Sin embargo, una de sus diferencias fundamentales es que el propio AJTC ha creado un sistema de resolución extrajudicial de pleitos contenciosos, que incluso se fomenta, denominado Proportionate Dispute Resolution, de forma parecida a lo que ocurre ya desde hace tiempo en EE.UU. con su Alternative Dispute Resolution, sobre la que tuvimos ocasión de pronunciarnos en su momento. Cfr. Sánchez Sáez, A. J. (2003): "Reflexiones sobre la Resolución Alternativa de Conflictos administrativos en los Estados Unidos de América: su virtualidad en el Derecho Ambiental”, en la obra colectiva, coordinada por Carmen Carretero Espinosa de los Monteros, Alternativas no jurisdiccionales en la Resolución de Pretensiones de Derecho Público, VI Jornadas de Estudio del Gabinete Jurídico de la Junta de Andalucía, IAAP-Consejería de Justicia y Administración Pública-Consejería de la Presidencia, Sevilla, p. 317 y ss.

120 También el Lord Chancellor, actualmente el Sr. Jack Straw, tiene el deber general (general duty) de asegurar la eficiencia y efectividad del sistema de tribunales contencioso-administrativos (el First-tier Tribunal, el Upper Tribunal, los employment tribunals, el Employment Appeal Tribunal y el Asylum and Inmigration Tribunaf), ex art. 39 TCEA.

121 Vid. ADMINISTRATIVE JUSTICE AND TRIBUNALS COUNCIL, Annual Report 2007/2008, p. 56 y ss. Aparte del First-tier Tribunal y del Upper Tribunal, el AJTC controla y supervisa una serie de Tribunales sectoriales de distintos sectores normativos, todos ellos encargados de revisar las resoluciones administrativas dictadas al amparo de esas normas. Así, los Tribunales de asilo e inmigración, los Tribunales de educación, de empleo, de finanzas e ingresos, de salud, de información y de protección de datos, de propiedad intelectual, de propiedad inmobiliaria, de seguridad social y pensiones, tráfico y transportes, urbanísticos, etc. 
gra que sean los actuales doce Lores de la sección judicial los que sean titulares del primer mandato del Tribunal Supremo ${ }^{122}$.

\section{B) Los recursos judiciales frente las sanciones administrativas}

\section{Frente a las "fixed monetary penalties" y los "discretionary requirements"}

Cuando la empresa a la que se le ha impuesto una sanción administrativa considere que ha mediado error de hecho, invalidez jurídica, o irrazonabilidad en la cuantía-profundidad de la sanción, tiene derecho a recurrir ante el Tribunal de primer nivel. Los motivos para recurrir deben haber sido explicitados en la Orden ministerial.

El $15 \%$ de las fixed monetary penalties impuestas ha sido recurrido hasta el momento ${ }^{123}$.

El 30\% de los discretionary requirements impuestos ha sido recurrido, un porcentaje mayor que el las fixed monetary requirements, debido, tal vez, a la mayor onerosidad que aquéllos suponen para las empresas sancionadas, en relación a éstos ${ }^{124}$. La Memoria económica de la RESA prevé que el $20 \%$ de las sanciones administrativas que se han de imponer en el futuro sean variable monetary penalties ${ }^{125}$, estimación que está basada en los datos de las sanciones ya impuestas.

\section{Frente a las "stop notices"}

Si la empresa no estuviera de acuerdo con la stop notice recibida o con la denegación de emisión de un certificado de cumplimiento, como en todas las demás sanciones administrativas, esa empresa puede recurririr26 esas decisiones, sobre la base

122 La Supreme Court está regulada en la Parte Tercera de la Constitutional Reform Act de 2005. Se prevé que eche a andar a primeros de octubre de 2009, una vez que sea completamente restaurado el edificio Middlesex Guidhall, que conforma una de las esquinas del conjunto de las casas del Parlamento británico, aunque separado del Parlamento (lo que es bastante revelador de hasta qué punto se quiere empezar a separar el Poder legislativo del judicial, hasta ahora unidos en la Cámara de los Lores). Cada vacante producida en las doce plazas de jueces del Tribunal Supremo será cubiertas mediante la designación de nuevos jueces, encargo que se le hace a una nueva comisión judicial (Judicial Apponintments Commission) de carácter político y técnico. Se encargará también de dilucidar los pleitos que surjan en relación con la distribución de competencias entre Inglaterra y las demás naciones británicas (Gales, Irlanda del Norte y Escocia), en las materias transferidas (devolved matters). Será la última instancia de apelación de las jurisdicciones civil y penal en el Reino Unido (los asuntos contencioso-administrativos se integran en la jurisdicción civil).

123 Cfr. BERR (2008), DEPARTMENT FOR BUSINESS ENTERPRISE AND REGULATORY REFORM, $/ \mathrm{m}$ pact Assessment... opus cit., mayo de 2008, p. 33.

124 Cfr. BERR (2008), DEPARTMENT FOR BUSINESS ENTERPRISE AND REGULATORY REFORM, Impact Assessment... opus cit., mayo de 2008, p. 34.

125 Cfr. BERR (2008), DEPARTMENT FOR BUSINESS ENTERPRISE AND REGULATORY REFORM, Impact Assessment... opus cit., mayo de 2008, p. 32.

126 El 20\% de las stop notices impuestas ha sido apelado. Cfr. BERR (2008), DEPARTMENT FOR BUSINESS ENTERPRISE AND REGULATORY REFORM, Impact Assessment... opus cit., mayo de 2008, p. 35. 
del error de hecho, de la invalidez jurídica de ese acto administrativo (to be wrong in law), de la irrazonabilidad de la decisión de imponer la sanción o de cualquiera de las obligaciones que suponía la aplicación de la misma, o alegando que no había cometido la infracción en ningún caso, o que no era responsable (liable) de haberla cometido, y que, por tanto, no habría sido declarada culpable penalmente (convicted) en el caso en que se hubiera tramitado la infracción por la vía penal, por haber acaecido una circunstancia que conjuraba esa responsabilidad (haber seguido órdenes administrativas, fuerza mayor, etc.). Los motivos aducidos para fundamentar este recurso deben encontrarse determinados en la Orden ministerial, que incluso debe indicar expresamente si dicho recurso tiene o no efectos suspensivos sobre la sanción (en este caso, la stop notice) o sobre la desestimación del certificado de cumplimiento. (art. 47 RESA).

\section{Frente a los "enforcement undertakings"}

En cuanto a la posibilidad de recurrir la ejecución del acuerdo, no parece que sea una situación muy usual, habida cuenta de que la principal virtud y razón de ser de este tipo de acuerdos es la aceptación de la empresa a las medidas en él incluidas. De todas formas, en puridad, la Agencia podría abusar del acuerdo e imponer alguna medida ultra vires, no incluida en su ámbito objetivo, en cuyo caso, siempre que la Orden ministerial lo permitiera, sería posible el recurso. También podría recurrirse la denegación de un certificado de cumplimiento de las medidas adoptadas por la empresa.

\section{Las garantías y derechos del art. 6 CEDH (y de la Human Rights Act 1998) aplicables al procedimiento administrativo sancionador y a los procesos judiciales frente a sanciones administrativas en el Reino Unido}

Como se dijo antes, el art. $6 \mathrm{CEDH}$, en sus apartados $2 .^{\circ}$ y $3 .^{\circ}$ prevé una serie de garantías y derechos procesales para los reos de juicios penales. No obstante, la jurisprudencia del TEDH y la de los países que lo suscribieron (entre ellos España y Reino Unido) han acabado exigiendo el respeto de los mismos también cuando se trata de sanciones o multas equiparables por su gravedad a los delitos y faltas. Entre ellas están las sanciones administrativas (en España) y algunas sanctions y penalties en el Reino Unido. El impacto que el nuevo Derecho Administrativo, como garante de los derechos de los administrados frente a la intervención de los poderes públicos, está teniendo en el Derecho británico no siempre es seguido entusiásticamente por la propia doctrina $^{127}$.

127 Así, Poole, T (2007), “The reformation of English Administrative Law”, en Law Society Economy Working Papers, 12/2007, Londres, considera queue la excesiva preocupación de las Agencias por los dere-

154 chos de los administrados puede acabar minando la eficacia de la actuación administrativa. A favor del 
Así, por ejemplo, ocurre que en el Reino Unido son equiparables a los delitos las sanciones militares de carácter disciplinario, o las peticiones de cárcel por desacato a un Tribunal (contempt of court). La propia jurisprudencia del TEDH ha equiparado determinadas sanciones a los delitos, a los efectos de la aplicación de los derechos del art. $6 \mathrm{CEDH}$, independientemente de que esas sanciones sean consideradas civiles y no criminales por el Derecho británico. Así, en Han and Yau, Martins and Martins, Morris v Customs and Excise Commissioners [2001] 1 WLR 2253- el TEDH sentenció a favor de la aplicación del art. 6 a las sanciones impuestas por evasión fiscal; en International Transport Roth Gmbh and Others $v$ Secretary of State for the Home Department [2002] 3 WLR 344 - el TEDH estimó la aplicación del art. 6 a las sanciones impuestas a conductores de camiones que transportaban a introducían clandestinamente a inmigrantes en UK; en McCann v UK [1996] 21 EHRR 97 - el TEDH excluyó la aplicación del art. 6 a las órdenes dictadas por conductas antisociales (vandalismo, ruidos entre vecinos, etc.); en McIntosh v HM Advocate, HM AdvocateGeneral for Scotland) [2001] 3 WLR 107 and $R v$ Benjafield [2003] QB 728 - el TEDH sentenció la no aplicación del art. 6 a las órdenes de confiscación de los fardos o alijos de drogas aprehendidos por la policía; en Gough and others v Chief Constable of Derbyshire and others [2002] 3 WLR 289 - el TEDH consideró que las órdenes de prohibición en materia de fútbol internacional no eran equiparables a sanciones penales, si bien la fase de prueba debía respetar el art. 6 CEDH; y en $R$ (Mudie) v Dover Magistrates' Court [2003] 2 WLR 1344 - el TEDH sentenció que no se aplicaba el art. 6 a los procedimientos iniciados para confiscar bienes, según el art. 139 de la Customs and Excise Management Act 1979; tampoco a la retirada de los permisos carcelarios se aplica el art. 6 CEDH ( $R$ (West) v Parole Board (2003) 1 WLR 705); sí se le aplican determinados derechos del art. 6 a los presos que ya hubiesen cumplido un período mínimo de cárcel (Williams v Secretary of State for the Home Department (2002) 1 WLR 2264).

En esta inteligencia, el art. 6.1 de la Human Rights Act de 1998 considera que es "ilegal para una autoridad pública actuar de forma incompatible con un derecho del CEDH", y esos derechos son exigibles, conforme mandata su art. 6.3, tanto a los Tribunales (courts o tribunals) como a las Administraciones ("any person certain of whose functions are functions of a public nature"). Por tanto, esos derechos, en la medida en que así haya sido considerado por la propia jurisprudencia del TEDH, serán aplicables tanto a los procedimientos administrativos sancionadores como a los juicios ante tribunals (especie de vía administrativa previa a la jurisdicción civil, que en el Reino Unido se ocupa también, como se ha dicho, de la revisión de los actos administrativos) o Tribunales (courts). Eso sí, en la definición de autoridad pública no se incluye al Parlamento, con lo que se salvaguarda su soberanía frente al CEDH.

\footnotetext{
a raíz de la Human Rights Act 1998 se muestra OF LAIRGH, LORD IRVINE (2003), Human Rights, Constitutional Law, and the development of the english legal system, Hart Publishing, Portland, Oregon, pp. 111 y ss., en un interesante análisis interno, como Lord integrante de la Cámara de los Lores, del proceso de redacción y aprobación de la Ley, y de su impacto beneficioso en el Derecho británico. En su opinión, al rule of law debe adherirse necesariamente la protección y la garantía de los derechos de los administrados, sin que ello suponga politizar la justicia, ni dar un papel más relevante a los abogados en la tramitación de los procesos.
} 
Normalmente el plazo para la revisión judicial antes los tribunals y courts británicos de las sanciones que hubiesen incurrido en violación de los derechos del Convenio es de un año (art. 7.5), salvo que una court (Tribunal), a la vista de las circunstancias del caso, considerase que se puede ampliar. Mediante Orden ministerial se puede intitular a los tribunals para que adopten determinados remedios (remedies) con los que paliar la vio-

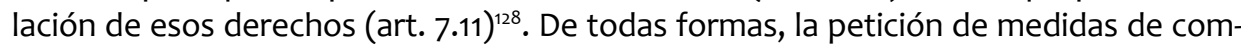
pensación económica sólo puede sustanciarse ante los tribunales civiles (art. 8.2).

En general, los apdos. $2 .^{\circ}$ y $3 .^{\circ}$ del art. 6 CEDH se aplican a los procedimientos sancionadores de las Administraciones públicas, aunque no con la misma profundidad y extensión como pudiera hacerse en un juicio por lo penal. Por el contrario, serán aplicables a ese nivel cuando la sanción se recurra ante los Tribunales (las civil sanctions se ventilan y resuelven por los civil courts, aunque puedan tener una especialización administrativa, nunca por los criminal courts). Así, conforme a la interpretación que da del art. 6 CEDH el Ministerio de Asuntos constitucionales, justicia, derechos y democracia ${ }^{129}$, en los juicios contra las sanciones administrativas deben respetarse los siguientes derechos y garantías, algunas de las cuales también son extensibles al procedimiento administrativo sancionador previo:

- el sancionado tiene derecho a una motivación plena de las razones que han llevado a la Administración a la imposición de la sanción; se trata de una garantía que, obviamente, también se aplica a los procedimientos administrativos sancionadores; sin embargo, en la vía administrativa no se garantiza la asistencia jurídica gratuita, como ocurre ante los Tribunales (algo que tampoco ocurre en nuestro país), aunque puede resultar matizable ${ }^{130}$;

128 Los remedies son mecanismos de revisión judicial propios del Common Law, que configuran procesos determinados para detener o revisar actuaciones de cualquier sujeto (y, por tanto, también decisiones administrativas). Son los siguientes, dictados por los jueces y Tribunales:

- certiorari, que es una orden dirigida a la Administración o a un Tribunal para que justifique una decisión ya adoptada;

- mandamus, una orden por la que se compele a una persona o Administración para que cese en su inactividad y lleve a cabo un deber establecido por la Ley (se parece a nuestro art. 29 LJCA);

- prohibition, que es una orden por la que se previene o prohíbe a una Administración que actúe en exceso de poder (ultra vires);

- quo warranto, una orden por la que se exhorta a un individuo o Administración a que ejerza sus potestades para poder justificar su jurisdicción;

- habeas corpus, que es una orden en la que se requiere a una Administración o individuo para que justifique la detención de una persona, o, caso contrario, la ponga en libertad;

- injunction, adopción de medidas cautelares por el juez antes de que adquieran efecto las decisiones administrativas, y la

- declaration, que es un juicio declarativo en el que el juez declara la realidad jurídica de una actuación administrativa, diciendo si se ajusta a derecho o no, por entrar en colisión con derechos de los particulares.

Cfr. Fitz Gerald, R. (2005), Administrative Justice and Inter-Ministerial Communication Within Public Administration, Trieste, marzo 2005, p. 19 y Bailey, S. H., Jones B. L., y Mowbray, A. R. (1992), Cases and opus cit., pp. 774-791.

129 Vid. DEPARTMENT OF CONSTITUCIONAL AFFAIRS, JUSTICE, RIGHTS AND DEMOCRACY (2006), A Guide to the Human Rights Act 1998, Third Edition, octubre de 2006, pp. 18-20.

130 EI TEDH en algunas ocasiones ha entendido que, aunque se trate de sanciones, si la complejidad del asunto es grande o si existe obligación de que exista representación legal, la asistencia jurídica gratuita 
- el acusado tiene el derecho a defenderse (fair hearing) y de prueba, en unas condiciones tales que no supongan una desventaja sustancial con la otra parte, en este caso la Administración: por esa razón puede incluso recibir ayuda y asistencia de la misma para practicar la prueba; debe tener acceso también al expediente elaborado por la Administración y el derecho de preguntar a los testigos presentados por la misma. También los testigos y víctimas de las infracciones están protegidos conforme al art. $6 \mathrm{CEDH}$ : si son jóvenes o vulnerables la Administración debe protegerles, de forma que el acusado no puede repreguntar a un testigo que alegue haber sido víctima de la sanción cometida; estas garantías también se aplicas a los procedimientos administrativos sancionadores;

- al acusado debe tener el derecho de defensa en público, de manera que el público en general y que la prensa pueda acceder a la sala, salvo casos en los que se ventilen asuntos en que se pueda afectar a la intimidad o la moral del acusado o de sus víctimas, o en que existan razones de interés público o de seguridad nacional, o haya que proteger a menores de 18 años; también tienen derecho a audiencias públicas los sancionados en procedimientos administrativos cuando existan importantes divergencias en los hechos y las pruebas aportadas por las partes ${ }^{131}$.

- el derecho a un juez imparcial e independiente se provee evitando que en los sistemas de designación del mismo haya habido alguna influencia de la Administración que sancionó; y evitando que ese juez estuviera incurso en causas de abstención, que en el Reino Unido no son tan exigentes como en nuestro derecho, siendo más prácticas: por ejemplo, no siempre que el juez asesoró a la Administración en un asunto previo incurre en causa de abstención, sino sólo en aquéllos casos en que la asesoría versaba con el mismo tipo de caso que después iba a sentenciar. En todo caso, debe protegerse la apariencia de independencia, aplicándose el principio de in dubio pro reo. Esta garantía no es aplicable a los procedimientos administrativos sancionadores ${ }^{132}$;

- el derecho a un juicio sin dilaciones indebidas se aplica tanto a los juicios ante los civil tribunals frente a las sanciones como también, mutatis mutandi, al mismo procedimiento administrativo de imposición previo. En la vía judicial, eso dependerá de diversas circunstancias, como la complejidad del caso, la diligencia de ambas partes en el juicio o la propia diligencia del Tribunal, de modo que la inadecuación de los

debe darse para dar por protegidos los derechos del art. 6 CEDH. Así ha ocurrido con los procesos de adopción o de guarda y tutela de menores por parte de sus padres ( $P, C$ and $S$ v UK [2002] 32 EHRR 31).

131 Véanse las SSTEDH Adnan v Newham LBC [2002] 1 WLR 2120, y Begum v Tower Hamlets $L B C$ [2003] 2 AC 430.

132 Ya que es normal que el funcionario o empleado público que tramita o impone la sanción tenga una relación contractual con la Administración, sin que ello, conforme a la Human Rights Act de 1998, constituya una presunción de parcialidad contra ese empleado, y además, siempre cabría una revisión judicial posterior del asunto, que conjura las posibles desviaciones (bias) del mismo. Así quedó sentenciado en el caso Alconbury ( $R$ (Alconbury Developments $L t d)$ v Secretary of State for the Environment, Transport and the Regions [2001] 2 WLR 1389), en materia de urbanismo y propiedad privada, en la que el TEDH sentenció que las decisiones tomadas por el Ministro eran legítimas, y que el hecho de que ese tipo de decisiones no las tome un Tribunal no vulnera el art. $6 \mathrm{CEDH}$. 
recursos de los Tribunales no debe ser excusa para el retraso (aquí la expresión inadecuacy no se refiere a retrasos motivados por problemas estructurales de falta de medios o de recursos técnicos o económicos, sino a lo que la jurisprudencia británica denomina maladministration, es decir, un mal uso objetivo de esos recursos, o negligencia en quienes tienen que impulsar el proceso, jueces, funcionarios o peritos) $)^{133}$; no existe tal derecho en la vía administrativa;

- el derecho a permanecer en el juicio durante el proceso, de modo que la ausencia deliberada del acusado no entraña una vulneración del art. 6 CEDH;

- el derecho del acusado a no decir nada que pueda incriminar al acusado, o “derecho al silencio"; es aplicable al procedimiento administrativo sancionador;

- el derecho a la presunción de inocencia, de modo que la carga de la prueba debe recaer en la Administración; es aplicable al procedimiento administrativo sancionador;

- el derecho a ser informado prontamente de la acusación en un idioma que el acusado entienda; es aplicable al procedimiento administrativo sancionador;

- el derecho a que la Administración que impuso la sanción o que la Administración de justicia adecue sus tiempos e instalaciones para facilitar la defensa del acusado;

- el derecho a que el acusado se defienda a sí mismo; también es aplicable, evidentemente, al propio acusado en el procedimiento administrativo sancionador;

- el derecho a un intérprete durante todo el proceso o, en su caso, durante todo el procedimiento administrativo sancionador;

- el derecho a ser informado de las pruebas que maneje la Administración, tanto en el procedimiento administrativo sancionador como en el juicio posterior, en su caso; lo mismo debe ocurrir cuando las pruebas fueron conseguidas por informadores de la policía o mediando provocación (entrapment) ${ }^{134}$;

- no siempre la violación del art. 8 acarrea la violación del art. 6 cuando las pruebas se han obtenido mediante pinchado de líneas telefónicas (en casos en que se autorizaran esas escuchas).

133 Un retraso injustificado de más de 20 meses durante el proceso suele ser declarado inaceptable. Véanse los casos Re D (A Child) [2002] 2 All ER 668, HM Advocate v JK [2002] HRLR 21 o Procurator Fiscal $v$ Watson and Burrows [2002] HRLR 21.

134 Vid. McNally v Chief Constable of the Greater Manchester Police, R v Loosely [2001] 1 WLR 2060, Edwards and Lewis $v$ UK ECtHR, 22 July 2003. En estos casos el TEDH acabó concluyendo que el acusado 158 tenía derecho a saber la identido motivos de seguridad. 


\section{LA BÚSQUEDA DE LA INTERVENCIÓN ADMINISTRATIVA MÍNIMA: LA PARTE CUARTA DE LA RESA (REGULATORY BURDENS)}

\section{Concepto de burdens}

La Parte Cuarta de la RESA, como se dijo en la parte introductoria de nuestro comentario a la RESA, parte de una visión muy anglosajona de la regulación administrativa, que arrastra un prejuicio ancestral contra las restricciones de libertades, y esa es la razón por la que la se pretende reducir las cargas (burdens) impuestas por las Administraciones a los administrados y, en particular, a las empresas y demás agentes económicos, cuando limiten innecesariamente su libertad de acción, su libertad de empresa. Se trata de una actuación que se engloba dentro de una política pública general dirigida a mejorar la regulación y actividad administrativa (Better regulation). La RESA obliga así a las Agencias a replantearse su regulatory function, empleándola solamente para imponer gravámenes administrativos a las empresas y demás personas jurídicas privadas sólo cuando sean necesarias, y siempre de forma proporcionada y práctica. Se aconseja también una revisión de la normativa ya aprobada para eliminar esos gravámenes innecesarios ya existentes. Esta Parte IV de la RESA, por tanto, afecta, y mucho, a las líneas básicas del ejercicio de la potestad sancionadora, como potestad de gravamen que es, tal vez la más importante.

La intención de esta reducción de las cargas administrativas, eje común del Programa “Better Regulation", como se dijo en la Introducción de este estudio, es aligerar a las empresas de los costes y cargas administrativas redundantes, algo muy caro al liberalismo anglosajón, aparentemente en contradicción con los controles y garantías de las actividades de policía à la française, aunque, finalmente, a la vista de su ascendencia en el mundo empresarial y de los negocios, se ha acabado imponiendo como una política común en la UE (Plan de Lisboa 2001,o Estrategia Renovada de Lisboa, y, dentro de ella, el Programa de Acción de la Comisión Europea de Reducción de Cargas Administrativas), y, por tanto, también en nuestro país ${ }^{135}$.

135 “El Plan de Reducción de Cargas Administrativas y la Mejora Regulatoria” fue aprobado por el Consejo de Ministros el 20 de junio de 2008, y tiene dos objetivos fundamentales: eliminar de la normativa vigente los trámites administrativos redundantes, obsoletos, reiterativos e innecesarios; y actuar preventivamente sobre la normativa futura, de tal suerte que no contenga nuevas obligaciones administrativas para ciudadanos y empresas. Los beneficiarios de este Plan son los ciudadanos y empresas en sus relaciones con la Administración, por la reducción del coste de realización de los trámites en términos de menores requisitos, la posibilidad de realizar muchos de ellos sin necesidad de acudir a una oficina de la administración, o por la supresión del trámite cuando éste es injustificado. Según cálculos de la Comisión Europea, la aplicación rigurosa de este Plan podría traducirse en un crecimiento adicional del 1,5\% en el nivel de PIB de la economía española. En la web del Ministerio de Política Territorial, este plan se presenta con las siguientes palabras: "No se trata de desregular, ni de dejar desprotegidos los intereses de los trabajadores, de los consumidores u otros intereses públicos. No se trata de regular menos, sino de regular mejor, más eficientemente, y de proporcionar un mejor servicio. De este modo vamos a hacer más rápidas y livianas, y también menos costosas, las gestiones administrativas asociadas a la creación y funcionamiento de las empresas y a la actividad de profesionales, trabajadores autónomos y ciudadanos en general.”. La Mejora Regulatoria implica la creación de un marco regulador de calidad que contribuya al crecimiento económico, al empleo y a la productividad, a través de la reducción de los costes innecesarios y eliminación de obstáculos. Por sus efectos sobre la productividad 
La definición que da la BERR ${ }^{136}$ de gravámenes administrativos innecesarios (burdens) es la siguiente:

- Los que resultan desproporcionados con el objetivo de la actuación administrativa prevista, es decir, que va más allá de lo necesario para conseguir dicho objetivo;

- Los que están previstos para situaciones en que no hace falta esa actividad administrativa para conseguir ese objetivo;

- o que son impuestos en circunstancias y casos en los que es posible satisfacer ese objetivo público de otra forma menos gravosa ${ }^{137}$.

Aunque particularmente creo más reveladora la definición que da el propio Gobierno en uno de sus informes de su política Regulatory Reform Program: "requisitos que se pide a cualquier organización para demostrar que cumple con la normativa, como rellenar formularios, someterse a inspecciones, completar informes, cooperar con auditorías, rellenar solicitudes para solicitar becas y ayudas, licencias o autorizaciones o para solicitar exenciones, formularios de quejas y recursos, registros, etc.”138.

y la competitividad, la Mejora Regulatoria, conecta de pleno con los objetivos del Plan de Lisboa 2001,0 Estrategia Renovada de Lisboa,esto es, hacer de la Unión Europea la economía más competitiva del mundo.

La Mejorade la Regulaciónse refiere tantoa la calidad de las leyes como a la calidad de la intervención administrativa, racionalizando ésta y ajustándola a lo necesario para garantizar la protección de los intereses generales. Impone varios deberes:

La medición y Reducción de las Cargas Administrativas: la Medición y Reducción de las Cargas Administrativases uno de los puntos en los que más se está trabajando en la política de MejoraRegulatoria porque la actividad de las Administraciones Públicas tiene una incidencia inmediata en las actividades privadas y de ahí en el crecimiento económico y generación de empleo. Por este motivo la simplificación administrativa, la reducción de barreras y cargas, ha entrado en la llamada "agenda política". La carga administrativa son los costes que soportan las empresas como consecuencia de una obligación contenida en la norma, de tal forma que las empresas dejarían de realizar dicha actividad si la norma desapareciera.

El análisis de Impacto Normativo: el Análisis de ImpactoNormativo supone realizar un estudio riguroso de las consecuencias de aplicar una determinada regulación, así como las posibles alternativas a esa norma y las consecuencias económicas derivadas de la aplicación.

La participación de la sociedad civil: la participación de la sociedad civil es un elemento fundamental para la Mejora Regulatoria ya que permite mejorar la calidad de la legislación y su adecuación a las necesidades sociales.

La simplificación normativa: la simplificación normativa supone la revisión sistemática de la regulación, desde la simplificación a la codificación, esto es reunir en un mismo texto las normas relativas a una sola materia.

La calidad formal de las normas: la calidad formal de las normas supone quela norma debe estar escrita en términos claros y precisos, accesibles al ciudadano.

Es importante reseñar que, hasta ahora, en España no se ha unido la idea de reducción de las cargas administrativas y el ejercicio de la potestad sancionadora, como sí ha pasado con la RESA en el Reino Unido.

136 Cfr. BERR (2008), DEPARTMENT FOR BUSINESS ENTERPRISE AND REGULATORY REFORM, Im pact Assessment... opus cit., mayo de 2008, p. 49.

137 Como ejemplo de gravamen innecesario podría ponerse la obligación impuesta por una Agencia o Administración de exigir un determinado tipo de tecnología a una empresa, cuando sea cierto que existe otra tecnología menos cara y accesible que consigue idénticos resultados.

138 Cfr. H.M. Government (2007): Cutting burocracy... opus cit., p. 14. Este Informe recopila las medidas más importantes emprendidas por el Gobierno para simplificar procedimientos administrativos, tanto para las PIMES como para el tercer sector y para los administrados en general. 
Para salvaguardar la soberanía del Parlamento, se entiende que nunca podrá ser considerado como gravamen innecesario el que haya sido impuesto directamente por una ley, sin que medie en su regulación y/o imposición ninguna discrecionalidad administrativa.

La política de reducción de gravámenes administrativos innecesarios forma parte esencial de la "Better Regulation Agenda" del Gobierno laborista, hasta el punto de que el actual Primer Ministro, Gordon Brown, la ha adoptado como uno de sus estandartes de la presente legislatura. Para ello el Gobierno está adoptando más de 500 medidas de simplificación administrativa en sus 19 ministerios, con el objetivo ya comentado de ahorrar hasta 3,4 billones de libras a finales de $2010^{139}$. Algunas de ellas, bastante extremas a mi juicio, consisten en reducir o derogar la normativa innecesaria, reemplazarla por códigos voluntarios de buenas prácticas o eximir a determinados grupos de empresas, por ejemplo las PIMES, del cumplimiento de determinados requisitos ${ }^{140}$.

\section{2. Ámbito subjetivo de la obligación de reducir, eliminar o revisar gravámenes administrativos innecesarios}

La RESA, en su art. 73.2, impone este deber a las Agencias de gas y electricidad, de Comercio, de Ferrocarriles, de Servicios postales y del Agua, si bien pretende que, en un futuro próximo se incorporen más Agencias y organismos públicos, una vez que el Ministerio haya consultado con los mismos. La ampliación de ese deber a nuevas Agencias u organismos requiere un statutory instrument ${ }^{141}$, normalmente una Orden, aprobada por las dos Cámaras del Parlamento, cuyo proyecto debe ser elaborado por el Ministerio competente (el del ramo o, cuando sea apropiado, el Ministro responsable de la política de Better Regulation), y en la que debe concretarse a qué regulatory functions se aplica ese deber. La Orden ministerial original podría ser dero-

La misma normativa, cuando es innecesaria, se ve como un burden. Para evitarlo, el propio Gobierno ha instaurado una evaluación de impacto de cada reglamento que se apruebe (impact assessment), de modo parecido pero más profundo y serio que el un informe sobre la necesidad y oportunidad de las disposiciones administrativas previsto en el art. 24.1.a) de nuestra Ley del Gobierno.

139 La intención final es mantener el status del Reino Unido como uno de los lugares donde más fácilmente se hacne negocios del mundo, expresión textual del Gobierno. El Banco Mundial coloca al Reino Unido en la sexta posición mundial a este respecto. Cfr. H.M. Government, Making your live simpler. Opus cit., p. 8. Según el propio Gobierno, la política de reforma normativa actual del Reino Unido es actualmente la más ambiciosa a nivel mundial.

140 BETTER REGULATION EXECUTIVE, Administrative Burdens - Routes to Reduction, septiembre de 2006, p. 10.

141 Un statutory instrument es un reglamento de desarrollo o ejecutivo de una Ley previa. En el Reino Unido estos reglamentos deben ser comunicados al Parlamento y, en algunos casos importantes, en los que se atribuyen potestades y deberes, deben ser aprobados por el mismo, aunque eso no los convierte en leyes. Ocurre algo parecido con algunos planes de ordenación del territorio autonómicos en España. Los statutory instruments suelen ser Orders, Regulations, Rules, Directions, u Orders of Local Authorities. En la Parte Cuarta de la RESA normalmente los Ministros imponen el deber de reducir, eliminar o revisar gravámenes administrativos innecesarios mediante Orden. 
gada o reformada por otra Orden ministerial posterior, que podría revocar ese deber o modificar su alcance.

Normalmente, ese deber no tiene caducidad, ya que se impone sine die a las Agencias afectadas, salvo que se diga lo contrario y expresamente se imponga un plazo determinado para su ejercicio.

La reducción, revisión o eliminación de gravámenes innecesarios puede hacerse también de manera voluntaria por cualquier Administración, y suele acarrear obligaciones accesorias como las de simplificación administrativa o redacción más inteligible de los mismos: normalmente la Agencia debe reenviar a los sujetos afectados por esos gravámenes un folleto explicativo y resumido explicando de manera llana lo que se pretende de ellos en relación con una concreta actividad administrativa ${ }^{142}$.

La reducción o eliminación de gravámenes administrativos innecesarios puede producirse también a nivel reglamentario. El Gobierno y las Agencias, a la hora de aprobar nuevos reglamentos, debe someterlos a información pública para que los agentes regulados, entre otras cosas, indiquen campos en los que podría simplificarse la actividad administrativa y reducirse los gravámenes impuestos, hasta convertirse en un principio básico, permanente y rutinario de la misma ${ }^{143}$, de forma que su actividad administrativa se someta de manera permanente a una revisión de proporcionalidad (risk-assessment) entre los gravámenes impuestos y los beneficios que de ellos se derivan para el bien común. Ahora bien, ante el riesgo que supondría que este deber de revisión y de simplificación pueda acabar eliminando el margen de discrecionalidad del que disponen las Administraciones de manera legítima y adecuada, debe quedar claro que no se impone a cualquier Administración (como se ha dicho) ni, dentro de cada una de ellas, a cualquier actividad, sino a las concretadas por orden ministerial, por haberse identificados como mejorables.

142 Así, verbigracia, la Agencia Medioambiental inglesa publicó un resumen de 5 páginas de las 75 de que constaba su política de residuos derivados de la agricultura y ganadería. Y el Ministerio de Transporte mejoró su sistema de inspección técnica de la seguridad de vehículos de transporte de mercancías y de viajeros, reduciendo el número de veces que esos vehículos debían pasar la inspección a dos anuales, bajando también el coste de las mismas. Y también merece la pena recordar la experiencia de la Agencia de salud y Seguridad, que ha reducido sus impresos un $54 \%$, lo que ha supuesto un importante abaratamiento de costes y de trabajo para las empresas y negocios. Cfr. BERR (2008), DEPARTMENT FOR BUSINESS ENTERPRISE AND REGULATORY REFORM, Impact Assessment... opus cit., mayo de 2008, p. 50.

143 EL Gobierno británico ha creado incluso una web (betterregulation.gov.uk) en la que cualquier empresa o ciudadano puede dar su opinión sobre cómo podría simplificarse y reducirse las cargas administrativas (onus) existentes en la regulación que le afecta, comprometiéndose el Gobierno a publicar una respuesta a las mismas en un plazo máximo de 90 días. Bajo el eufemístico eslogan de "Life's too short to be bogged down by rules and regulations", pueden consultarse cientos de ideas enviadas desde el sector privado, el sector público o el tercer sector (ONGs, caridad) que van desde lo más peregrino (la forma de cuidar de la higiene a la hora de comer en la empresa) hasta las novedades más dogmáticas sobre Administración local, empleo público o servicios públicos. La efervescencia de ideas recogidas y la seriedad y tamaño de las respuestas oficiales da buena prueba de la buena salud de que goza la Democra162 los asuntos públicos. 
Los criterios que debería examinar el Gobierno antes de imponer ese deber a una determinada Agencia son los siguientes:

- El impacto que haya tenido en la misma el Regulators'Compliance Code;

- la opinión de los administrados,

- la opinión de la propia Agenda, a la que se escucha en un audiencia previa,

- la carga total de gravámenes administrativos impuestos al sector

- los informes recaídos por parte de los Select Commitees, National Audit Office, Audit Commission y otras organizaciones públicas o privadas, y

- la opinión de la LBRO.

Como ya se ha dicho, antes de que el Ministro imponga ese deber a una Agencia, debe escuchar a todas las partes implicadas, y lo ideal sería que todas ellas llegaran a un acuerdo a través del Panel for Regulatory Accountability (PRA), un órgano administrativo ad hoc.

El mecanismo que usa la Agencia para detectar gravámenes administrativos innecesarios es una revisión (review) por sí misma de los que hubiese aprobado a nivel reglamentario, de instrucciones o guías, y de potestad sancionadora. Además, en un plazo establecido en la Orden ministerial que impone el deber, normalmente cada año, la Agencia debe emitir un informe (report) sobre los que hubiese detectado, las acciones que ha tomado para reducirlos, revisarlos o eliminarlos, o, si aún no lo hubiera hecho, el plazo y calendario (timetable) previsible para ello. Ni qué decir tiene que la primera revisión que hiciese la Agencia una vez impuesto por el Gobierno el deber de auto revisarse será la más profunda y la que más acciones adopte. Una vez pasada la primera revisión, la Agencia debe seguir revisando su actividad administrativa anualmente, revisión que quedará plasmada en cada Informe anual, si bien es lógico pensar que en éstos cada vez se encontrarán menos gravámenes administrativos innecesarios.

De todas formas, si algún interesado pensara que una Agencia no ha cumplido suficientemente con su deber de reducir los gravámenes administrativos innecesarios, podría plantearse demandarla. A ello la Agencia puede oponer el principio de proporcionalidad, es decir, que aunque ha encontrado determinados gravámenes innecesarios, el costo de su eliminación o reducción superaría los beneficios que ello supondría para el sector regulado; también puede alegar que se trata de gravámenes impuestos por leyes, cuya derogación o modificación no le compete ni a la Agencia ni al Gobierno. Estas razones para no eliminar los gravámenes innecesarios detectados deben también incluirse en el informe anual emitido por la Agencia ${ }^{144}$.

144 Evidentemente, la política de simplificación administrativa y de reducción de gravámenes administrativos innecesarios no puede aplicarse con efectos retroactivos a actos administrativos o casos ya 
La Parte Cuarta de la RESA se aplica plenamente a todas las regulatory functions existentes en Inglaterra y Gales. En Escocia, sólo se aplica a determinadas materias reservadas, y en Irlanda del Norte a las materias que hayan sido transferidas.

\section{Acciones a adoptar}

Las acciones principales previstas en el Plan británico de reducción de gravámenes administrativos innecesarios (algunas de ellas copiadas por el Plan español de reducción de cargas administrativas) son:

- Reducir en un 30\% las cargas soportadas por las empresas derivadas de la legislación nacional para el año 2012;

- adoptar el Modelo de Costes Estándar (SCM) como método para medir las cargas administrativas;

- realizar un Proyecto Piloto que permita evaluar el ahorro de costes que supondrá el Programa de Reducción de Cargas Administrativas.

Para ello, las Agencias relacionadas en la RESA (art. 75) deben dar a conocer un Informe anual (report o statement), en el que se explique la actividad realizada para reducir los gravámenes administrativos innecesarios, aunque los Ministros pueden imponer este deber o cometido (duty) a otras Agencias, o extenderlo a otros asuntos, aunque no pueden dar órdenes e instrucciones a las Agencias para que remuevan un determinado gravamen administrativo, ya que deben ser ellas mismas las que, tras revisar su actuación administrativa, procedan a reducir, eliminar o revisar esos gravámenes, cuando tengan competencia para hacerlo y haya proporción entre los costes y las ganancias que ello acarrearía para el interés público (art. 72).

\section{CONCLUSIONES}

Una vez analizada la RESA, al jurista español le queda un regusto agridulce: por una parte, no puede dejar de sonreír ante la ingenuidad y juventud de este recién creado Derecho administrativo sancionador británico, plasmado en esta Ley, que revela un cambio de mentalidad trascendental en UK sobre las relaciones entre los Poderes Públicos y los ciudadanos: la batalla entre Common Law y el Derecho Administrativo por encumbrarse como el Derecho normal y común de las Administraciones británicas está empezando a ser ganada por éste. Pero la sonrisa se tuerce cuando uno repara en la forma en que ha sido configurada esa potestad sancionadora en la

164 cerrados, ni tampoco al derecho de la competencia, pues podría distorsionarla y colocar a algunas empresas beneficiadas de esas medidas en una posición de ventaja en relación con otras no beneficiadas. 
RESA, a la vista de la enorme discrecionalidad que la Ley otorga a las Órdenes ministeriales encargadas de atribuir la potestad reglamentaria a las Agencias estatales y locales.

Es cierto que esa discrecionalidad permite al Ministro poder vestir con un traje propio a cada Agencia, accediendo a permitir el uso de uno u otro tipo de las sanciones administrativas previstas en la Ley, pero no lo es menos que la RESA sólo impone unas garantías de tipo procedimental mínimas para su uso, dejando en manos del Ministro el desarrollo de procedimientos propios y la delimitación de las sanciones, para cada Agencia en concreto. Las garantías procesales profundas y el reconocimiento de los derechos humanos queda instaurada, desde fuera, con la erección de una especie de jurisdicción contencioso-administrativa general (con la creación del First-tier Tribunal, el Upper Tribunal y la Supreme Court), que acaba de echar a andar, y con la traslación, por analogía, del CEDH a los procedimientos sancionadores.

La Ley es bienintencionada y no cabe negarle una enorme vocación innovadora: crear un elenco de sanciones administrativas flexibles y poco formalistas como alternativa mejorada a las sanciones penales, en un imparable proceso de reordenación del ius puniendi a la manera convencional: la potestad sancionadora funciona como mecanismo de reacción ordinario de las Administraciones frente a las infracciones de la norma, y el Derecho penal queda relegado a su papel secular de ultima ratio, por gravedad o reincidencia, de esa actividad represiva, cuando, hasta hace bien poco, mantenía un papel estelar. Y lo hace sin ambages, echando la imaginación a volar y creando sanciones del todo novedosas para nosotros, que incluyen requerimientos de todo tipo, envío de cartas y advertencias, órdenes de “cesación” o de acción, e incluso la posibilidad de pactar la responsabilidad administrativa del administrado y la sanción a imponer, nada menos.

Pero, fundamentalmente, nos cabe un escrúpulo de fondo, que hemos ido rumiando a lo largo de esta investigación, y es que, a nuestro juicio, la potestad sancionadora no debería integrarse, como ocurre en el Reino Unido, dentro de planes encaminados a reducir las exigencias de interés público que pesan sobre el mundo empresarial, haciéndola equivaler a veces, de manera equivocada y un tanto peyorativa, a burocracia; ni debe ser susceptible de integrarse en la política de reducción de gravámenes administrativos innecesarios (la Better Regulation Agenda), pues se basa en unos principios irrenunciables de predecibilidad, igualdad y seguridad jurídica, que quedan seriamente comprometidos con los objetivos de intervención mínima y flexibilidad enunciados en aquélla.

Otro extremo criticable de la Ley es su obsesión por la competitividad empresarial: la RESA nunca habla de personas físicas como posibles destinatarias de las políticas de intervención administrativa y de ejecución normativa (dentro de la cual se inserta, como se ha dicho, la potestad sancionadora), lo que le otorga un enfoque innegablemente sesgado hacia el sector económico. Con ello se consigue correr un velo de sospecha sobre todo lo que huela a gravamen o a actividad de policía, so pre- 
texto de entorpecer el libre desenvolvimiento de los negocios. Desde la óptica del jurista persa (el español, en este caso), la actuación administrativa no debería distinguir entre personas físicas y jurídicas, porque supondría romper el principio de igualdad y crear un condicionamiento económico de la actividad administrativa, que, en principio, debe estar presidida por la búsqueda de los intereses generales (de todo tipo, no sólo aquéllos que se miden por una ventaja económica). Todo ello queda justificado en la ley en aras de la libertad y la competencia, que nunca deberían estar enfrentadas, en puridad, a la actividad administrativa.

Sea bienvenida, pues, esta Ley, como acercamiento del Reino Unido al régime administratif de la potestad sancionadora, aunque lleve instilado, en la masa de su sangre, paradójicamente, el germen de la divergencia.

\section{BIBLIOGRAFÍA}

ADMINISTRATIVE JUSTICE AND TRIBUNALS COUNCIL, Annual Report 2007/2008.

Alder, J. (1989), Constitutional and Administrative Law, McMillan, Londres.

AUSTRALIAN GOVERNMENT (2006), Rethinking Regulation. Report of the Taskforce on Reducing Regulatory Burdens on Business, enero 2006.

AUSTRALIAN LAW REFORM COMMISSION (2000), Securing Compliance: Civil and Administrative Penalties in Federal Regulatiom.

Bailey, S. H., Jones B. L., y Mowbray, A. R. (1992), Cases and materials on Administrative Law, Sweet and Maxwell, segunda edición, Londres.

BERR (2007), DEPARTMENT FOR BUSINESS ENTERPRISE AND REGULATORY REFORM, Government response to the consultation on the statutory instruments under the regulatory enforcement and sanctions act 2008, marzo 2009.

- Impact Assessment: the Regulatory Enforcement and Sanctions Bill, mayo de 2008, Londres.

- Regulators' Compliance Code (Statutory Code of Practice for Regulators), 17 de diciembre de 2007.

- Regulatory Enforcement and Sanctions Act. Consultation on the Primary Authority Scheme, septiembre de 2008.

- Regulatory Sanctions Act 2008, Guidance to the Act, julio 2008.

Betancor, A (2009), “Derecho Administrativo sancionador en el sistema jurídico británico: Regulatory Enforcement and Sanctions Act 2008”, RGDA, 19.

BETTER REGULATION EXECUTIVE (2006), Administrative Burdens - Routes to Reduction, septiembre de 2006.

Craig, P. P. (1994), Administrative Law, Sweet \& Maxwell, tercera edición, Londres.

DEPARTMENT OF CONSTITUCIONAL AFFAIRS, JUSTICE, RIGHTS AND DEMOCRACY (2006), A Guide to the Human Rights Act 1998, Third Edition, octubre de 2006.

Fitz Gerald, R. (2005), Administrative Justice and Inter-Ministerial Communication Within Public Administration, Trieste, marzo 2005

García de Enterría, E. y Fernández Rodríguez, T. M. (1998), Curso de Derecho Adminis166 trativo, Tomo I, Editorial Civitas, S.A., Madrid, octava edición. 
Hawke, N. y Parpwoth, N. (1996), Introduction to Administrative Law, Cavendish Publishing Limited, Londres.

H.M. Government (2007): Cutting burocracy for our public services, junio 2007.

- Annual Review 2008, Making it simple, Londres, 2008..

- Making your live simpler. Simplifications plans. A summary, 2008.

LAW REFORM COMMISSION OF CANADA (1976), Our Criminal Law, 4, Information Canada, Ottawa.

LBRO (2008), Confidence and Consistency: The basics and benefits of the Primary Authority scheme.

- Primary Authority Guidance, 2009.

MINISTRY OF JUSTICE (2009), Guidance on creating new regulatory penalties and offences, 26 de enero de 2009.

OF LAIRGH, LORD IRVINE (2003), Human Rights, Constitutional Law, and the development of the english legal system, Hart Publishing, Portland, Oregon.

Poole, T (2007), "The reformation of English Administrative Law”, en Law Society Economy Working Papers, 12/2007, Londres.

RISK AND REGULATION ADVISORY COUNCIL (2009), Response with responsibility. Policy-making for public risk in the 21st century, mayo 2009

Sánchez Sáez, A. J. (2005), Los convenios de colaboración para la protección del medio ambiente, IAAP, Sevilla.

- "Reflexiones sobre la Resolución Alternativa de Conflictos administrativos en los Estados Unidos de América: su virtualidad en el Derecho Ambiental”, en la obra colectiva, coordinada por Carmen Carretero Espinosa de los Monteros, Alternativas no jurisdiccionales en la Resolución de Pretensiones de Derecho Público, VI Jornadas de Estudio del Gabinete Jurídico de la Junta de Andalucía, IAAP-Consejería de Justicia y Administración Pública-Consejería de la Presidencia, Sevilla.

Soto Kloss, E. (1973), “¿Existe un Derecho Administrativo inglés?”, en Revista de administración pública, $\mathrm{N}^{\circ} 70$.

Villar Palasí, J. L. (1959), “La Federal Administrative Procedure Act de Estados Unidos", RAP, n. ${ }^{\circ} 1$.

Wade, W. y Forsyth, C. (2000), Administrative Law, octava edición, Oxford University Press, Oxford.

Walker, D. (1980), The Oxford Companion to Law, Clarendon Press, Oxford. 
